\title{
Online-coupled meteorology and chemistry models: history, current status, and outlook
}

\author{
Y. Zhang ${ }^{1}$ \\ ${ }^{1}$ North Carolina State University, Raleigh, NC 27695, USA \\ Received: 17 October 2007 - Published in Atmos. Chem. Phys. Discuss.: 4 February 2008 \\ Revised: 10 April 2008 - Accepted: 13 May 2008 - Published: 10 June 2008
}

\begin{abstract}
The climate-chemistry-aerosol-cloud-radiation feedbacks are important processes occurring in the atmosphere. Accurately simulating those feedbacks requires fully-coupled meteorology, climate, and chemistry models and presents significant challenges in terms of both scientific understanding and computational demand. This paper reviews the history and current status of the development and application of online-coupled meteorology and chemistry models, with a focus on five representative models developed in the US including GATOR-GCMOM, WRF/Chem, CAM3, MIRAGE, and Caltech unified GCM. These models represent the current status and/or the state-of-the science treatments of online-coupled models worldwide. Their major model features, typical applications, and physical/chemical treatments are compared with a focus on model treatments of aerosol and cloud microphysics and aerosol-cloud interactions. Aerosol feedbacks to planetary boundary layer meteorology and aerosol indirect effects are illustrated with case studies for some of these models. Future research needs for model development, improvement, application, as well as major challenges for online-coupled models are discussed.
\end{abstract}

\section{Introduction}

The climate-chemistry-aerosol-cloud-radiation feedbacks are important in the context of many areas including climate modeling, air quality/atmospheric chemistry modeling, numerical weather and air quality forecasting, as well

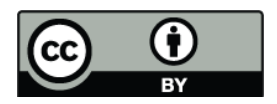

Correspondence to: Y. Zhang

(yang_zhang@ncsu.edu) as integrated atmospheric-ocean-land surface modeling at all scales. Some potential impacts of aerosol feedbacks include a reduction of downward solar radiation (direct effect); a decrease in surface temperature and wind speed but an increase in relative humidity (RH) and atmospheric stability (semi-direct effect), a decrease in cloud drop size but an increase in drop number via serving as cloud condensation nuclei (CCN) (first indirect effect), as well as an increase in liquid water content, cloud cover, and lifetime of low level clouds but a suppression or enhancement of precipitation (the second indirect effect). Aerosol feedbacks are traditionally neglected in meteorology and air quality modeling due largely to historical separation of meteorology, climate, and air quality communities as well as our limited understanding of underlying mechanisms. Those feedbacks, however, are important as models accounting (e.g., Jacobson, 2002; Chung and Seinfeld, 2005) or not accounting (e.g., Penner et al., 2003) for those feedbacks may give different results (Penner, 2003; Feichter et al., 2003; Jacobson, 2003a, b) and future climate changes may be affected by improved air quality and vice versa through various feedback mechanisms (Brasseur and Roeckner, 2005; Jacobson, 2002). Increasing evidence from field measurements have shown that such feedbacks ubiquitously exist among the Earth systems including the atmosphere, hydrosphere, lithosphere, pedosphere, and biosphere. For example, a stratocumulus cloud layer just below the advected pollutant layer observed during the 1993 North Atlantic Regional Experiment (NARE) was found to increase pollutant concentrations through the enhancement of the photolytic rates and oxidant levels (Audiffren et al., 2004). Satellite observations have shown that smoke from rain forest fires in tropical areas such as Amazon and Indonesia (Kaufman and Fraser, 1997; Rosenfeld and

Published by Copernicus Publications on behalf of the European Geosciences Union. 
Lensky, 1998; Rosenfeld, 1999) and burning of agricultural vegetations (Warner, 1968; Rosenfeld and Woodley, 1999) can inhibit rainfall by shutting off warm rain-forming processes. This effect is due to the fact that large concentrations of small $\mathrm{CCN}$ in the smoke from biomass burning lead to the formation of many small cloud droplets, thus inhibiting cloud droplet coalescence into raindrops and riming on ice precipitation (Rosenfeld, 2000). While the suppression of rain and snow by urban and industrial air pollution has been reported (Rosenfeld, 2000; Givati and Rosenfeld, 2004, 2005), enhanced rainfall, on the other hand, was also found downwind of urban areas or large sources such as paper mills (Eagen et al., 1974; Jauregui and Romales, 1996) and over major urban areas (Braham et al., 1981; Cerveny and Bailing, 1998), suggesting that giant $\mathrm{CCN}$ can enhance precipitation.

Although significant progress has been made in modeling climate, meteorology, air pollution in the past several decades (Seaman, 2000; Seinfeld, 2004; Seigneur, 2005), several major deficiencies exist in most current global climate-aerosol models (e.g., Johnson et al., 1999, 2001; Mickley et al., 2004; Langner et al., 2005; Sanderson et al., 2006) that are developed either based on a general circulation model (GCM) or a global chemical transport model. First, the coarse spatial resolution (e.g., $\left.4^{\circ} \times 5^{\circ}\right)$ used in those models cannot explicitly capture the fine-scale structure that characterizes climatic changes (e.g., clouds, precipitation, mesoscale circulation, sub-grid convective system, etc.). Second, the coarse time resolution (e.g., 6-h average wind field) used in those models (except for a few models that use a smaller time step, e.g., GATOR-GCMOM typically updates meteorology every 5 minutes) cannot replicate variations at smaller scales (e.g., hourly and diurnal). Third, those models typically use simplified treatments (e.g., simple meteorological schemes and chemistry/aerosol microphysics treatments) that cannot represent intricate relationships among meteorology/climate/air quality variables. Fourth, most models simulate climate and aerosols offline with inconsistencies in transport and no climate-chemistryaerosol-cloud-radiation feedbacks (e.g., Prather et al., 2003; Sanderson et al., 2006). At present, most global air quality models (GAQMs) are still offline. An empirical sulfate$\mathrm{CCN}$ relation for aerosol indirect effects is typically used in most GAQMs. Some feedbacks are accounted for in some global climate/chemistry models (e.g., Lohmann and Feichter, 1997; Chuang et al., 1997, 2002; Ghan et al., 2001a, b, c; Nagashima et al., 2002; Steil et al., 2003; Hauglustaine et al., 2004; Liao and Seinfeld, 2005) but either with simplified treatments or at a coarse resolution or both. Most air quality models at urban/regional scales, on the other hand, use offline meteorological fields without feedbacks and do not simulate aerosol direct and indirect effects (e.g., the EPA's Community Multiple Air Quality (CMAQ) modeling system, Byun and Ching, 1999; Binkowski and Roselle, 2003). Some urban/regional air quality models are driven by a global model with inconsistent model physics (e.g., Lang- mann et al., 2003; Hogrefe et al., 2004; Tulet et al., 2005; Sanderson et al., 2006). Most regional climate models use prescribed aerosols or simple modules without detailed gasphase chemistry, aerosol microphysics, and aerosol-cloud interactions (e.g., Giorgi et al., 1993 a, b; Giorgi and Shields, 1999). The aforementioned model deficiencies in accurately representing atmospheric processes and feedbacks have led to the largest uncertainties in current estimates of direct and indirect effects of aerosols on climate (IPCC, 2001; 2007) as well as the impact of climate on air quality. Accurately simulating those feedbacks requires fully-coupled models for meteorological, chemical, physical, and biological processes and presents significant challenges in terms of both scientific understanding and computational demand. In this work, the history and current status of development and application of online-coupled models worldwide are reviewed in Sect. 2. Several representative online-coupled meteorology and chemistry models developed in the US are used to illustrate the current status of online-coupled models in Sect. 3. Their major model features, typical applications, and physi$\mathrm{cal} / \mathrm{chemical}$ treatments are compared with a focus on aerosol and cloud microphysics treatments and aerosol-cloud interactions. Simulated aerosol feedbacks to planetary boundary layer meteorology and aerosol indirect effects are illustrated with case studies for some of these models in Sect. 4. Major challenges and recommendations for future needs for the development, improvement, and application of online-coupled models are discussed in Sect. 5.

\section{History of online-coupled climate/meteorology and air quality modeling}

\subsection{Concepts, history, and milestones of online- coupled models}

Atmospheric chemistry or air quality and climate or meteorology modeling were traditionally separated prior to 1970's. The three-dimensional (3-D) chemical transport models (CTMs) until that time were driven by either measured/analyzed meteorological or chemical fields at a time resolution of 1-6 h from a mesoscale meteorological model on urban/regional scale or outputs at a much coarser time resolution (e.g., 6-h or longer) from a GCM (referred to as offline coupling). In addition to a large amount of data exchange, this offline separation does not permit simulations of feedbacks between air quality and climate/meteorology and may result in an incompatible and inconsistent coupling between both meteorological and air quality models and a loss of important process information (e.g., cloud formation and precipitation) that occur at a time scale smaller than that of the outputs from the offline climate/meteorology models (Seaman, 2000; Grell et al., 2005; Baklanov and Korsholm, 2007). Such feedbacks, on the other hand, can be 
simulated in fully-coupled online models, without space and time interpolation of meteorological fields but commonly with higher computational costs.

Both offline and online models are actively used in current regional and global models. Offline models are frequently used in ensembles and operational forecasting, inverse/adjoint modeling, and sensitivity simulations, whereas online models are increasingly used for applications in which the feedbacks become important (e.g., locations with high frequencies of clouds and large aerosol loadings), the local scale wind and circulation system change quickly, and the coupled meteorology-air quality modeling is essential for accurate model simulations (e.g., real-time operational forecasting or simulating the impact of future climate change on air quality). Reported differences in simulation results from online and offline models can be fairly small or quite significant, depending on the level of complexities of the model treatments and the simulated variables. For example, Mickley et al. (1999) found that differences in the simulated radiative forcing of anthropogenic ozone $\left(\mathrm{O}_{3}\right)$ from their global chemistry-climate model operated online and offline are within $2 \%$. While their online radiation calculation was carried out every 5 -hr based on the $\mathrm{O}_{3}$ fields simulated by a detailed tropospheric $\mathrm{O}_{3}-\mathrm{NO}_{\mathrm{x}}$-hydrocarbon chemistry and did not account for the radiation feedbacks into the climate calculation, their offline radiation calculation was based on the monthly-mean $\mathrm{O}_{3}$ fields. Shindell et al. (2001) found that the tropospheric oxidation capacity in terms of hydroxyl radical $(\mathrm{OH})$ simulated by their online model is lower by $\sim 10 \%$ than that of the same model but running offline. Jacobson (2002) and Chung and Seinfeld (2005) reported a positive forcing of fossil-fuel black carbon (BC) and organic matter using their online-coupled models, whereas other models that do not account for aerosol feedbacks and use a different mixing state treatment for $\mathrm{BC}$ give a strong negative forcing (e.g., Penner et al., 2003). Nevertheless, there is an increasing recognition from science communities that onlinecoupled model systems represent the true, one atmosphere and are urgently needed, although there remain significant work for such models to be mature and their applications are currently limited by computational constraints.

Regardless of the temporal and spatial scales of applications, online-coupled models provide powerful platforms for reproducing the feedbacks among multiple processes and variables in varying degrees in one-atmosphere, depending on the framework and degree of the coupling enabled in those models. Two coupling frameworks are conventionally used in all mesoscale and global online-coupled models: one couples a meteorology model with an air quality model in which the two systems operate separately but exchange information every time step through an interface (referred to as separate online coupling), the other integrates an air quality model into a meteorology model as a unified model system in which meteorology and air quality variables are simulated together in one time step without an interface between the two models (referred to as unified online coupling). In models with a unified online coupling, the equations can be solved simultaneously with a nonlinear equation solver or the meteorological and air quality processes can be solved using operator splitting; the latter is more often used at present. The main difference between the two types of coupling is that the transport of meteorological and chemical variables is typically simulated with separate schemes in separate online models but the same scheme in unified online models. Depending on the objectives of the applications, the degrees of coupling and complexities in coupled atmospheric processes in those models vary, ranging from a simple coupling of meteorology and gas-phase chemistry (e.g., Rasch et al., 1995; Grell et al., 2000; Langmann, 2000) sophisticated coupling of meteorology, chemistry, aerosol, radiation, and cloud (e.g., Jacobson, 1994, 2004b, 2006a; Grell et al., 2002, 2005). While online-coupled models can in theory enable a full range of feedbacks among major components and processes, the degree of coupling in those models varies substantially from slightly-coupled to moderately- or significantly-, or fullycoupled. In the slightly- or moderately-coupled models, only selected species other than water vapor (e.g., $\mathrm{O}_{3}$ or aerosols) and/or processes (e.g., transport of chemical species other than water vapor or gas-phase chemistry) are coupled and other processes (e.g., solar absorption of $\mathrm{O}_{3}$ and total radiation budget) remain decoupled. Feedbacks among processes may or may not be accounted for. In the significantly- or fully-coupled models, major processes are coupled and a full range of atmospheric feedbacks are realistically simulated. At present, very few significantly- or fully-coupled online models exist. Most online models are still under development; they are slightly- or moderately-coupled with little or no feedbacks among major atmospheric processes. Depending on the coupled components/processes, those online models can be generally grouped into four main categories: online meteorology and pollutant transport; online meteorology and pollutant transport and chemistry; online pollutant feedbacks to heating rates to drive meteorology; and online pollutant feedbacks to photolysis to drive photochemistry. Examples of each category are given in Table 1; they represent various degrees of coupled treatments for each category, varying from highly-simplified to the most sophisticated one.

While a large number of online-coupled global climatechemistry GCMs have been developed for simulating global climate change and air quality studies for more than three decades, there exist fewer coupled meteorology(or climate-) chemistry models at urban and regional scales. This is largely due to the historic fact that mesoscale meteorology models and air pollution models were developed separately. The development of mesoscale coupled meteorologychemistry models was driven by the needs for forecasting air quality in real-time and simulating feedbacks between air quality and regional climate as well as responses of air quality to changes in future regional climate, land use, and biogenic emissions. Figure 1 shows chronology 
Table 1. Examples of treatments of online coupling of gas, aerosol, radiative, transport, and meteorological processes.

\begin{tabular}{|c|c|c|c|c|c|c|c|c|c|c|c|c|c|c|}
\hline & H69 & $\begin{array}{l}\text { C70, } \\
\text { S79 }\end{array}$ & $\mathrm{C} 75$ & $\begin{array}{l}\text { A75, } \\
\text { Jo76 } \\
\text { T85, } \\
\text { C85, } \\
\text { M86 }\end{array}$ & $\begin{array}{l}\text { P84,C } \\
\text { R95 } \\
\text { L00 }\end{array}$ & & $\mathrm{P} 92$ & $\begin{array}{l}\mathrm{J} 94, \\
\mathrm{~J} 95, \\
\mathrm{~J} 96, \\
\text { J97a, } \\
\text { J97b }\end{array}$ & $\begin{array}{l}\text { J02, } \\
\text { J04a- } \\
\text { d }\end{array}$ & G05 & $\begin{array}{l}\text { J06 } \\
\text { J07 }\end{array}$ & F06 & L08 & Jö06 \\
\hline \multicolumn{15}{|c|}{ Online meteorology and pollutant transport } \\
\hline $\mathrm{O}_{3}$ & $\mathrm{Y}$ & $\mathrm{Y}$ & & & & & $\mathrm{Y}$ & & & & & & & \\
\hline $\mathrm{O}_{3}$ and some other gases and families & & & & & $\mathrm{Y}$ & $\mathrm{Y}$ & & & & $\mathrm{Y}$ & & $\mathrm{Y}$ & & $\mathrm{Y}$ \\
\hline All photochemically-active gases & & & & & & & & $\mathrm{Y}$ & $\mathrm{Y}$ & & $\mathrm{Y}$ & & & \\
\hline Single bulk or modal aerosol & & & & $\mathrm{Y}$ & & $\mathrm{Y}$ & & & & $\mathrm{Y}$ & & & $\mathrm{Y}$ & $\mathrm{Y}$ \\
\hline All discrete, size-resolved aerosol particles & & & & & & & & $\mathrm{Y}$ & $\mathrm{Y}$ & & $\mathrm{Y}$ & $\mathrm{Y}$ & & \\
\hline $\begin{array}{l}\text { All chemicals within discrete, size-resolved } \\
\text { aerosol particles }\end{array}$ & & & & & & & & $\mathrm{Y}$ & $\mathrm{Y}$ & & $\mathrm{Y}$ & & & \\
\hline $\begin{array}{l}\text { All bulk or modal or size-resolved hydrometeor } \\
\text { particles }\end{array}$ & & & & & & & & & & $\mathrm{Y}$ & & $\mathrm{Y}$ & $\mathrm{Y}$ & $\mathrm{Y}$ \\
\hline $\begin{array}{l}\text { All discrete, size-resolved hydrometeor particles } \\
\text { and their aerosol inclusions }\end{array}$ & & & & & & & & & & & $\mathrm{Y}$ & & & \\
\hline \multicolumn{15}{|c|}{ Online meteorology and pollutant transport/chemistry/microphysics } \\
\hline None & & & & $\mathrm{Y}$ & & & & & & & & & & \\
\hline Time-dependent for $\mathrm{O}_{3}$ only & $\mathrm{Y}$ & $\mathrm{Y}$ & $\mathrm{Y}$ & & & & $\mathrm{Y}$ & & & & & & & \\
\hline $\begin{array}{l}\text { Time-dependent for } \mathrm{O}_{3} \text { and some gases; steady- } \\
\text { state or family chemistry for others gases }\end{array}$ & & & & & Y & Y & & & & & & & & \\
\hline $\begin{array}{l}\text { Time-dependent for all reacting and transported } \\
\text { gases }\end{array}$ & & & & & & & & $\mathrm{Y}$ & $\mathrm{Y}$ & $\mathrm{Y}$ & $\mathrm{Y}$ & $\mathrm{Y}$ & $\mathrm{Y}$ & Y \\
\hline $\begin{array}{l}\text { Time-dependent for aerosols with comprehensive } \\
\text { dynamics treatments }\end{array}$ & & & & & & & & $\mathrm{Y}$ & $\mathrm{Y}$ & Y & $\mathrm{Y}$ & $\mathrm{Y}$ & $\mathrm{Y}$ & $\mathrm{Y}$ \\
\hline \multicolumn{15}{|c|}{ Online pollutant feedbacks to heating rates to drive meteorology } \\
\hline No feedback & $\mathrm{Y}$ & & & & $\mathrm{Y}$ & & & & & & & & $\mathrm{Y}$ & \\
\hline Feedback of online $\mathrm{O}_{3}$ to lookup-table heating rate & & & $\mathrm{Y}$ & & & & & & & & & & & \\
\hline $\begin{array}{l}\text { Feedback of online } \mathrm{O}_{3} \text { to online parameterized } \\
\text { heating rate }\end{array}$ & & $\mathrm{Y}$ & & & & & $\mathrm{Y}$ & & & & & & & \\
\hline $\begin{array}{l}\text { Feedback of a few gases to heating rates from } \\
\text { spectral radiative transfer }\end{array}$ & & & & & & & & & & $\mathrm{Y}$ & & $\mathrm{Y}$ & & Y \\
\hline $\begin{array}{l}\text { Feedback of all photochemically-active gases to } \\
\text { heating rates from spectral radiative transfer }\end{array}$ & & & & & & & & $\mathrm{Y}$ & $\mathrm{Y}$ & & $\mathrm{Y}$ & & & \\
\hline $\begin{array}{l}\text { Feedback of online bulk or modal or size-resolved } \\
\text { aerosol to parameterized heating rate }\end{array}$ & & & & $\mathrm{Y}$ & & $\mathrm{Y}$ & & & & $\mathrm{Y}$ & & $\mathrm{Y}$ & & \\
\hline $\begin{array}{l}\text { Feedback of all discrete size-resolved aerosols to } \\
\text { heating rates from spectral solar and thermal-IR } \\
\text { radiative transfer }\end{array}$ & & & & & & & & $\mathrm{Y}$ & $\mathrm{Y}$ & & $\mathrm{Y}$ & & & \\
\hline $\begin{array}{l}\text { Feedback of all discrete size-resolved hydrom- } \\
\text { eteors to heating rates from spectral solar and } \\
\text { thermal-IR radiative transfer }\end{array}$ & & & & & & & & & $\mathrm{Y}$ & & $\mathrm{Y}$ & & & \\
\hline \multicolumn{15}{|c|}{ Online pollutant feedbacks to photolysis to drive photochemistry } \\
\hline No photolysis & & & & $\mathrm{Y}$ & & & & & & & & & & \\
\hline $\begin{array}{l}\text { Photolysis from lookup table or fixed or a prepro- } \\
\text { cessor model, without feedback }\end{array}$ & $\mathrm{Y}$ & $\mathrm{Y}$ & & & $\mathrm{Y}$ & $\mathrm{Y}$ & & & & & & & $\mathrm{Y}$ & \\
\hline $\begin{array}{l}\text { Feedback of online } \mathrm{O}_{3} \text { only to lookup-table pho- } \\
\text { tolysis }\end{array}$ & & & $\mathrm{Y}$ & & & & $\mathrm{Y}$ & & & & & & & \\
\hline $\begin{array}{l}\text { Feedback of a few gases to online photolysis from } \\
\text { spectral radiative transfer }\end{array}$ & & & & & & & & & & $\mathrm{Y}$ & & Y & & Y \\
\hline $\begin{array}{l}\text { Feedback of all gases to online photolysis from } \\
\text { spectral radiative transfer }\end{array}$ & & & & & & & & $\mathrm{Y}$ & $\mathrm{Y}$ & & $\mathrm{Y}$ & & & \\
\hline $\begin{array}{l}\text { Feedback of online bulk or modal or size-resolved } \\
\text { aerosol to parameterized photolysis schemes }\end{array}$ & & & & & & & & & & $\mathrm{Y}$ & & $\mathrm{Y}$ & & \\
\hline $\begin{array}{l}\text { Feedback of all discrete size-resolved aerosols to } \\
\text { photolysis from spectral radiative transfer }\end{array}$ & & & & & & & & $\mathrm{Y}$ & $\mathrm{Y}$ & & $\mathrm{Y}$ & & & \\
\hline $\begin{array}{l}\text { Feedback of all discrete size-resolved hydromete- } \\
\text { ors to photolysis from spectral radiative transfer }\end{array}$ & & & & & & & & & $\mathrm{Y}$ & & $\mathrm{Y}$ & & & \\
\hline
\end{tabular}

A75 - Atwater, M. A. (1975), B88 - Baklanov (1988), C70 - Clark J.H.E. (1970), C75 - Cunnold et al. (1975), C85 - Cess et al. (1985), F06 - Fast et al. (2006), G91 - Granier and Brasseur (1991), G05 - Grell et al. (2005), H69 - Hunt (1969), J94 - Jacobson (1994), J95 Jacobson (1995), J96 - Jacobson et al. (1996), J97a - Jacobson (1997a), J97b - Jacobson (1997b), J02 - Jacobson (2002), J04a - Jacobson et al. (2004), J04b - Jacobson and Seinfeld (2004), J04c - Jacobson (2004a), J04d - Jacobson (2004b), J06 - Jacobson and Kaufmann (2006), J07 - Jacobson et al. (2007), Jo76 - Joseph (1976), Jö06 - Jöckel et al. (2006), L00 - Langmann (2000), P84 - Penenko et al. (1984), P92 Pitari et al. (1992), R95 - Rasch et al. (1995), S79 - Schlesinger and Mintz (1979), and T85 - Thompson (1985). 


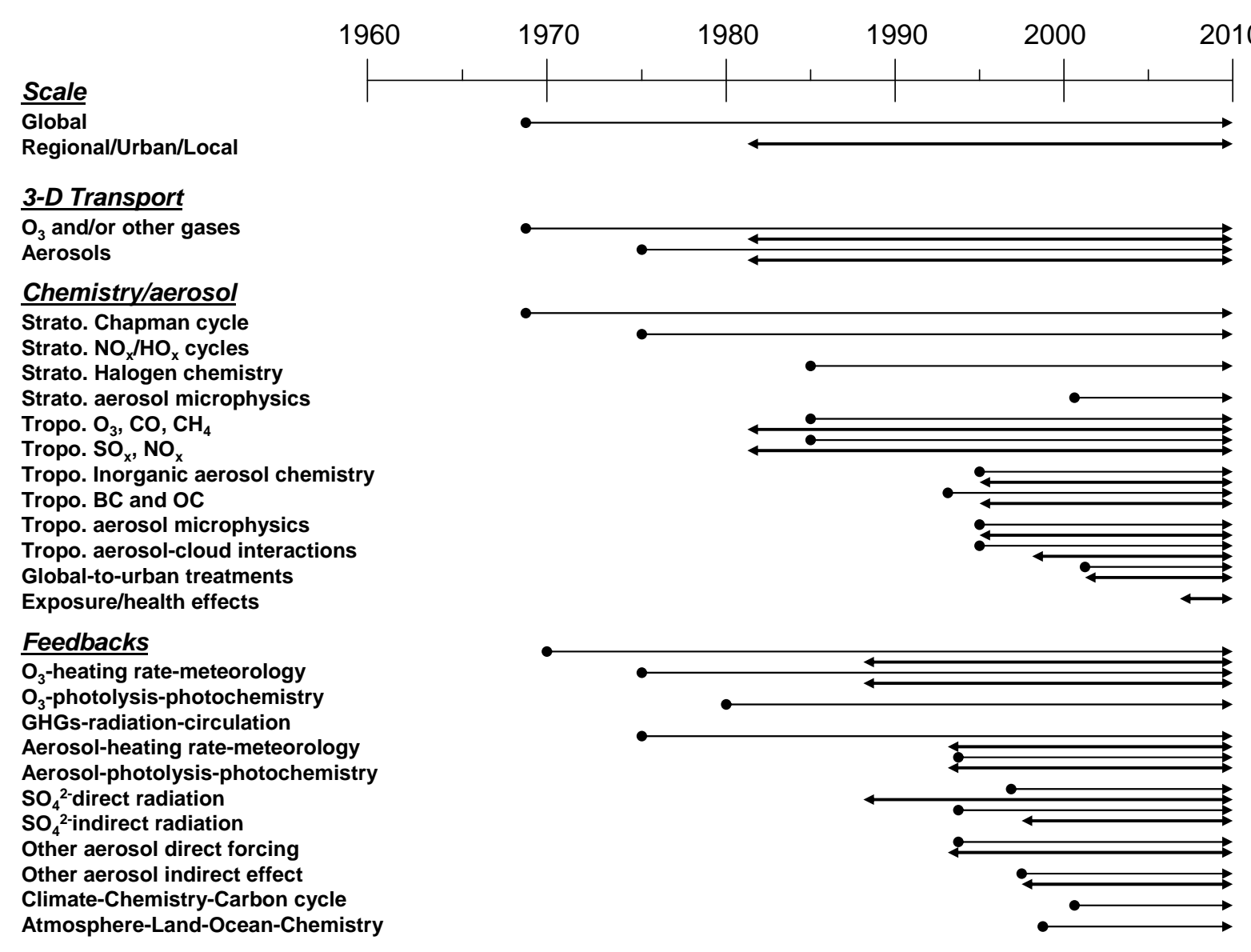

Fig. 1. The development history in chronological order and milestones in terms of chemistry/aerosol and feedback treatments for onlinecoupled models. $\longleftrightarrow$ and $\longleftrightarrow$ indicate the time and treatments in global and regional models, respectively.

of the development history and major milestones in terms of transport of gaseous and aerosols species, their chemistry, and feedbacks among major atmospheric processes for online-coupled models on all scales. The earliest attempt in coupling global climate/meteorology and chemistry can be traced back to late 1960's, when 3-D transport of $\mathrm{O}_{3}$ and very simple stratospheric chemistry (e.g., the Chapman reactions) were first incorporated into a GCM to simulate global $\mathrm{O}_{3}$ production and transport simultaneously (e.g., Hunt, 1969; Clark, 1970). Coupled climate-chemistry GCMs developed in mid-late 1970's included additional reactions (e.g., the nitrogen oxides $\left(\mathrm{NO}_{\mathrm{x}}\right)$ catalytic cycle, and reactions between hydrogen and atomic oxygen) and accounted for the effects of predicted $\mathrm{O}_{3}$ (but not other gases) on radiation heating and the effect of $\mathrm{O}_{3}$ 's heating on atmospheric circulation, which in turn affected the distributions of $\mathrm{O}_{3}$ (e.g., Cunnold et al., 1975; Schlesinger and Mintz, 1979). 3-D transport of bulk aerosols and their feedbacks into radiation heating to drive meteorology were also included in some early coupled GCMs (e.g., Atwater, 1975; Joseph, 1976; Covey et al., 1984; Thompson, 1985; Cess e al., 1985; Malone et al., 1986; Ghan et al., 1988). The earliest attempt in coupling meteorology and air pollution in local to regional scale models can be traced back to early 1980s. The one-way coupling of 3-D transport of gases and gas-phase chemistry with meteorology was included at meso-to-regional scales (e.g., Marchuk, 1982; Penenko et al., 1984; Penenko and Aloyan, 1985; and Bazhin et al., 1991) and local-to-meso scale (e.g., Aloyan et al., 1982; Baklanov, 1988). In addition to the one-way coupling of transport and gas-phase chemistry, Baklanov (1988) also included highly-simplified aerosol treatments and the direct radiation feedbacks of bulk aerosols to heating/reflection and other atmospheric processes at a local scale.

Since the mid. 1980's, a larger number of online-coupled global climate-chemistry models with various degrees of coupling to chemistry have been developed to address the Antarctic/stratospheric $\mathrm{O}_{3}$ depletion (e.g., Cariolle et al., 1986, 1990; Rose and Brasseur, 1989; Granier and Brasseur, 1991; Austin and Butchart, 1992; Austin et al., 1992, 2000; 
Pitari et al., 1992, 2002; Hack et al., 1993; Rasch et al., 1995; Jacobson, 1995; Eckman et al., 1996; Beagley et al., 1997; Shindell et al., 1998; Dameris et al., 1998, 2005; Takigawa et al., 1999; Rozanov et al., 2001; Nagashima et al., 2002; and Schnadt et al., 2002), tropospheric $\mathrm{O}_{3}$ and sulfur cycle (e.g., Levy et al., 1985; Roelofs and Lelieveld, 1995; Roelofs et al., 1998; Feichter et al., 1996, 1997; de Laat et al., 1999; Mickley et al., 1999; Rasch et al., 2000; Barth et al., 2000; Shindell et al., 2001; Grenfell et al., 2001; Wong et al., 2004; and Jöckel et al., 2006), both tropospheric and stratospheric chemistry (Jöckel et al., 2006 and Teyssèdre et al., 2007), and tropospheric aerosols, their direct radiative forcing and interactions with clouds (e.g., Taylor and Penner, 1994; Chuang et al., 1997, 2002; Lohmann and Feichter, 1997; Koch et al., 1999; Kiehl et al., 2000; Lohmann et al., 2000; Jacobson, 2000, 2001a, 2002; Ghan et al., 2001a, b, c; Boucher and Pham, 2002; Menon et al., 2002; Gong et al., 2002, 2003; Iversen and Seland, 2002; Derwent et al., 2003; Liao et al., 2003; Easter et al., 2004; Hauglustaine et al., 2004; Stier et al., 2005, 2007; and Lohmann et al., 2007). Such onlinecoupled models have also been expanded to study climatecarbon cycle-chemistry feedbacks in the middle atmosphere (e.g., Steil et al., 2003 and Manzini et al., 2003), and the interactions among atmosphere, biosphere, ocean, and land systems (referred to as earth system modeling) since late 1990's (e.g., Prinn et al., 1999; Gordan et al., 2000; Neelin and Zeng, 2000; Cox, 2001; Johnson et al., 2001; Khodri et al., 2001; Jacobson, 2004b, 2005b, 2006a; Jöckel et al., 2005; Collins et al., 2006b; Chou et al., 2006; Doney et al., 2006; Jungclaus et al., 2006; and O'Connor et al., 2006). The online-coupled meteorology-chemistry models developed at urban/regional scales for studies of tropospheric air pollutants and their interactions with regional climate and meteorology include those in North America (e.g., Jacobson, 1994, 1997a, b; Mathur et al., 1998; Xiu et al., 1998; Côté et al., 1998; Grell et al., 2000, 2005; Fast et al., 2006; and Kaminski, 2007), Asia (e.g., Uno et al., 2001; 2003), Australia (e.g., Manins, 2007), and Europe (e.g., Tulet et al., 1999, 2003, 2005, 2006; Langmann, 2000, 2007; Langmann et al., 2008; Wolke et al., 2003; Chenevez et al., 2004; Baklanov et al., 2004, 2007a, b, and references therein; Vogel et al., 2006; Vogel, 2007; Maurizi, 2007; and Korsholm et al., 2007). Some of European online models were developed through the European Cooperation in Science and Technology (COST) action 728 (http://www.cost728.org). Among these mesoscale models, the work done by Jacobson (1994, $1997 \mathrm{a}, \mathrm{b})$ is the one with the highest degree in coupling. In his model, chemistry is solved for all transported gases; all chemically-active gases and size-resolved aerosol components are transported; and feedbacks of all photolyzing gases and aerosols to meteorology through heating rates and to photolysis through actinic fluxes are treated (see Table 1). Some of the mesoscale online meteorology-chemistry models have been coupled with population exposure and health effects (e.g., Jacobson, 2007 and Baklanov et al., 2007b).
Several online-coupled regional climate-chemistry/aerosol models have also been developed since late 1999, with either a sulfate-like tracer (e.g., Qian and Giorgi, 1999) or highly-simplified sulfate chemistry (e.g., Qian et al., 2001 and Giorgi et al., 2002) simulated in a regional climate model. The coupling was enabled partially, i.e., only between meteorology and tropospheric gas-phase chemistry in some regional online models (e.g., Grell et al., 2000; Taghavi et al., 2004 and Arteta et al., 2006); and significantly to fully, i.e., among more processes/components including meteorology, chemistry, aerosols, clouds, and radiation (e.g., Jacobson, 1994, 1997a, b; Jacobson et al., 1996; Mathur et al., 1998; Grell et al., 2005; Fast et al., 2004, 2006; Zhang et al., 2005a, b; Hu and Zhang, 2006; Gustafson et al., 2007; Korsholm et al., 2007; Sofiev, 2007; and Knoth and Wolke, 2007). Some online-coupled GCMs for stratospheric chemistry have been reviewed in Austin et al. (2003) and Eyring et al. (2005); those for tropospheric chemistry have been reviewed in Ghan et al. (2001c), Easter et al. (2004), Textor et al. (2006), and Ghan and Schwartz (2007), and those for earth system modeling have been reviewed in Friedlingstein et al. (2006). Some of the mesoscale online-coupled models have been briefly reviewed in Baklanov $(1990,2007)$ and Baklanov et al. (2007a).

The coupling in most global online-coupled climatechemistry models, however, is largely incomplete; and has been done only for very limited prognostic gaseous species such as $\mathrm{O}_{3}$ and/or bulk sulfate aerosol or selected processes such as transport and gas-phase chemistry (i.e., slightlyor moderately-coupling, e.g., Hunt, 1969; Atwater, 1975; Schlesinger and Mintz, 1979; Taylor and Penner, 1994). This is mainly because such a coupling typically restricts to gas-phase or parameterized chemistry (and heterogeneous chemistry in some cases) and simple aerosol/cloud chemistry and microphysics and often neglects the feedbacks between prognostic chemical species (e.g., $\mathrm{O}_{3}$ and aerosols) and radiation (e.g., Roelofs and Lelieveld, 1995; Eckman et al., 1996; Barth et al., 2000; Wong et al., 2004; Lamarque et al., 2005) and between aerosols and clouds (e.g., Liao et al., 2003; Lamarque et al., 2005). There are, however, a few exceptions after mid. 1990's when significantlyor fully-coupled systems were developed to enable a full range of feedbacks between meteorology/climate variables and a myriad of gases and size-resolved aerosols (e.g., Jacobson, 1995, 2000; Ghan et al., 2001a, b, c). Similar to global models, the feedbacks between meteorology and chemical species are often neglected in many local-toregional scale online models (e.g., Uno et al., 2001, 2003), and a full range of climate-chemistry-aerosol-cloud-radiation feedbacks is treated in very few mesoscale models (e.g., Jacobson, 1994, 1997a, b; Grell et al., 2005). 


\subsection{History of online-coupled models developed in the US}

The current status of a number of online models in Europe has been reviewed in Baklanov and Korsholm (2007) and Baklanov et al. (2007a). Most of the European online models were developed in recent years, and very few of them are fully-coupled models that account for all major feedbacks. In this work, five online models on both regional and global scales developed in the US are selected to represent the current status of online-coupled models worldwide and reviewed in details. These models include one global-throughurban model, i.e., the Gas, Aerosol, TranspOrt, Radiation, General Circulation, Mesoscale, Ocean Model (GATORGCMOM) (Jacobson, 2001b, 2002, 2004a, b; Jacobson et al., 2004), one mesoscale model, i.e., the Weather Research and Forecasting/Chemistry model (WRF/Chem) (Grell et al., 2005; Fast et al., 2006), and three global models, i.e., the Community Atmospheric Model v. 3 (CAM3) (Collin et al., 2006a), the Model for Integrated Research on Atmospheric Global Exchanges version 2 (MIRAGE2); Textor et al., 2006; Ghan and Easter, 2006), and the Caltech unified GCM (Liao et al., 2003, 2004, 2006; Liao and Seinfeld, 2005). All these models predict gases, aerosols, and clouds with varying degrees of complexities in chemical mechanisms and aerosol/cloud microphysics. While GATOR-GCMOM, WRF/Chem, and MIRAGE represent the state-of-the-science online-coupled models in the world with many feedbacks accounted for, CAM3 and Caltech unified GCM represent the current transition of 3-D models from offline to online in which meteorology and chemistry are coupled and feedbacks among various processes are being accounted for. In the following section, history and current status of the five models along with other relevant models developed in the US are reviewed.

Jacobson (1994) developed a unified fully-coupled online meteorology-chemistry-aerosol-radiation model on urban and regional scale: a gas, aerosol, transport, and radiation air quality model/a mesoscale meteorological and tracer dispersion model (GATOR/MMTD, also called GATORM) (Jacobson, 1994; 1997a, b; Jacobson et al., 1996). This is the first fully-coupled online model in the history that accounts for all major feedbacks among major atmospheric processes based on first principles (Jacobson, 2006a), since early work on the coupling of meteorology and chemistry were done in an either slightly- or somewhat incompletelycoupled fashion and the feedbacks among multiple processes in those online models were either omitted or largely simulated with simplified parameterizations. In an early version of GATOR/MMTD, all meteorological and chemical processes were solved simultaneously online but with separate transport schemes for meteorological and chemical variables. The two-way feedbacks between gases/aerosols and meteorology through solar and thermal-IR radiative transfer were accounted for. The same transport scheme was developed for GATOR/MMTD in 1997 to solve transport of water va- por, energy, and column pressure in MMTD and of chemical species in GATOR (Jacobson, 1997c). GATOR/MMTD has been applied to simulate gases and aerosols over Los Angeles (LA) Basin (Jacobson et al., 1996; Jacobson, 1997a, b), the effects of aerosols on vertical photolysis rate and temperature profiles (Jacobson, 1998), nitrated and aromatic aerosols and nitrated aromatic gases as sources of ultraviolet light absorption (Jacobson, 1999a), the effects of soil moisture on temperatures, winds, and pollutant concentrations in LA (Jacobson, 1999b), and the effects of different vehicle fuels on cancer and mortality (Jacobson, 2007). The results from those model applications have been rigorously evaluated with available measurements.

Grell et al. (2000) developed a unified coupled online meteorology and chemistry model: Multiscale Climate Chemistry Model (MCCM, also called Mesoscale Model (MM5)/Chem). In this model, the Penn State University (PSU)/the National Center for Atmospheric Research (NCAR) nonhydrostatic mesoscale model (MM5, Grell et al., 1994) was coupled online only with the gas-phase chemical mechanism of the Regional Acid Deposition Model, version 2 (RADM2, Chang et al., 1989; Stockwell et al., 1990). No aerosol and radiation processes were treated in MM5/Chem. MM5/Chem was applied and evaluated with several testbeds in the US (e.g., McKeen et al., 2003; Eder et al., 2005; Bao et al., 2005; Kang et al., 2005; Kim and Stockwell, 2007). Built upon their work on MM5/Chem, Grell at al. (2002) developed a unified significantly-coupled mesoscale meteorology/chemistry/aerosol/radiation model, WRF/Chem. WRF/Chem represents the first community online-coupled model in the US. Different from other models, a community model refers to a model that is publicly available. This type of model represents synergetic model development efforts by contributors from community and also a major trend of development and application of current models including online-coupled models. Since its first public release in 2002, WRF/Chem has attracted a number of external developers and users from universities, research organizations, and private sectors to continuously and collaboratively develop, improve, apply, and evaluate the model. Although the coupling of all simulated processes in current version of WRF/Chem is not as completed as that of GATOR/MMTD and some couplings are still partially completed and/or largely based on parameterizations (e.g., Fast-J photolysis algorithm does not account for the feedbacks of all photochemically-active gases to photolysis), the degree of coupling for many atmospheric processes is much more significant as compared with earlier work. In WRF/Chem, transport of meteorological and chemical variables is treated using the same vertical and horizontal coordinates and the same transport scheme with no interpolation in space and time. The meteorological model is based on the NCAR's WRF that offers options for hydrostatic and nonhydrostatic, with several dynamic cores (e.g., the Advanced Research WRF with the Eulerian Mass (ARW) and 
the Nonhydrostatic Mesoscale Model (NMM)), and many options for physical parameterizations for applications at different scales. The chemistry model of WRF/Chem is largely based on MM5/Chem of Grell et al. (2000) but with an additional gas-phase mechanism: the Regional Atmospheric Chemistry Mechanism (RACM) of Stockwell et al. (1997) and a new aerosol module: the Modal Aerosol Dynamics Model for Europe (MADE) (Ackermann et al., 1998) with the secondary organic aerosol model (SORGAM) of Schell et al. (2001) (referred to as MADE/SORGAM). The photolytic rates of photochemical reactions are calculated online using the Tropospheric Ultraviolet and Visible radiation model (TUV) algorithm of Madronich (1987), in which the radiative transfer model of Chang et al. (1989) is used to calculate actinic flux due to absorption by two gases (i.e., $\mathrm{O}_{2}$ and $\mathrm{O}_{3}$ ), Rayleigh scattering, and scattering and absorption by aerosols and clouds. The feedbacks of gases and aerosols to radiation heating are simulated using atmospheric longwave radiation schemes (e.g., the RRTM of Mlawer et al., 1997) and the shortwave radiation schemes (e.g., the MM5 scheme of Dudia, 1989 and the Goddard scheme of Chou and Suarez, 1994) (Skamarock et al., 2005). RRTM is a spectralband scheme based on the correlated- $k$ method and uses precalculated tables to simulate feedbacks to longwave due to water vapor $\left(\mathrm{H}_{2} \mathrm{O}\right), \mathrm{O}_{3}$, carbon dioxide $\left(\mathrm{CO}_{2}\right)$, other trace gases such as nitrous oxide $\left(\mathrm{N}_{2} \mathrm{O}\right)$, methane $\left(\mathrm{CH}_{4}\right)$, trichlorofluoromethane (CFC-11), dichlorofluoromethane (CFC12), chlorofluorocarbon 22 (CFC-22), and carbon tetrachloride $\left(\mathrm{CCl}_{4}\right)$, and clouds. The MM5 shortwave scheme simulates a simple downward integration of solar flux. It accounts for clear-air scattering and absorption of $\mathrm{H}_{2} \mathrm{O}$ only (instead of all photolyzing gases) using parameterizations and cloud albedo and absorption using look-up tables. The Goddard shortwave scheme is used in a two-stream approach that accounts for scattered and reflected components over 11 spectral bands.

Two additional gas-phase mechanisms, two new aerosol modules, and one photolytic algorithm have recently been incorporated into the latest version of WRF/Chem (version 2.2) by external developers (Fast et al., 2004, 2006; Zhang et al., 2005a, 2007; Hu and Zhang, 2006, 2007; Huang et al., 2006; Pan et al., 2008). The two new gas-phase mechanisms are the Carbon-Bond Mechanism version Z (CBM-Z) (Zaveri and Peters, 1999) and the 2005 version of Carbon Bond mechanism (CB05) of Yarwood et al. (2005) and Sarwar et al. $(2005,2008)$ (both are variants of Carbon Bond Mechanism IV (CBM-IV) of Gery et al., 1989). The two new aerosol modules are the Model for Simulating Aerosol Interactions and Chemistry (MOSAIC) (Zaveri et al., 2008) and the Model of Aerosol Dynamics, Reaction, Ionization, and Dissolution (MADRID) (Zhang et al., 2004). An alternative photolysis algorithm, the Fast-J scheme of Wild et al. (2000), has been incorporated into WRF/Chem by Fast et al. (2006). Fast-J scheme computes photolysis rates from the predicted $\mathrm{O}_{3}$, aerosol, and clouds following a Legendre expansion of the exact scattering phase function, it however does not account for the feedbacks of other radiatively absorbing gases such as $\mathrm{NO}_{2}$, formaldehyde ( $\mathrm{HCHO}$ ), peroxyacetyl nitrate (PAN), hydroperoxy radical $\left(\mathrm{HO}_{2}\right)$, and nitric acid $\left(\mathrm{HNO}_{3}\right)$ to the online calculation of photolysis. CBM-Z can use the photolysis rates from either Fast-J or TUV. The aerosol optical depth, single scattering albedo, and phase function expansion coefficients are calculated as a function of the refractive indices and size distribution based on predicted aerosol mass and composition.

On a global scale, a number of climate or air quality models have been developed in the US in the past three decades among which very few of them are online-coupled models (e.g., the NCAR Community Climate Model (CCM) (which was renamed later as Community Atmospheric Model (CAM)); the Pacific Northwest National laboratory (PNNL)'s MIRAGE; the Stanford University's GATORG (which was later extended as a global-through-urban model, GATOR-GCMOM), and the Caltech unified GCM). Since its initial development as a GCM without chemistry, CCM0 and CCM1 (Washington, 1982; Williamson et al., 1987), the NCAR CCM has evolved to be one of the first-generation unified online climate-chemistry models in the US following pioneer work by Hunt (1969) and Clark (1970), initially with gas-phase chemistry only (e.g., CCM2 (Hack et al., 1993; Rasch et al., 1995) and CCM3; Kiehl et al., 1998; Rasch et al., 2000; Barth et al., 2000) and most recently with additional aerosol treatments (e.g., CAM3 (Collins et al., 2004, 2006a, b; Rasch et al., 2006a, b) and CAM4 (http://www.ccsm.ucar.edu) and online calculations of soil dust and seat salt emissions (Mahowald et al., 2006a, b).

Jacobson (1995, 2000, 2001a) developed a unified fullycoupled Gas, Aerosol, TranspOrt, Radiation, and General circulation model (GATORG). Similar to GATOR-MMTD on urban/regional scales, this is the first fully-coupled global online model in the history that accounts for all major feedbacks among major atmospheric processes based on first principles. While the gas-aerosol-radiation modules in GATORG are the same as those in GATORM, GATORG uses a 1994 version of the University of Los Angeles General Circulation Model (UCLA-GCM) (Arakawa and Lamb, 1981) to generate meteorology. GATORG was used to study global direct aerosol radiative forcing (Jacobson, 2000, 2001a). Jacobson $(2001 b, c)$ linked the regional GATORM and global GATORG and developed the first in the history unified, nested global-through-urban scale Gas, Aerosol, Transport, Radiation, General Circulation, and Mesoscale Meteorological model, GATOR-GCMM. GATOR-GCMM is designed to treat gases, size- and composition-resolved aerosols, radiation, and meteorology for applications from the global to urban $(<5 \mathrm{~km})$ scales and includes switches to run in global mode, regional mode, nested mode, and with/without gases, aerosols and cloud microphysics, radiation, meteorology, transport, deposition and sedimentation, and surface processes. All processes in all nested domains are 
exactly the same, except for the horizontal boundary conditions and solutions to the momentum equation that are different on global and regional scales. GATOR-GCMM accounts for radiative feedbacks from gases, size-resolved aerosols, liquid water and ice particles to meteorology on all scales and has been applied to study weather and tropospheric $\mathrm{O}_{3}$ in northern and central California and global direct forcing of BC (Jacobson, 2001c, d, 2002). GATORGCMM was extended to Gas, Aerosol, TranspOrt, Radiation, General Circulation, Mesoscale, Ocean Model (GATORGCMOM) in Jacobson (2004a, b, 2005b, 2006b) and Jacobson et al. $(2004,2006 \mathrm{~b}, 2007)$ by the addition of a 2-D ocean module with 3-D energy diffusion to the deep ocean and treatments of multiple-distribution, size-resolved cloud hydrometeors and interactions between these hydrometeors and size- and distribution-resolved aerosols.

MIRAGE2 is an aerosol-climate model built upon the NCAR CAM2 climate model. Most of its treatments of aerosol chemistry and physics are from its predecessor MIRAGE1 (Ghan et al., 2001a, b, c; Easter et al., 2004) which used the same Pacific Northwest National Laboratory (PNNL) Global Chemistry Model (GChM) but a different framework (i.e., the NCAR CCM2 climate model coupled online with a chemical transport model). The NCAR CCM2 climate model and GChM in MIRAGE1 can be run offline or online via an interface (i.e., separate online coupling) (Ghan et al., 2001 a, b, c; Easter et al., 2004). In MIRAGE2, the gas/aerosol treatments are an integrated model imbedded in NCAR CAM2 (i.e., unified online coupling). As a result, the treatment of the cloud processing of gas/aerosols in MIRAGE2 is closer to that in CAM2, as compared to MIRAGE1. Also, the transport/advection treatments in MIRAGE 2 are numerically identical for water and gas/aerosol species. The prescribed $\mathrm{CH}_{4}, \mathrm{NO}_{\mathrm{x}}$, and $\mathrm{O}_{3}$ but prognostic steady state $\mathrm{OH}$ and $\mathrm{HO}_{2}$ are used in MIRAGE 1 and offline oxidant chemistry (except for prognostic $\mathrm{H}_{2} \mathrm{O}_{2}$ using offline $\mathrm{HO}_{2}$ ) is used in MIRAGE 2. Both MIRAGE 1 and 2 contain identical aerosol treatments. The aqueous chemistry and wet removal are simulated online in MIRAGE 2.

Several other online-coupled global climate/aerosol models with full oxidant chemistry have also been developed since early 2000 but most of them do not include all feedbacks, in particular, aerosol indirect effects; and they are still under development (e.g., Liao et al., 2003). Among all 3-D models that have been developed for climate and air quality studies at all scales, GATOR-GCMOM, MIRAGE, and WRF/Chem represent the state-of-the-science global and regional coupled models worldwide; and GATOR-GCMOM (Jacobson, $2001 \mathrm{a}, \mathrm{b}, \mathrm{c}, 2004 \mathrm{a}, \mathrm{b}$ ) appears to be the only model that represents gas, size- and composition-resolved aerosol, cloud, and meteorological processes from the global down to urban scales via nesting, allowing feedbacks from gases, aerosols, and clouds to meteorology and radiation on all scales in one model simulation.

\section{Current treatments in online-coupled models}

In this section, model features and treatments of major aerosol and cloud processes for the five aforementioned online-coupled meteorology and chemistry models developed in the US are reviewed and intercompared. The review is presented in terms of model systems and typical applications, aerosol and cloud properties, aerosol and cloud microphysics and aerosol-cloud interactions.

\subsection{Chemistry, emissions, and typical model applications}

As shown in Table 2, the five models consist of a meteorology model (either a GCM or a mesoscale model) and a chemical transport model with different levels of details in gas-phase chemistry and aerosol and cloud treatments ranging from the simplest one in CAM3 to the most complex one in GATOR-GCMOM. GATOR-GCMOM uses an extended Carbon Bond mechanism (CBM-EX) with 247 gasphase reactions among 115 chemical species. Its aqueous chemical mechanism simulates 64 kinetic aqueous-phase reactions for sulfate, nitrate, organics, chlorine, oxidant, and radical chemistry and offers options for bulk or sizeresolved chemistry. Its aerosol and cloud modules provide comprehensive treatments for size-resolved, prognostic aerosol/cloud properties and processes. WRF/Chem offers four options for gas-phase mechanisms (i.e., RADM2, RACM, CBM-Z, and CB05) with 156-237 chemical reactions among 52-77 chemical species and three aerosol modules (i.e., MADE/SORGAM, MOSAIC, and MADRID). CBM-Z extends the original CBM-IV mechanism to function properly at regional to global spatial scales and longer time periods than the typical urban air-shed simulations. The CBM-Z version implemented in WRF/Chem also includes a condensed dimethylsulfide (DMS) photooxidation mechanism (Zaveri, 1997) to simulate the temperature-dependent formation of $\mathrm{SO}_{2}, \mathrm{H}_{2} \mathrm{SO}_{4}$, and methanesulfonic acid (MSA) in the marine environment. Compared with CBM-IV, the main changes in CB05 include updates of kinetic data (i.e., rate coefficients) and photolysis data (i.e., absorption crosssections and quantum yields), extended inorganic reaction set (e.g., reactions involving $\mathrm{H}_{2}$ and $\mathrm{NO}_{3}$ ), explicit acetaldehyde, propionaldehyde and higher aldehydes, alkenes with internal double bonds (internal olefins) (e.g., 2-butenes), oxygenated products and intermediates (e.g., higher organic peroxides and peroxycarboxylic acids), and lumped terpene chemistry. In the latest version of WRF/Chem (v. 2.2) released in March, 2007, a generic chemical kinetic solver, the Kinetic PreProcessor (KPP), has been included to facilitate the users to incorporate any new gas-phase chemical mechanisms into WRF/Chem. While MADE/SORGAM uses a modal approach with three lognormally-distributed modes to represent aerosol size distribution, the sectional approach with a number of size sections (currently with 4 or 8 sections, but it can be changed to any number of sections) is 
Table 2. Model Systems and Typical Applications of Online Models developed in the US.

\begin{tabular}{|c|c|c|c|c|c|}
\hline $\begin{array}{l}\text { Model } \\
\text { System/Scale }\end{array}$ & $\begin{array}{l}\text { Meteorology } \\
\text { Model }\end{array}$ & $\begin{array}{l}\text { Chemical Transport Model } \\
\text { (Main features) }\end{array}$ & Emissions & $\begin{array}{l}\text { Typical } \\
\text { Applications }\end{array}$ & $\begin{array}{l}\text { Example } \\
\text { References }\end{array}$ \\
\hline $\begin{array}{l}\text { GATOR-GCMOM } \\
\text { and } \\
\text { Predecessors } \\
\text { (Global-through- } \\
\text { urban) }\end{array}$ & $\begin{array}{l}\text { MMTD } \\
\text { GCMM } \\
\text { GCMOM }\end{array}$ & $\begin{array}{l}\text { Gas-phase chemistry: CBM-EX: } \\
\text { ( } 247 \text { reactions, } 115 \text { species); } \\
\text { Bulk or size-resolved aqueous-phase sulfate, nitrate, } \\
\text { organics, chlorine, oxidant, radical chemistry ( } 64 \mathrm{ki}- \\
\text { netic reactions); size-resolved, prognostic aerosol/cloud } \\
\text { with complex processes }\end{array}$ & $\begin{array}{l}\text { Online: all } \\
\text { natural gases } \\
\text { and particles } \\
\text { Offline: } \\
\text { anthropogenic } \\
\text { and volcanic } \\
\text { emissions }\end{array}$ & $\begin{array}{l}\text { Current/future } \\
\text { met/chem/rad } \\
\text { feedbacks; } \\
\text { Direct/indirect } \\
\text { effects; } \\
\text { AQ/health effect }\end{array}$ & $\begin{array}{l}\text { Jacobson, 1994, } \\
\text { 1997a, b, 2001c, } \\
\text { 2002, 2004a, b; } \\
\text { Jacobson et al., } \\
2004,2006 a, \\
2007\end{array}$ \\
\hline $\begin{array}{l}\text { WRF/Chem } \\
\text { (Mesoscale) }\end{array}$ & WRF & $\begin{array}{l}\text { RADM2, RACM, CBM-Z, CB05 } \\
\text { (156-237 reactions, 52-77 species); } \\
\text { bulk aqueous-phase } \\
\text { RADM chemistry (MADE/SORGAM) } \\
\text { or CMU mechanism } \\
\text { (MOSAIC/MADRID; } \\
\text { Three aerosol modules } \\
\text { (MADE/SORGAM, MOSAIC, and MADRID with } \\
\text { size/mode-resolved, } \\
\text { prognostic aerosol/cloud treatments }\end{array}$ & $\begin{array}{l}\text { Online: biogenic } \\
\text { and sea-salt } \\
\text { emissions } \\
\text { Offline: } \\
\text { anthropogenic } \\
\text { emissions and } \\
\text { other natural } \\
\text { emissions }\end{array}$ & $\begin{array}{l}\text { Forecast/hindcast, } \\
\text { Met/chem feedbacks; } \\
\mathrm{O}_{3}, \mathrm{PM}_{2.5} \\
\text { Aerosol direct and in- } \\
\text { direct effects }\end{array}$ & $\begin{array}{l}\text { Grell et al. (2005); } \\
\text { Fast et al. (2006); } \\
\text { McQueen et al. } \\
\text { (2005, 2007); } \\
\text { Zhang et al. } \\
\text { (2005a, b, 2007); } \\
\text { Tie et al., 2007; } \\
\text { Gustafson et al., } \\
2007\end{array}$ \\
\hline $\begin{array}{l}\text { CAM3 and Predeces- } \\
\text { sors } \\
\text { (Global) }\end{array}$ & $\begin{array}{l}\text { CCM3/ } \\
\text { CCM2/ } \\
\text { CCM1 }\end{array}$ & $\begin{array}{l}\text { Sulfur chemistry ( } 14 \text { reactions), } \\
\text { prescribed } \mathrm{CH}_{4}, \mathrm{~N}_{2} \mathrm{O}, \mathrm{CFCs} / \mathrm{MOZART} 4 \\
\text { gas-phase chemistry ( } 167 \text { reactions, } 63 \text { species); } \\
\text { Bulk aqueous-phase sulfate chemistry of } \\
\mathrm{S}(\mathrm{IV}) \text { ( } 4 \text { equilibria and } 2 \\
\text { kinetic reactions); prognostic aerosol/cloud } \\
\text { treatments with prescribed size distribution }\end{array}$ & $\begin{array}{l}\text { Online: soil dust, } \\
\text { sea-salt, and } \\
\text { biogenic emissions } \\
\text { Offline: } \\
\text { anthropogenic } \\
\text { emissions and } \\
\text { other natural } \\
\text { emissions }\end{array}$ & $\begin{array}{l}\text { Climate; } \\
\text { Direct/indirect } \\
\text { effects; } \\
\text { Hydrological cycle }\end{array}$ & $\begin{array}{l}\text { Rasch et al., } \\
\text { 1995, 2006; } \\
\text { Kiehl et al., 1998; } \\
\text { Collins et al., } \\
\text { 2004, 2006a, b; } \\
\text { Lamarque et al., 2005; } \\
\text { Heald, } 2007\end{array}$ \\
\hline $\begin{array}{l}\text { MIRAGE2 and } 1 \\
\text { (Global) }\end{array}$ & $\begin{array}{l}\text { CAM2/ } \\
\text { CCM2 }\end{array}$ & $\begin{array}{l}\text { Gas-phase } \mathrm{CO}-\mathrm{CH}_{4} \text {-oxidant chem.(MIRAGE } 1 \text { only); } \\
\text { Bulk aqueous-phase sulfate chemistry ( } 6 \text { equilibria and } \\
3 \text { kinetic reactions); Mode-resolved simple } \\
\text { aerosol treatment; Prognostic } \\
\text { aerosol/cloud treatments }\end{array}$ & $\begin{array}{l}\text { Online: soil dust } \\
\text { and sea- salt emis- } \\
\text { sions } \\
\text { Offline: } \\
\text { anthropogenic } \\
\text { emissions and } \\
\text { other natural } \\
\text { emissions }\end{array}$ & $\begin{array}{l}\text { CO (MIRAGE } 1 \\
\text { only), Aerosol } \\
\text { mass/number, Sulfur } \\
\text { cycle; Direct/indirect } \\
\text { effects }\end{array}$ & $\begin{array}{l}\text { Ghan et al., 2001a, b, } \\
\text { Zhang et al., 2002; } \\
\text { Easter et al., 2004; } \\
\text { Textor et al., 2006; } \\
\text { Ghan and Easter, } \\
2006\end{array}$ \\
\hline $\begin{array}{l}\text { Caltech unified GCM } \\
\text { (Global) }\end{array}$ & $\begin{array}{l}\text { GISS GCM } \\
\text { II' }\end{array}$ & $\begin{array}{l}\text { Harvard tropospheric } \mathrm{O}_{3}-\mathrm{NO}_{\mathrm{x}} \text {-hydrocarbon } \\
\text { chemistry ( } 305-346 \text { reactions, } 110-225 \text { species); bulk } \\
\text { aqueous-phase chemistry of } \mathrm{S}(\mathrm{IV}) \text { ( } 5 \text { equilibria and } 3 \\
\text { kinetic reactions); } \\
\text { prognostic aerosol/cloud treatments with } \\
\text { prescribed size distribution }\end{array}$ & $\begin{array}{l}\text { Online: soil dust } \\
\text { and sea- salt } \\
\text { emissions } \\
\text { Offline: } \\
\text { anthropogenic } \\
\text { emissions and } \\
\text { other natural } \\
\text { emissions }\end{array}$ & $\begin{array}{l}\text { Global chemistry- } \\
\text { aerosol interactions; } \\
\text { aerosol direct } \\
\text { radiative forcing; } \\
\text { the role of } \\
\text { heterogeneous } \\
\text { chemistry; } \\
\text { impact of future } \\
\text { climate change on } \mathrm{O}_{3} \\
\text { and aerosols }\end{array}$ & $\begin{array}{l}\text { Liao et al., 2003, } \\
2004,2006 ; \\
\text { Liao and Seinfeld, } \\
2005\end{array}$ \\
\hline
\end{tabular}

used in MOSAIC and MADRID. RADM2 and RACM have been coupled with MADE/SORGAM and CBM-Z has been coupled with MOSAIC and MADRID; CB05 has been coupled with MOSAIC and MADRID (Zhang et al., 2007a; Pan et al., 2008). While CBM-Z and MOSAIC have been included in the latest released version 2.2 of WRF/Chem, CB05 and MADRID are being tested by the author's group and will be released in the near future. MADE/SORGAM is coupled with the bulk RADM aqueous-phase chemistry that simulates aqueous-phase chemistry of sulfate with 5 kinetic reactions, MOSAIC/MADRID is coupled with the bulk Carnegie Mellon University (CMU) aqueous-phase mechanism for chemistry of sulfate, nitrate, and oxidants that includes 147 reactions among 71 species. While all three aerosol modules provide size-resolved (in terms of either mode or section) prognostic aerosol treatments, they differ in some aspects of aerosol treatments for thermodynamics and dynamics. All three aerosol modules simulate aerosol direct radiative forcing, MOSAIC also simulates aerosol indirect forcing. CAM3 offers gas-phase chemistry with different levels of details, a simple mechanism with prescribed methane $\left(\mathrm{CH}_{4}\right)$, nitrous oxide $\left(\mathrm{N}_{2} \mathrm{O}\right)$, chlorofluorocarbons (CFCs), radicals (e.g., $\mathrm{OH}, \mathrm{HO}_{2}$ and nitrate radical $\left(\mathrm{NO}_{3}\right)$, and oxidants (e.g., $\left.\mathrm{O}_{3}\right)$ and simulated sulfur dioxide $\left(\mathrm{SO}_{2}\right) /$ dimethyl sulfide (DMS) chemistry and a more comprehensive mechanism with 167 chemical reactions among 63 species from the Model for Ozone and Related Chemical Tracers version 4 (MOZART4). It simulates bulk sulfate chemistry with dissolution equilibria of $\mathrm{SO}_{2}$, hydrogen peroxide $\left(\mathrm{H}_{2} \mathrm{O}_{2}\right), \mathrm{O}_{3}$, and sulfurous acid $\left(\mathrm{H}_{2} \mathrm{SO}_{3}\right)$ and 
aqueous-phase kinetic reactions of dissolved sulfur compounds with oxidation state IV (S(IV)) with $\mathrm{H}_{2} \mathrm{O}_{2}$ and $\mathrm{O}_{3}$. It includes prognostic aerosol/cloud treatments but with prescribed size distribution for all aerosol components except for dust and sea salt. MIRAGE2 uses offline oxidants for the carbon monoxide (CO)- $\mathrm{CH}_{4}$-oxidant chemistry (except for prognostic $\mathrm{H}_{2} \mathrm{O}_{2}$ using offline $\mathrm{HO}_{2}$ ) and treats the gasphase oxidation of $\mathrm{SO}_{2}$ and DMS by $\mathrm{OH}$. Its aqueous-phase chemistry includes dissolution equilibria of $\mathrm{SO}_{2}, \mathrm{H}_{2} \mathrm{O}_{2}, \mathrm{O}_{3}$, sulfuric acid $\left(\mathrm{H}_{2} \mathrm{SO}_{4}\right)$, and methane sulfonic acid (MSA) and aqueous-phase kinetic reactions of S(IV) with $\mathrm{H}_{2} \mathrm{O}_{2}$ and $\mathrm{O}_{3}$ in cloud water. It provides mode-resolved simple aerosol treatment with prognostic aerosol/cloud properties and processes. Caltech unified GCM uses the Harvard tropospheric $\mathrm{O}_{3}-\mathrm{NO}_{\mathrm{x}}$-hydrocarbon chemistry with 305-346 reactions among 110-225 species. Its bulk aqueous-phase chemistry simulates aqueous-phase oxidation of $\mathrm{S}(\mathrm{IV})$ by $\mathrm{H}_{2} \mathrm{O}_{2}$ and $\mathrm{O}_{3}$. Among the five models, it has the simplest aerosol treatments and no treatments for aerosol-cloud interactions.

Emissions used in these models include both natural and anthropogenic emissions. Emissions of some sources and species are a strong function of temperature (e.g., biogenic VOC emissions from vegetation, evaporative emissions for anthropogenic VOCs), solar radiation (e.g., isoprene emissions), precipitation (e.g., mercury emissions from soils), and wind speed (e.g., dust emissions from soil erosion and sea salt emissions). In order to accurately simulate the effect of climate and meteorological changes on air quality in a truly integrated manner, meteorologically-dependent emissions should be treated online. Currently, emissions are, however, treated offline in most models and very few models include online emissions for all meteorologically-dependent species. In GATOR-GCMOM, emissions of all natural gases and particles (e.g., sea spray and its chemicals, soil dust and its chemicals, lightning chemicals, pollen, spores, bacteria, biogenic gases, soil $\mathrm{NO}_{\mathrm{x}}$, and DMS from the ocean) are treated online and are affected by simulated meteorological conditions. The effect of meteorology on the height of emissions from biomass-burning and volcanos is accounted for. WRF/Chem contains online calculation of emissions of biogenic isoprene, monoterpenes, other biogenic VOCs, and nitrogen emissions by the soil based on the US EPA Biogenic Emissions Inventory System (BEIS) (www.epa.gov/ asmdnerl/biogen.html) and sea-salt (Grell et al., 2005; Fast et al., 2006). While MIRAGE 1 and MIRAGE 2 simulate seasalt emissions online, dust emissions can be simulated either online (e.g., Easter et al., 2004) or offline (e.g., Textor et al., 2006). Caltech unified GCM simulates the emissions of soil dust and sea-salt online. CAM3 simulates the emissions of soil dust and sea-salt (Tie et al., 2005; Mahowald et al., 2006 $\mathrm{a}, \mathrm{b})$ as well as biogenic species online based on the Model of Emissions of Gases and Aerosols from Nature (MEGAN) of Guenther et al. (2006) that has been incorporated into CAM3 along with the Model for Ozone and Related Chemical Tracers version 4 (MOZART-4) (Lamarque et al., 2005;
Heald, 2007) (http://www.essl.ucar.edu/LAR/2006/catalog/ $\mathrm{ACD} /$ hess.htm), although offline biogenic emissions can also be used in some CAM3 simulations.

Those models have been developed for different applications. GATOR-GCMOM has been applied for studying the effect of BC within clouds and precipitation on global climate (Jacobson, 2006b), the simulation of feedbacks among meteorology, chemistry and radiation on urban-to-global scales for both current and future emission/climate scenarios, the estimates of global aerosol direct/indirect effects (e.g., Jacobson, 2002; Jacobson et al., 2007), and the effects of ethanol versus gasoline vehicles on cancer and mortality in the US (Jacobson, 2007). WRF/Chem and its variations were developed and applied for real-time air quality forecasting (e.g., Grell et al., 2005; Kang et al., 2005; McKeen et al., 2005; 2007; Pagowski et al., 2006), although it has also been applied retrospectively for simulating concentrations and distributions of tropospheric $\mathrm{O}_{3}$ and particles with aerodynamic diameters less than or equal to $2.5 \mu \mathrm{m}\left(\mathrm{PM}_{2.5}\right)$ (e.g., Fast et al., 2004, 2006; Zhang et al., 2005a, Frost et al., 2006; Hu and Zhang, 2006; Huang et al., 2006; Hu et al., 2007; Xie et al., 2007; Gustafson et al., 2007). The feedbacks between meteorology and chemistry via aerosol radiation are studied; aerosol indirect effect through affecting cloud formation, lifetime, and precipitation is being studied with MOSAIC (Gustafson et al., 2007; Zhang et al., 2007a, 2008a). CAM3 and its predecessors were developed for global climate applications to simulate global aerosol direct/indirect effects (e.g., Kiehl et al., 2000; Collins et al., 2006a), global transport and chemistry of trace gas species (e.g., Rasch et al., 1994, 2000; Barth et al., 2000), global climate dynamic circulation (Hurrell et al., 2006) and the global hydrological cycle (Hack et al., 2006). MIRAGE2 and its predecessors were developed to simulate global climate and aerosols. It has been applied to simulate global transport and chemistry of $\mathrm{CO}$, sulfur cycle, and aerosols (e.g., Easter et al., 2004) and global cloud radiative forcing (e.g., Ghan et al., 1997a, b) and aerosol direct/indirect effects (e.g., Ghan et al., 2001a, b, c). These results have been evaluated rigorously using available gas, aerosol, and cloud measurements (Ghan et al., 2001a, b, c; Easter et al., 2004; Kinne et al., 2004, 2005). Caltech unified GCM has been applied to simulate global chemistry-aerosol interactions; aerosol direct radiative forcing; the role of heterogeneous chemistry; impact of future climate change on $\mathrm{O}_{3}$ and aerosols (Liao et al., 2003, 2004, 2006; Liao and Seinfeld, 2005).

\subsection{Aerosol properties}

As shown in Table 3, the treatments of aerosol properties in those models are different in terms of composition, size distribution, aerosol mass/number concentrations, mixing state, hygroscopicity, and radiative properties. GATORGCMOM treats 47 species including sulfate, nitrate, ammonium, BC, OC, sea-salt, dust, water $\left(\mathrm{H}_{2} \mathrm{O}\right)$, carbonate 
Table 3. Treatments of Aerosol Properties of Online Models.

\begin{tabular}{|c|c|c|c|c|c|c|}
\hline Model System & Composition & Size Distribution & $\begin{array}{l}\text { Aerosol Mixing } \\
\text { State }\end{array}$ & $\begin{array}{l}\text { Aerosol } \\
\text { Mass/Number }\end{array}$ & $\begin{array}{l}\text { Aerosol } \\
\text { Hygroscopicity }\end{array}$ & $\begin{array}{l}\text { Aerosol radiative } \\
\text { properties }\end{array}$ \\
\hline $\begin{array}{l}\text { GATOR- } \\
\text { GCMOM } \\
\text { (Global- } \\
\text { through- } \\
\text { urban) }\end{array}$ & $\begin{array}{l}47 \text { species (sulfate, nitrate, } \\
\text { ammonium, BC, OC, sea-salt, } \\
\text { dust, water, carbonate, crustal } \\
\text { species such as } \\
\mathrm{Ca}^{2+}, \mathrm{K}^{+} \text {, } \\
\text { and } \mathrm{Mg}^{2+} \text { ) }\end{array}$ & $\begin{array}{l}\text { Sectional } \\
(17-30)^{\text {a. }} \text { : } \\
\text { variable, multiple } \\
\text { size distributions }\end{array}$ & $\begin{array}{l}\text { A coated core, } \\
\text { internal/external } \\
\text { mixtures }\end{array}$ & Predicted/Predicted & $\begin{array}{l}\text { Simulated } \\
\text { hydrophobic-to- } \\
\text { hydrophilic } \\
\text { conversion for } \\
\text { all aerosol } \\
\text { components }\end{array}$ & $\begin{array}{l}\text { Simulated volume- } \\
\text { average } \\
\text { refractive indices } \\
\text { and optical } \\
\text { properties based on } \\
\text { core-shell MIE the- } \\
\text { ory }\end{array}$ \\
\hline $\begin{array}{l}\text { WRF/ } \\
\text { Chem } \\
\text { (Mesoscale) }\end{array}$ & $\begin{array}{l}\text { Sulfate, nitrate, ammonium, BC, } \\
\text { OC, and water in all three aerosol } \\
\text { modules, sea-salt and carbonate } \\
\text { in MOSAIC/MADRID, and men- } \\
\text { thansulfonate in MOSAIC }\end{array}$ & $\begin{array}{l}\text { Modal (3): variable } \\
\text { (MADE/SORGAM) } \\
\text { Sectional (8): } \\
\text { variable } \\
\text { (MOSAIC/MADRID) } \\
\text { single size } \\
\text { distribution }\end{array}$ & Internal & $\begin{array}{l}\text { Predicted/ } \\
\text { Predicted }\end{array}$ & $\begin{array}{l}\text { Similar to } \\
\text { MIRAGE2 }\end{array}$ & $\begin{array}{l}\text { Similar to } \\
\text { MIRAGE2 }\end{array}$ \\
\hline CAM3 (Global) & $\begin{array}{l}\text { Sulfate, nitrate, ammonium, BC, } \\
\text { OC, sea-salt, dust, water }\end{array}$ & $\begin{array}{l}\text { Modal (4): pre- } \\
\text { dicted dust and } \\
\text { sea-salt, prescribed } \\
\text { other aerosols; } \\
\text { single size distribu- } \\
\text { tion }\end{array}$ & External & $\begin{array}{l}\text { Prescribed or pre- } \\
\text { dicted/Diagnosed } \\
\text { from mass }\end{array}$ & $\begin{array}{l}\text { hydrophobic and } \\
\text { hydrophilic } \\
\text { BC/OC } \\
\text { with a fixed } \\
\text { conversion rate }\end{array}$ & $\begin{array}{l}\text { Prescribed RI and } \\
\text { optical properties } \\
\text { for each aero. type, } \\
\text { size, and wave- } \\
\text { length, for external } \\
\text { mixtures }\end{array}$ \\
\hline $\begin{array}{l}\text { MIRAGE2 } \\
\text { (Global) }\end{array}$ & $\begin{array}{l}\text { Sulfate, BC, OC, sea-salt, dust, } \\
\text { water }\end{array}$ & $\begin{array}{l}\text { Modal (4): } \\
\text { variable; single } \\
\text { size distribution }\end{array}$ & $\begin{array}{l}\text { Externally mixed } \\
\text { modes with } \\
\text { internal mixtures } \\
\text { within each mode }\end{array}$ & $\begin{array}{l}\text { Predicted/Diagnosed } \\
\text { or predicted }\end{array}$ & $\begin{array}{l}\text { Simulated (volume } \\
\text { averaged) } \\
\text { with prescribed } \\
\text { hygroscopities for } \\
\text { OC and dust }\end{array}$ & $\begin{array}{l}\text { Parameterized } \\
\text { RI and optical } \\
\text { properties based } \\
\text { on wet radius and } \\
\text { RI of each mode }\end{array}$ \\
\hline $\begin{array}{l}\text { Caltech unified } \\
\text { GCM (Global) }\end{array}$ & $\begin{array}{l}\text { Sulfate, nitrate, } \\
\text { ammonium, } \mathrm{BC}, \mathrm{OC}, \\
\text { sea-salt, } \\
\text { dust, water, } \\
\mathrm{Ca}^{2+}\end{array}$ & $\begin{array}{l}\text { Sectional (11) } \\
\text { prescribed for } \\
\text { sea-salt; } \\
\text { Sectional (6) } \\
\text { prescribed for } \\
\text { mineral dust; } \\
\text { Modal (1): } \\
\text { prescribed size } \\
\text { distribution for } \\
\text { other aerosols; } \\
\text { single } \\
\text { size distribution } \\
\text { for all aerosols }\end{array}$ & $\begin{array}{l}\mathrm{BC}, \mathrm{OC} \text {, and } \\
\text { mineral dust } \\
\text { externally } \\
\text { mixed with } \\
\text { internally-mixed } \\
\mathrm{SO}_{4}^{2-}, \mathrm{NH}_{4}^{+} \text {, } \\
\mathrm{NO}_{3}^{-}, \text {sea-salt, } \\
\text { and } \mathrm{H}_{2} \mathrm{O} \text {; } \\
\text { different aerosol } \\
\text { mixing states } \\
\text { for chemistry and } \\
\text { radiative forcing } \\
\text { calculation }\end{array}$ & $\begin{array}{l}\text { Predicted aerosol } \\
\text { mass; aerosol } \\
\text { number not } \\
\text { included }\end{array}$ & $\begin{array}{l}\text { Simulated BC/OC } \\
\text { with prescribed } \\
\text { hygroscopicities }\end{array}$ & $\begin{array}{l}\text { Simulated optical } \\
\text { properties based } \\
\text { on Mie theory } \\
\text { with size- and } \\
\text { wavelength- } \\
\text { dependent } \\
\text { refractive indices }\end{array}$ \\
\hline
\end{tabular}

a The number in the parentheses indicates the total of aerosol size sections or modes used in typical applications of the models.

$\left(\mathrm{CO}_{3}^{2-}\right)$, and crustal species (e.g., calcium $\left(\mathrm{Ca}^{2+}\right)$, potassium $\left(\mathrm{K}^{+}\right)$, and magnesium $\left.\left(\mathrm{Mg}^{2+}\right)\right)$ and their salts. MIRAGE2 treats the least number of species including sulfate, $\mathrm{BC}$, organic carbon (OC), sea-salt, dust, and water $\left(\mathrm{H}_{2} \mathrm{O}\right)$. Nitrate and ammonium are treated in CAM3, WRF/Chem, and Caltech unified GCM. Additional species such as calcium $\left(\mathrm{Ca}^{2+}\right)$ and carbonate $\left(\mathrm{CO}_{3}^{2-}\right)$ are treated in WRF/Chem-MOSAIC/MADRID. Both CAM3 and MIRAGE2 use modal approaches with four modes to represent aerosol size distributions. GATOR-GCMOM uses a sectional approach with 17-30 size sections for typical applications. WRF/Chem offers both approaches depending on the aerosol module selected (e.g., modal approach with 3 modes for MADE/SORGAM and sectional approach with 8 sections for MOSAIC and MADRID for typical applications). MOSAIC and MADRID can be applied for any number of size sections. Caltech unified GCM prescribes size distribution of sea-salt and dust with the sectional distribution but that of other aerosols with the modal distribution. Size distribution of all aerosol components are prescribed in Caltech unified GCM and that of all aerosols except sea-salt and dust is prescribed in CAM3; they are predicted in the other three models. Prescribed aerosol size distribution may introduce errors in simulated aerosol direct and indirect radiative forcing that highly depends on aerosol size distributions.

The mixing state of aerosols affects significantly the predictions of direct/indirect radiative forcing. For example, the direct forcing of $\mathrm{BC}$ is 0.27 for externally-mixed (i.e., distinct from other aerosol particles), 0.78 for wellmixed (i.e., incorporated within other aerosol particles), and $0.54 \mathrm{~W} \mathrm{~m}^{-2}$ for core treatments (i.e., a black-carbon core could be surrounded by a well mixed shell), according 
to Jacobson (2000). The core treatment results in values of absorption/scattering coefficients and single scattering albedo that are lower than those with well-mixed treatment but higher than those with the externally-mixed assumption. Most models assume aerosols to be either completely externally- or internally-mixed. The internally-mixed hydrophilic treatment for BC is unphysical and reality lies between the externally-mixed, hydrophobic, and core treatments. Available measurements indicate that $\mathrm{BC}$ particles are coated with a shell containing other soluble species such as sulfate, nitrate, and ammonium (e.g., Katrlnak et al., 1992, 1993; Pósfai et al., 1999). Among the five models, GATOR-GCMOM is the only model treating the transition of externally-mixed aerosols into internally-mixed aerosols with a coated $\mathrm{BC}$ core. It treats one or more size distributions of aerosols. The multiple aerosol size distributions represent aerosols with different sources and mixing states (e.g., freshly-emitted BC, internally-mixed aerosols, and aerosols with a coated BC core). The other four models treat a single aerosol distribution in either external or internal mixtures (e.g., external mixture in CAM3, internal mixture in WRF/Chem, externally-mixed aerosol modes with internal mixtures of aerosol components within each mode in MIRAGE2, and BC, OC, and mineral dust externally-mixed with internally-mixed other aerosols in Caltech unified GCM).

All five models predict aerosol mass concentration. CAM3 can also use offline aerosol mass concentrations. Aerosol number concentration is diagnosed (e.g., CAM3) or predicted (e.g., GATOR-GCMOM, WRF/Chem) or both (e.g., MIRAGE 2), but it is not included in the Caltech unified GCM. It is noted that a fixed standard deviation is used for both Aitken and accumulation modes in MADE/SORGAM in WRF/Chem, which introduces errors in simulated aerosol number and mass size distributions (Zhang et al., 1999). The simulated aerosol direct and indirect forcing depend on particle size and hygroscopicity, which should be included in atmospheric models for an accurate prediction. GATOR simulates hydrophobic-to-hydrophilic conversion for all aerosol components, MIRAGE2, WRF/Chem, and Caltech unified GCM simulate this conversion but with prescribed hygroscopicities. For example, MIRAGE assumes a hydroscopicity of 0.14 for OC, which is one-fourth of the value for ammonium sulfate $(0.51)$. For $\mathrm{BC}$, a very small nonzero value $\left(10^{-10}\right)$ is assumed to avoid computational difficulties (Ghan et al., 2001a). In Caltech unified GCM, this conversion is simulated by assuming an exponential decay lifetime of 1.15 days (Liao et al., 2003). CAM3 treats hydrophobic and hydrophilic $\mathrm{BC} / \mathrm{OC}$ but with a fixed conversion rate. It also prescribes the hygroscopicity of individual aerosol components. One difference between MIRAGE and CAM3 is that MIRAGE treats $\mathrm{BC}$ and OC from boreal fires, but CAM3 does not.
For aerosol radiative properties, refractive indices (RIs) vary as a function of particle size and composition for both aerosols and cloud droplets (as well as precipitation). GATOR-GCMOM assumes a BC core surrounded by a shell where the RIs of the dissolved aerosol components are determined from partial molar refraction theory and those of the remaining aerosol components are calculated to be volume-averaged based on core-shell Mie theory. MIRAGE2, WRF/Chem, and Caltech unified GCM predict RIs and optical properties using Mie parameterizations that are function of wet surface mode radius and RIs of wet aerosol in each mode. Volume mixing is assumed for all components, including insoluble components. The main difference between Caltech unified GCM and both MIRAGE2 and WRF/Chem is that Caltech unified GCM prescribes size distribution (e.g., a sectional distribution for seasalt and dust and a standard gamma distribution for other aerosols), but MIRAGE2 predicts it. Caltech unified GCM assumes that dust is externally-mixed with internal mixtures of other aerosols (which is different from the aerosol mixing state assumption used in the aerosol thermodynamics simulation). In CAM3, RIs and optical properties are prescribed for each aerosol type, size, and wavelength of the external mixtures.

\subsection{Model treatments of cloud properties}

Table 4 summarizes model treatments of cloud properties, reflecting the levels of details in cloud microphysics treatments from the simplest in Caltech unified GCM to the most sophisticated in GATOR-GCMOM. Hydrometeor types in clouds in GATOR-GCMOM include size-resolved liquid, ice, graupel, and aerosol core components. Liquid drops are assumed to be spherical. Ice crystals and graupel are assumed to be non-spherical. Their non-sphericity is modeled as a collection of spheres of the same total volume-to-area ratio and total volume as the nonspherical particles. GATORGCMOM uses prognostic, multiple size distributions (typically three, for liquid, ice, and graupel), each with 30 size sections. MIRAGE2 simulates prognostically a bulk cloud condensate that includes cloud water and cloud ice with water/ice fractions determined diagnostically, and precipitation is treated diagnostically. WRF/Chem includes several bulk microphysical schemes such as the Kessler scheme (Kessler 1969), the Purdue Lin scheme (Lin et al., 1983; Chen and Sun, 2002), and WRF Single-Moment (WSM) 6-class graupel scheme (Hong et al., 2006). The Purdue Lin scheme used with MOSAIC has 6 prognostic variables: water vapor, 2 bulk cloud categories (cloud water and ice), and 3 bulk precipitation categories (rain, graupel, snow/aggregates). The cloud droplet number was added by PNNL as a prognostic variable in the expanded Lin scheme that is used with MOSAIC in WRF/Chem. Both MIRAGE2 and WRF/Chem predict cloud size distribution as a single, modal distribution (Barrie et al., 2001). CAM3 treats bulk liquid and ice with 
Table 4. Treatments of Cloud Properties of Online Models.

\begin{tabular}{|c|c|c|c|c|c|c|}
\hline $\begin{array}{l}\text { Model } \\
\text { System }\end{array}$ & $\begin{array}{l}\text { Hydrometeor } \\
\text { types in } \\
\text { clouds }\end{array}$ & $\begin{array}{l}\text { Cloud droplet } \\
\text { size distribution }\end{array}$ & $\begin{array}{l}\text { Cloud droplet } \\
\text { number }\end{array}$ & $\begin{array}{l}\text { CCN/IDN } \\
\text { composition }\end{array}$ & $\begin{array}{l}\text { CCN/IDN } \\
\text { spectrum }\end{array}$ & $\begin{array}{l}\text { Cloud radiative } \\
\text { properties }\end{array}$ \\
\hline $\begin{array}{l}\text { GATOR- } \\
\text { GCMOM } \\
\text { (Global- } \\
\text { through- } \\
\text { urban) }\end{array}$ & $\begin{array}{l}\text { Size-resolved liquid, } \\
\text { ice, graupel, } \\
\text { aerosol core } \\
\text { components in } \\
\text { stratiform subgrid } \\
\text { convective clouds }\end{array}$ & $\begin{array}{l}\text { Prognostic, sectional } \\
(30) \text {, multiple size } \\
\text { distributions (3) }\end{array}$ & $\begin{array}{l}\text { Prognostic, size- and } \\
\text { composition- } \\
\text { dependent } \\
\text { from multiple } \\
\text { aerosol size } \\
\text { distributions }\end{array}$ & $\begin{array}{l}\text { All types of } \\
\text { aerosols treated } \\
\text { for both CCN/IDN }\end{array}$ & $\begin{array}{l}\text { Predicted with } \\
\text { Köhler theory; } \\
\text { sectional } \\
(13-17) \text {; } \\
\text { multiple size } \\
\text { distributions } \\
\text { (1-16) for } \\
\text { both CCN/IDN }\end{array}$ & $\begin{array}{l}\text { Simulated } \\
\text { volume-average } \\
\text { refractive indices } \\
\text { and optical properties } \\
\text { based on MIE } \\
\text { theory and a } \\
\text { dynamic effective } \\
\text { medium approxima- } \\
\text { tion }\end{array}$ \\
\hline $\begin{array}{l}\text { WRF/ } \\
\text { Chem } \\
\text { (Mesoscale) }\end{array}$ & $\begin{array}{l}\text { bulk water } \\
\text { vapor, rain, snow, } \\
\text { cloud ice, cloud water, } \\
\text { and graupel or a } \\
\text { subset of them, } \\
\text { depending on } \\
\text { microphsics } \\
\text { schemes used } \\
\text { in both stratiform } \\
\text { and subgrid } \\
\text { convective clouds }\end{array}$ & $\begin{array}{l}\text { Prognostic, modal, } \\
\text { single size distribu- } \\
\text { tion } \\
\text { (MOSAIC) }\end{array}$ & $\begin{array}{l}\text { Similar } \\
\text { to MIRAGE2 } \\
\text { (MOSAIC) }\end{array}$ & $\begin{array}{l}\text { Similar } \\
\text { to MIRAGE2 } \\
\text { but sectional; } \\
\text { CCN only }\end{array}$ & $\begin{array}{l}\text { Similar } \\
\text { to MIRAGE2 } \\
\text { but sectional, } \\
\text { CCN only }\end{array}$ & $\begin{array}{l}\text { Similar } \\
\text { to MIRAGE2 } \\
\text { but sectional } \\
\text { (MOSAIC) }\end{array}$ \\
\hline $\begin{array}{l}\text { CAM3 } \\
\text { (Global) }\end{array}$ & $\begin{array}{l}\text { Bulk liquid } \\
\text { and ice in both } \\
\text { stratiform and } \\
\text { subgrid convective } \\
\text { clouds }\end{array}$ & $\begin{array}{l}\text { Prognostic in } \\
\text { microphysics } \\
\text { calculation } \\
\text { but prescribed } \\
\text { in sedimentation } \\
\text { and radiation } \\
\text { calculation as } \\
\text { a function } \\
\text { of temperature } \\
\text { by phase } \\
\text { and location }\end{array}$ & $\begin{array}{l}\text { Prescribed } \\
\text { or prognostic } \\
\text { (similar to } \\
\text { MIRAGE2) }\end{array}$ & $\begin{array}{l}\text { All treated } \\
\text { species except } \\
\text { hydrophobic species; } \\
\text { CCN only }\end{array}$ & $\begin{array}{l}\text { Prescribed; } \\
\text { CCN only }\end{array}$ & $\begin{array}{l}\text { Similar to } \\
\text { MIRAGE2 }\end{array}$ \\
\hline $\begin{array}{l}\text { MIRAGE2 } \\
\text { (Global) }\end{array}$ & $\begin{array}{l}\text { Bulk liquid } \\
\text { and ice in both } \\
\text { stratiform and subgrid } \\
\text { convective clouds }\end{array}$ & $\begin{array}{l}\text { Prognostic, modal, } \\
\text { single size distribu- } \\
\text { tion }\end{array}$ & $\begin{array}{l}\text { Prognostic, aerosol } \\
\text { size- and } \\
\text { composition- } \\
\text { dependent, } \\
\text { parameterized }\end{array}$ & $\begin{array}{l}\text { All treated species; } \\
\text { CCN only }\end{array}$ & $\begin{array}{l}\text { Function of } \\
\text { aerosol size and } \\
\text { hygroscopicity } \\
\text { based on Köhler } \\
\text { theory; } \\
\text { CCN only }\end{array}$ & $\begin{array}{l}\text { Prognostic, } \\
\text { parameterized } \\
\text { in terms of cloud } \\
\text { water, ice mass, } \\
\text { and number }\end{array}$ \\
\hline $\begin{array}{l}\text { Caltech } \\
\text { unified GCM } \\
\text { (Global) }\end{array}$ & $\begin{array}{l}\text { Bulk liquid } \\
\text { and ice in } \\
\text { both stratiform } \\
\text { and subgrid } \\
\text { convective clouds }\end{array}$ & $\begin{array}{l}\text { Diagnosed from } \\
\text { predicted cloud } \\
\text { water content; } \\
\text { single size } \\
\text { distribution }\end{array}$ & $\begin{array}{l}\text { constant cloud } \\
\text { droplet number } \\
\text { based on } \\
\text { observations }\end{array}$ & None & None & $\begin{array}{l}\text { Simulated based } \\
\text { on MIE theory } \\
\text { with different } \\
\text { parameterizations } \\
\text { for liquid and } \\
\text { ice clouds }\end{array}$ \\
\hline
\end{tabular}

the same prognostic droplet size treatment as MIRAGE2 in microphysics calculation, but the droplet size treatment is prescribed in sedimentation and radiation calculation as a function of temperature by phase and location (Boville et al., 2006). All five models distinguish large-scale stratiform and subgrid convective clouds but with some differences in their treatments. For example, in GATOR-GCMOM and MIRAGE2, large-scale stratiform clouds can cover a fraction of a grid cell. In WRF/Chem, stratiform clouds have a cloud fraction of 0 or 1 and the aerosols are not affected by sub-grid convective clouds (e.g., Kain-Fritsch option). Neglecting sub-grid cloud treatments may introduce large errors for the horizontal grid resolution greater than 15$\mathrm{km}$. For both resolved and convective clouds in GATORGCMOM, microphysics is explicit and involves growth of water vapor onto discrete size-resolved aerosol particles to form discrete, size-resolved clouds and precipitation (liquid, ice, and graupel), and aerosol inclusions are tracked in each size of each hydrometeor distribution (Jacobson and Kaufman, 2006), whereas other models do not contain such detailed treatments.

Droplet size distribution in both models has a prescribed dispersion so that liquid water content is proportional to number times effective radius cubed. Caltech unified GCM treats bulk liquid and ice with their distributions diagnosed from predicted cloud water content. Among the five models, Caltech unified GCM is the only model that prescribes cloud droplet number, which is predicted in all other four models, although the prescribed cloud droplet number can also be used in the cloud miscrophysics parameterization of 
Rasch and Kristjánsson (1998) in CAM3. Caltech unified GCM assumes a cloud droplet number of 60 and $170 \mathrm{~cm}^{-3}$, respectively, for liquid phase clouds over ocean and land, and $0.06 \mathrm{~cm}^{-3}$ for all ice clouds based on observations (Del Genio et al., 1996). CAM3, MIRAGE2, and WRF/Chem use similar treatments for droplet number, with droplet nucleation parameterized by Abdul-Razzak and Ghan (2000). WRF/Chem-MOSAIC diagnoses the total number activated from the sectional size distribution of the $\mathrm{CCN}$, which is then used to predict the droplet number that has a modal distribution. GATOR treats prognostic, size- and compositiondependent cloud droplet number from multiple aerosol size distributions. While an empirical relationship between sulfate aerosols and CCN is commonly used in most atmospheric models, CCN is calculated from Köhler theory using the aerosol size distribution and hygroscopicity in all models but Caltech unified GCM. MIRAGE 2 and WRF/Chem treat the same CCN composition, except with different size representations. Other than Caltech unified GCM that does not treat $\mathrm{CCN}$ and Ice Deposition Nuclei (IDN), all other four models treat the competition among different aerosol species but the hydrophobic species are not activated in CAM3 since it assumes external-mixture. Among the five models, GATOR-GCMOM is the only model that simulates composition of IDN. For CCN spectrum, MIRAGE 2 and $\mathrm{WRF} / \mathrm{Chem}$ simulate it as a function of aerosol size and hygroscopicity based on Köhler theory. CAM3 uses prescribed CCN spectrum. GATOR predicts spectra of both CCN and IDN with 13-17 sections and 1-16 size distributions for typical applications. MIRAGE 2 and CAM3 use a prognostic parameterization in terms of cloud water and ice mass and number to predict cloud radiative properties. WRF/Chem also uses the same method but with sectional approach. Caltech unified GCM simulates cloud optical properties based on MIE theory and prescribed Gamma distributions for liquid clouds and phase functions of Mishchenko et al. (1996) (Liao et al., 2003). GATOR-GCMOM simulates volume-average cloud refractive indices (RIs) and optical properties based on MIE theory and an iterative dynamic effective medium approximation (IDEMA) to account for multiple $\mathrm{BC}$ inclusions within clouds. The IDEMA is superior to classic effectivemedium approximation that is used by several mixing rules such as the volume-average RI mixing rule, the volume average dielectric constant mixing rule, the Maxwell-Garnett mixing rule, and the Bruggeman mixing rule in two aspects (Jacobson, 2006a). First, the IDEMA accounts for polydispersion of spherical absorbing inclusions within the medium and gives different efficiencies at a given wavelength for a given volume fraction but with different size distributions of absorbing material, as occurs in reality. Second, the IDEMA also accounts for light interactions as a function of size of the material included.

\subsection{Aerosol thermodynamics and dynamics}

Table 5 shows model treatments of aerosol chemistry and microphysics that differ in many aspects. Caltech unified GCM treats aerosol thermodynamics only, the rest of models treat both aerosol thermodynamics and dynamics such as coagulation and new particle formation via homogeneous nucleation. It uses a thermodynamic module, ISORROPIA ("equilibrium" in Greek) of Nenes et al. (1998), for inorganic aerosols with regime equilibrium among sulfate, nitrate, ammonium, sea-salt, and water. Similar to many global models, MIRAGE2 does not treat nitrate; it simulates a simple inorganic aerosol equilibrium involving ammonium sulfate $\left.\left(\mathrm{NH}_{4}\right)_{2} \mathrm{SO}_{4}\right)$ and precursor gases. MOZART4 aerosol module in CAM3 uses regime equilibrium for sulfate, ammonium, and nitrate that accounts for cases with sulfate neutral, rich, and very rich. GATORGCMOM uses the EQUIlibrium SOLVer Version 2 (EQUISOLV II) of Jacobson (1999c) that simulates equilibria of all major inorganic salts and crustal species and that provides the most comprehensive treatments among inorganic aerosol thermodynamic modules used in 3-D models (Zhang et al., 2000). EQUISOLV II has been extended to the Predictor of Nonequilibrium Growth (PNG)-EQUISOLV II to overcome the oscillatory problem in solving the equilibrium and growth at a long time step (150-300 s) (Jacobson, 2005a). In WRF/Chem, different equilibrium modules are used in different aerosol modules. The inorganic aerosol equilibrium modules are the Model for an Aerosol Reacting System (MARS)-version A (MARS-A) of Binkowski and Shankar (1995) in MADE/SORGAM, the Multicomponent Equilibrium Solver for Aerosols (MESA) with a new activity coefficient module Multicomponent Taylor Expansion Method (MTEM) (MESA-MTEM) in MOSAIC, and ISORROPIA in MADRID. Both MARS-A and ISORROPIA use regime equilibrium, whereas MESA-MTEM does not. Sodium chloride is not treated in MARS-A but treated in ISORROPIA and MESA-MTEM. Zhang et al. (2000) evaluated five inorganic aerosol modules used in major 3-D air quality models including MARS-A and EQUISOLV II. They found that MARS-A has the fastest computational speed but it may not be applicable to dry areas with low relative humidities (RHs) and coastal areas. Zhang and Jacobson (2005a) evaluated ISORROPIA and EQUISOLV II in both a box model with 11200 test cases and a 3-D model over continental US. While they found that ISORROPIA gives results that are consistent with those of benchmark and EQUISOLV II under most conditions, larger bias may occur for RHs $\leq 40$ or $\geq 99$ for most species, mainly because of the use of an approximate treatment for water content and solid-liquid equilibrium in the mutual deliquescence region at moderate and low RHs (Ansari and Pandis, 1999; Zaveri et al., 2008) and errors in activity coefficients used at very high RHs. An improved ISORROPIA (version 1.7) has been developed and implemented in WRF/Chem- 
Table 5. Treatments of Aerosol Chemistry and Microphysics of Online Models.

\begin{tabular}{|c|c|c|c|c|c|c|}
\hline $\begin{array}{l}\text { Model } \\
\text { System }\end{array}$ & $\begin{array}{l}\text { Inorganic } \\
\text { aero. thermodynamic } \\
\text { equilibrim }\end{array}$ & $\begin{array}{l}\text { Secondary } \\
\text { organic } \\
\text { aerosol } \\
\text { formation }\end{array}$ & $\begin{array}{l}\text { New particle } \\
\text { Formation }\end{array}$ & $\begin{array}{l}\text { Condensation } \\
\text { of gases on } \\
\text { aerosols }\end{array}$ & Coagulation & $\begin{array}{l}\text { Gas/particle } \\
\text { mass transfer }\end{array}$ \\
\hline $\begin{array}{l}\text { GATOR- } \\
\text { GCMOM } \\
\text { (Global- } \\
\text { through- } \\
\text { urban) }\end{array}$ & $\begin{array}{l}\text { EQUISOLV II, } \\
\text { major inorganic salts } \\
\text { and crustal } \\
\text { species }\end{array}$ & $\begin{array}{l}\text { Condensation; } \\
\text { Dissolution } \\
\text { based on } \\
\text { Henry's law } \\
\text { (10-40 classes VOCs) }\end{array}$ & $\begin{array}{l}\text { Binary homogeneous } \\
\text { nucleation of } \\
\mathrm{H}_{2} \mathrm{SO}_{4} \text { and } \mathrm{H}_{2} \mathrm{O} \\
\text { of Vehkamäki et al. } \\
\text { (2002), T- and } \mathrm{RH}- \\
\text { dependent; } \\
\text { Ternary nucleation } \\
\text { from Napari et al. } \\
(2002)\end{array}$ & $\begin{array}{l}\text { Dynamic } \\
\text { condensation of } \\
\text { all condensible } \\
\text { species based on } \\
\text { growth law } \\
\text { (e.g., } \mathrm{H}_{2} \mathrm{SO}_{4} \text {, VOCs) } \\
\text { using the } \\
\text { Analytical } \\
\text { Predictor } \\
\text { of Condensation } \\
\text { (APC) with the } \\
\text { moving } \\
\text { center scheme }\end{array}$ & $\begin{array}{l}\text { Sectional, } \\
\text { multiple size } \\
\text { distributions, } \\
\text { Brownian diffusion, } \\
\text { turbulent shear, } \\
\text { turbulent inertial } \\
\text { motion, } \\
\text { gravitational settling, } \\
\text { diffusiophoresis, } \\
\text { thermophoresis, } \\
\text { electric charge, } \\
\text { also accounts for } \\
\text { van der Waals } \\
\text { and viscous forces, } \\
\text { and fractal geometry }\end{array}$ & $\begin{array}{l}\text { Dynamic approach } \\
\text { with a long time } \\
\text { step }(150-300 \mathrm{~s}) \\
\text { (PNG-EQUISOLV II) } \\
\text { for all } \\
\text { treated species }\end{array}$ \\
\hline $\begin{array}{l}\text { WRF/ } \\
\text { Chem } \\
\text { (Mesoscale) }\end{array}$ & $\begin{array}{l}\text { MARS-A } \\
\text { (SORGAM) } \\
\text { MESA-MTEM } \\
\text { (MOSAIC) } \\
\text { ISORROPIA } \\
\text { (MADRID) }\end{array}$ & $\begin{array}{l}\text { Reversible } \\
\text { absorption } \\
\text { (8 classes VOCs) } \\
\text { based on } \\
\text { smog-chamber } \\
\text { data (SORGAM) } \\
\text { Absorption } \\
\text { (MADRID1) } \\
\text { and combined } \\
\text { absorption and } \\
\text { dissolution } \\
\text { (MADRID2). } \\
\text { No SOA treatment } \\
\text { in MOSAIC }\end{array}$ & $\begin{array}{l}\text { Binary } \\
\text { homogeneous } \\
\text { nucleation of } \\
\mathrm{H}_{2} \mathrm{SO}_{4} \text { and } \\
\mathrm{H}_{2} \mathrm{O} \text { of } \\
\text { Kulmala et al. } \\
\text { (1998 b) (SORGAM) } \\
\text { and of McMurry, } \\
\text { and Friedlander, } \\
\text { (1979) (MADRID); } \\
\text { T- and } \\
\text { RH-dependent; } \\
\text { sectional; } \\
\text { different equations } \\
\text { in different } \\
\text { aero modules }\end{array}$ & $\begin{array}{l}\text { Dynamic } \\
\text { condensation of } \\
\mathrm{H}_{2} \mathrm{SO}_{4} \text { and } \\
\text { VOCs using the } \\
\text { modal approach of } \\
\text { Binkowski and } \\
\text { Shankar (1995) } \\
\text { (SORGAM), of } \\
\mathrm{H}_{2} \mathrm{SO}_{4} \text {, } \\
\text { MSA, and } \mathrm{NH}_{3} \\
\text { using the Adaptive } \\
\text { Step Time-split } \\
\text { Explicit } \\
\text { Euler Method } \\
\text { (ASTEEM) method } \\
\text { (MOSAIC), and of } \\
\text { volatile inorganic } \\
\text { species using the } \\
\text { APC with moving } \\
\text { center scheme } \\
\text { (MADRID) }\end{array}$ & $\begin{array}{l}\text { Modal/Sectional } \\
\text { (MADE/SORGAM, } \\
\text { MOSAIC), } \\
\text { single size } \\
\text { distribution, } \\
\text { fine modes only }\end{array}$ & $\begin{array}{l}\text { 1. Full equilibrium } \\
\text { for } \mathrm{HNO}_{3} \text { and } \\
\mathrm{NH}_{3} \text { in } \\
\text { MADE/SORGAM } \\
\text { and } \\
\text { all species } \\
\text { in MADRID } \\
\text { 2. Dynamic for } \\
\mathrm{H}_{2} \mathrm{SO}_{4} \text { in } \\
\mathrm{MADE} / S O R G A M \text {; } \\
\text { Dynamic for } \\
\text { all species } \\
\text { in MOSAIC } \\
\text { and MADRID } \\
\text { 3. Hybrid in } \\
\text { MADRID }\end{array}$ \\
\hline $\begin{array}{l}\text { CAM3 } \\
\text { (Global) }\end{array}$ & $\begin{array}{l}\text { MOZART4 with } \\
\text { regime equili. for } \\
\text { sulfate, nitrate, } \\
\text { and ammonium }\end{array}$ & $\begin{array}{l}\text { Prescribed SOA } \\
\text { yield for } \alpha \text {-pinene, } \\
\text { n-butane, and toluene }\end{array}$ & None & $\begin{array}{l}\text { Instantaneous } \\
\text { condensation of } \\
\text { inorganic species }\end{array}$ & None & $\begin{array}{l}\text { Full equilibrium } \\
\text { involving }\left(\mathrm{NH}_{4}\right)_{2} \mathrm{SO}_{4} \\
\text { and } \mathrm{NH}_{4} \mathrm{NO}_{3}\end{array}$ \\
\hline $\begin{array}{l}\text { MIRAGE2 } \\
\text { (Global) }\end{array}$ & $\begin{array}{l}\text { Sulfate assumed } \\
\text { to be }\left(\mathrm{NH}_{4}\right)_{2} \mathrm{SO}_{4}, \\
\text { no nitrate }\end{array}$ & $\begin{array}{l}\text { Prescribed SOA } \\
\text { yield for monoter- } \\
\text { penes }\end{array}$ & $\begin{array}{l}\text { Binary homogeneous } \\
\text { nucleation of } \\
\mathrm{H}_{2} \mathrm{SO}_{4} \text { and } \\
\mathrm{H}_{2} \mathrm{O} \text { of } \\
\text { Harrington and Krei- } \\
\text { denweis (1998); } \\
\text { T- and RH-dependent }\end{array}$ & $\begin{array}{l}\text { Dynamic } \\
\text { condensation of } \\
\mathrm{H}_{2} \mathrm{SO}_{4} \\
\text { and MSA based } \\
\text { on Fuchs and Sutugin } \\
\text { growth law }\end{array}$ & $\begin{array}{l}\text { Modal, single size } \\
\text { distribution, } \\
\text { fine modes } \\
\text { only; Brownian } \\
\text { diffusion }\end{array}$ & $\begin{array}{l}\text { Dynamic approach } \\
\text { for } \mathrm{H}_{2} \mathrm{SO}_{4} \\
\text { and MSA }\end{array}$ \\
\hline $\begin{array}{l}\text { Caltech } \\
\text { unified GCM } \\
\text { (Global) }\end{array}$ & $\begin{array}{l}\text { ISORROPIA with } \\
\text { regime equili. for } \\
\text { sulfate, nitrate, } \\
\text { ammonium, sea-salt, } \\
\text { and water }\end{array}$ & $\begin{array}{l}\text { Reversible } \\
\text { Absorption for } \\
5 \text { biogenic } \\
\text { VOC classes }\end{array}$ & None & None & None & $\begin{array}{l}\text { Full equilibrium } \\
\text { involving }\left(\mathrm{NH}_{4}\right)_{2} \mathrm{SO}_{4} \\
\text { and } \mathrm{NH}_{4} \mathrm{NO}_{3}\end{array}$ \\
\hline
\end{tabular}

MADRID. MESA (Zaveri et al., 2005a) is designed to efficiently solve the complex solid-liquid partitioning within each aerosol size bin using a pseudo-transient continuation technique. MESA and EQUISOLV II are evaluated against the AIM Model III and they give overall similar results in terms of both mass growth factors and performance statistics relative to the AIM Model III for the 16 cases tested in Zaveri et al. (2005a). A major factor contributing to the dif- ferences in simulated results from various aerosol thermodynamic modules is the activity coefficients used in these modules. For example, EQUISOLV II and ISORROPIA account for temperature-dependence for all activity coefficients when such information are available, the activity coefficients used in MESA, however, are limited for $298 \mathrm{~K}$, which may introduce errors for their applications for upper tropospheric and stratospheric conditions (e.g., the tropical tropopause 
where the temperature may fall below $200 \mathrm{~K}$ and activity coefficients of species may deviate largely from their values at $298 \mathrm{~K}$ ). While EQUISOLV II provides a generic code for aerosol thermodynamic calculation, most other modules (e.g., ISORROPIA and MESA) require non-trivial efforts to expand the system of equations for more species and/or other temperatures and/or the re-development of some parameterizations used.

Several major approaches have been used in 3-D models to simulate secondary organic aerosol (SOA) including saturation or fixed aerosol yield (e.g., Pandis et al., 1992), absorption/adsorption (Pankow, $1994 \mathrm{a}, \mathrm{b}$ ), dissolution (Jacobson, 1997a), dynamic condensation (Jacobson, 1997a), and combination of absorption and dissolution (Pun et al., 2002; Griffin et al., 2002). Both CAM3 and MIRAGE2 use prescribed aerosol yields for a few condensable volatile organic compounds (VOCs), which is the simplest, computationally most efficient approach but it does not provide a mechanistic understanding of SOA formation. GATOR-GCMOM simulates SOA formation from 10-40 classes VOCs via condensation and dissolution based on Henry's law. Caltech unified GCM simulates the formation of SOA based on a reversible absorption of 5 classes of biogenic VOCs and neglect that from anthropogenic VOCs. In MADE/SORGAM in $\mathrm{WRF} / \mathrm{Chem}$, SOA formation via the reversible absorption of 8 classes of VOCs is simulated based on smog-chamber data of Odum et al. (1997) and Griffin et al. (1999). The same approach for SOA modeling has been used in an offline version of MOSAIC, which, however, has not been incorporated into WRF/Chem for 3-D applications. Two approaches are used to simulate SOA formation in WRF/ChemMADRID (Zhang et al., 2004). MADRID 1 uses an absorptive approach for 14 parent VOCs (2 anthropogenic, and 12 biogenic) and 38 SOA species (4 anthropogenic, and 34 biogenic). MADRID 2 combines absorption and dissolution approaches to simulate an external mixture of 42 hydrophilic and hydrophobic VOCs, which are grouped into 10 surrogate compounds based on their affinity for water, origin, number of carbon, volatility, and dissociation properties (Pun et al., 2002). MADRID 1 has been upgraded to Sesqui-MADRID (MADRID 1.5) and now treats phase separation (i.e., a relatively hydrophilic phase and a relatively hydrophobic phase) within the organic particulate phase when thermodynamically favorable (Pun et al., 2008). MADRID 2 has been modified to be compatible with any gas-phase mechanism (Pun et al., 2006). A variation of MADRID 2 that is computationally efficient has been incorporated into the Mesoscale Nonhydrostatic Chemistry (Meso-NH-C) model of Tulet et al. (2003) that couples meteorology and chemistry online (Tulet et al., 2005, 2006). Simulated SOA concentrations by most 3-D models are, however, lower than observations for several reasons. For example, these models use the yields for aromatics and monoterpene oxidation under high $\mathrm{NO}_{\mathrm{x}}$ conditions (e.g., Odum et al., 1997; Griffin et al., 1999; Ng et al., $2007 \mathrm{a}, \mathrm{b}$ ). Some SOA precursors in these models may be missing (e.g., isoprene SOA is not simulated in MADESORGAM), which have been shown to be important at both global and regional scales (e.g., Henze and Seinfeld, 2006; Zhang et al., 2007b).

New particle formation via binary homogeneous nucleation is simulated in all models except for CAM3, and that via ternary nucleation based on Napari et al. (2002) is only simulated in GATOR-GCMOM. Different models use different equations that account for the dependence of new particle formation rates in different ways on number concentration or critical vapor pressure of $\mathrm{H}_{2} \mathrm{SO}_{4}$, critical new particle formation rate, temperature, and RH. The binary parameterization of Harrington and Kreidenweis (1998) used in MIRAGE2 is based on the calculations of nucleation rates performed by Jaecker-Voirol and Mirabel (1989), which calculates the absolute nucleation rates based on heteromolecular homogeneous nucleation theory of the $\mathrm{H}_{2} \mathrm{SO}_{4}-\mathrm{H}_{2} \mathrm{O}$ system. The parameterizations of Kulmala et al. (1998) used in MADE/SORGRAM, Wexler et al. (1994) used in MOSAIC in WRF/Chem, and Vehkamäki et al. (2002) used in GATOR-GCMOM are derived based on the classical binary homogeneous nucleation model that simulates nucleation kinetics and accounts for hydration. The parameterization of Kulmala et al. (1998) predicts binary nucleation rates up to 2-3 orders of magnitude lower than those predicted by most other binary nucleation parameterizations due to the fact that its derivation contains mistakes in the kinetic treatment for hydrate formation (Vehkamäki et al., 2002; Noppel et al., 2002; Zhang and Jacobson, 2005b). The parameterization of McMurry and Friedlander (1979) in WRF/ChemMADRID uses an approach that simulates gas-to-particle conversion between nucleation of new particles and condensation on existing particles, which is a more realistic approach than that based on the absolute prediction of a nucleation rate. While CAM3 assumes instantaneous condensation of inorganic species, other models simulate dynamic condensation of condensable species based on similar growth laws but with different numerical condensational algorithms. For example, GATOR-GCMOM and WRF/Chem-MADRID use the Analytical Predictor of Condensation (APC) with the moving center scheme, WRF/Chem-MADE/SORGAM uses the modal approach of Binkowski and Shankar (1995), WRF/Chem-MOSAIC (version 2.2) uses the Adaptive Step Time-split Explicit Euler Method (ASTEEM) method, which has recently been updated to the Adaptive Step Time-split Euler Method (ASTEM) method to reduce the stiffness more effectively using several methods and to allow the use of longer time step $(\sim 100 \mathrm{~s})$ in an offline version of MOSAIC (Zaveri et al., 2008). Coagulation is currently not treated in CAM3 but simulated with a modal approach with several lognormally-distributed modes in MIRAGE2, a sectional approach with a number of size sections in GATOR-GCMOM, and both approaches in WRF/Chem (e.g., MADE/SORGAM uses the modal approach; MOSIAC and MADRID use the sectional approach). Different from other model treatments, 
GATOR accounts for van der Waals and viscous forces, and fractal geometry in simulating coagulation among particles from multiple size distributions (Jacobson and Seinfeld, 2004). While van der Waals and fractal geometry may enhance coagulation, viscous forces tend to retard the rate of van der Waals force enhancement in the continuum regime.

Three approaches are typically used to simulate gas/particle mass transfer in 3-D air quality models: full equilibrium, dynamic, and hybrid. No condensation equation is explicitly solved in the full equilibrium approach (although a weighting factor based on condensational growth law may be used to distribute the transferred mass material from gas to particulate phase over the particle size distribution), whereas condensation is explicitly solved for all particles in the dynamic approach and for particles with diameter greater than a threshold (a typical threshold value of 1 to $2.5 \mu \mathrm{m}$ is assumed) in the hybrid approach. In such cases, condensation is a sub-process of gas/particle mass transfer. For gas/particle mass transfer, CAM3 and Caltech unified GCM use the simplest full equilibrium approach. MIRAGE2 uses a dynamic approach for $\mathrm{H}_{2} \mathrm{SO}_{4}$ and MSA. GATOR-GCMOM uses a computationally efficient dynamic approach with a long time step (150-300 s) (PNG-EQUISOLV II) for all treated species (Jacobson, 2005a). In WRF/Chem, a full equilibrium is used for $\mathrm{HNO}_{3}$ and $\mathrm{NH}_{3}$ in MADE/SORGAM. A dynamic approach is used for $\mathrm{H}_{2} \mathrm{SO}_{4}$ in MADE/SORGAM and all species in MOSAIC. In the dynamic approach of MOSAIC, ASTEEM is coupled with MESA to solve the dynamic gas-aerosol partitioning over multiple size bins. Characteristic times for semi-volatile trace gases to reach equilibrium can vary significantly (by up to several orders of magnitude) among particles with different sizes, making the coupled system of ordinary differential equations for gas-aerosol mass transfer extremely stiff. ASTEEM is developed to reduce the stiffness of the system and improve computational efficiency by allowing the solver to take longer time steps with only a relatively small loss in accuracy. MADRID offers three approaches: full equilibrium, dynamic, and hybrid; their performance has been evaluated in Zhang et al. (1999) and Hu et al. (2008). The box MADRID tests of $\mathrm{Hu}$ et al. (2008) have shown that the bulk equilibrium approach is computationally-efficient but fails to predict the distribution of semi-volatile species (e.g., ammonium, chloride, and nitrate) because of the equilibrium and internal mixture assumptions. The hybrid approach exhibits the same problem for some cases as the bulk equilibrium approach since it assumes bulk equilibrium for fine particles. The kinetic approach predicts the most accurate solutions with variable computational efficiencies depending on whether a small time step is required.

\subsection{Aerosol-cloud interactions and cloud processes}

Table 6 summarizes the treatments of aerosol-cloud interactions and cloud processes used in the five models. Water uptake is a very important process affecting calculations of both direct and indirect forcing. CAM3 simulates bulk equilibrium with RH for external mixtures only. MIRAGE 2 and WRF/Chem-MOSAIC simulate hygroscopic growth in equilibrium with RH based on Köhler theory. Water uptake is calculated as a function of RH, the mean dry radius, the relative contributions of each aerosol component to the total particle hygroscopicity, and the aerosol water content from previous time step. Aerosol water content in GATOR-GCMOM is calculated based on discrete sizeresolved equilibrium using the Zdanovskii-Stokes-Robinson (ZSR) method (Zdanovskii, 1948; Stokes and Robinson, 1966); it simulates the mutual deliquescent RH (MDRH). The ZSR method is also used to simulate aerosol water uptake in Caltech unified GCM. No hysteresis effect is accounted for in CAM3 and Caltech unified GCM, but it is treated in other models.

Activation of aerosol particles that can behave as $\mathrm{CCN}$ to produce cloud droplets is an important process affecting simulations of aerosol-cloud interactions, and aerosol direct and indirect forcing. CAM3 uses empirical, prescribed activated mass fraction for bulk CCN. MIRAGE 2 and WRF/Chem use a mechanistic, parameterized activation module that is based on Köhler theory to simulate bulk CCN. In Köhler theory, the number of particles activated is expressed in terms of supersaturation $S$, which is primarily determined by aerosol properties (i.e., number, size, and hygroscopicity) and updraft velocity. Important parameters for activation such as the peak supersaturation, $S_{\max }$, mass of activated aerosols, and the size of the smallest aerosol activated are calculated using the parameterizations of Abdul-Razzak et al. (1998) and Abdul-Razzak and Ghan (2000) that relate the aerosol number activated directly to fundamental aerosol properties. The effects of Kelvin and Rault's law for liquid activation are partially taken into account in those parameterizations. GATOR-GCMOM also simulates a mechanistic, size- and composition-resolved CCN/IDN based on Köhler theory. At high-resolution regional scales, the saturation ratios at equilibrium $\left(S^{\prime}\right)$ are determined from Köhler theory as a function of aerosol particle composition and size, accounting for the Kelvin effect and Raoult's law for liquid activation and the Kelvin effect for ice activation. Aerosol composition of a given size affects the Kelvin term through the surface tension and Raoult's law through the molality term (Jacobson et al., 2007). On the global scale and coarse regional scales, the water vapor available for condensation is determined from cumulus and stratus parameterizations. The cumulus parameterization treats subgrid clouds, and aerosol particles are convected within each of these clouds. Liquid and ice from the cumulus/stratus parameterization are evaporated/sublimated and regrown onto size- and composition- 
Table 6. Treatments of Aerosol-Cloud Interactions and Cloud Processes of Online Models.

\begin{tabular}{|c|c|c|c|c|c|c|}
\hline $\begin{array}{l}\text { Model } \\
\text { System }\end{array}$ & $\begin{array}{l}\text { Aerosol } \\
\text { water } \\
\text { uptake }\end{array}$ & $\begin{array}{l}\text { Aerosol } \\
\text { activation } \\
\text { aero-CCN/IDN }\end{array}$ & $\begin{array}{l}\text { In-cloud } \\
\text { scavenging }\end{array}$ & $\begin{array}{l}\text { Below-cloud } \\
\text { scavenging }\end{array}$ & $\begin{array}{l}\text { Coagulation } \\
\text { involving } \\
\text { hydrometeor }\end{array}$ & $\begin{array}{l}\text { Sedimentation } \\
\text { of aerosols } \\
\text { and cloud } \\
\text { droplets }\end{array}$ \\
\hline $\begin{array}{l}\text { GATOR- } \\
\text { GCMOM } \\
\text { (Global- } \\
\text { through- } \\
\text { urban) }\end{array}$ & $\begin{array}{l}\text { Size-resolved } \\
\text { Equilibrium with } \\
\text { RH; ZSR } \\
\text { equation; } \\
\text { simulated } \\
\text { MDRH; } \\
\text { Hysteresis } \\
\text { is treated }\end{array}$ & $\begin{array}{l}\text { Mechanistic, } \\
\text { size- and } \\
\text { composition- } \\
\text { resolved } \\
\text { CCN/IDN } \\
\text { based on } \\
\text { Köhler theory; } \\
\text { accounting } \\
\text { for the Kelvin } \\
\text { effect and } \\
\text { Raoult's law } \\
\text { for liquid } \\
\text { activation } \\
\text { and the } \\
\text { Kelvin effect } \\
\text { for ice } \\
\text { activation }\end{array}$ & $\begin{array}{l}\text { Size-resolved } \\
\text { aerosol } \\
\text { activation; } \\
\text { nucl. } \\
\text { scavenging } \\
\text { (rainout), } \\
\text { autoconversion } \\
\text { for size-resolved } \\
\text { cloud droplets; } \\
\text { precip. rate } \\
\text { dependent on } \\
\text { aerosol size } \\
\text { and composition }\end{array}$ & $\begin{array}{l}\text { Size-resolved } \\
\text { aerosol-hydrometeor } \\
\text { coag. (washout), } \\
\text { calculated precip. } \\
\text { rate dependent } \\
\text { on aerosol } \\
\text { size and } \\
\text { composition }\end{array}$ & $\begin{array}{l}\text { Size-resolved } \\
\text { coagulation } \\
\text { between } \\
\text { hydrometeors } \\
\text { and between } \\
\text { all aerosols } \\
\text { and all } \\
\text { hydrometeors }\end{array}$ & $\begin{array}{l}\text { Two-moment } \\
\text { discrete } \\
\text { size-dependent } \\
\text { sedimentation } \\
\text { for all } \\
\text { aerosol } \\
\text { particles and } \\
\text { hydrometeors } \\
\text { (mass and number) } \\
\text { that vary } \\
\text { with altitude; } \\
\text { sedimentation } \\
\text { below cloud } \\
\text { leads to } \\
\text { shrinkage } \\
\text { as a function } \\
\text { of drop size }\end{array}$ \\
\hline $\begin{array}{l}\text { WRF/ } \\
\text { Chem } \\
\text { (Mesoscale) }\end{array}$ & $\begin{array}{l}\text { The same } \\
\text { as MIRAGE2 } \\
\text { but sectional } \\
\text { (MOSAIC) }\end{array}$ & $\begin{array}{l}\text { The same } \\
\text { as MIRAGE2 } \\
\text { but sectional } \\
\text { (MOSAIC); } \\
\text { bulk CCN only }\end{array}$ & $\begin{array}{l}\text { The same } \\
\text { as MIRAGE2 } \\
\text { but sectional }\end{array}$ & $\begin{array}{l}\text { Similar to } \\
\text { MIRAGE2 } \\
\text { but sectional }\end{array}$ & $\begin{array}{l}\text { Similar to } \\
\text { MIRAGE2 } \\
\text { but sectional }\end{array}$ & $\begin{array}{l}\text { Two-moment } \\
\text { sedimentation } \\
\text { for aerosol } \\
\text { particles } \\
\text { (mass and number) } \\
\text { at surface; } \\
\text { sedimentation } \\
\text { for all } \\
\text { hydrometeors } \\
\text { or a subset } \\
\text { of them, } \\
\text { depending on } \\
\text { microphysics } \\
\text { schemes }\end{array}$ \\
\hline $\begin{array}{l}\text { CAM3 } \\
\text { (Global) }\end{array}$ & $\begin{array}{l}\text { For external } \\
\text { mixtures only, } \\
\text { bulk } \\
\text { equilibrium with } \\
\text { RH, no } \\
\text { hysteresis }\end{array}$ & $\begin{array}{l}\text { Empirical, } \\
\text { prescribed } \\
\text { activated mass } \\
\text { fraction; } \\
\text { bulk CCN only }\end{array}$ & $\begin{array}{l}\text { Prescribed } \\
\text { bulk activation, } \\
\text { autoconversion, } \\
\text { precip. rate } \\
\text { independent on } \\
\text { aerosols }\end{array}$ & $\begin{array}{l}\text { Prescribed } \\
\text { bulk scav. } \\
\text { efficiency, } \\
\text { no-size } \\
\text { dependence }\end{array}$ & None & $\begin{array}{l}\text { Bulk } \\
\text { cloud/ice } \\
\text { sedimentation; } \\
\text { sedimentation } \\
\text { below cloud } \\
\text { leads to } \\
\text { complete } \\
\text { evaporation/sublimation }\end{array}$ \\
\hline $\begin{array}{l}\text { MIRAGE2 } \\
\text { (Global) }\end{array}$ & $\begin{array}{l}\text { Bulk } \\
\text { equilibrium } \\
\text { with RH } \\
\text { based on } \\
\text { Köhler theory, } \\
\text { Hysteresis } \\
\text { is treated }\end{array}$ & $\begin{array}{l}\text { Mechanistic, } \\
\text { parameterized } \\
\text { modal activation } \\
\text { based on } \\
\text { Köhler theory; } \\
\text { bulk CCN only; } \\
\text { partially } \\
\text { accounting } \\
\text { for the } \\
\text { Kelvin effect } \\
\text { and Raoult's } \\
\text { law for } \\
\text { liquid } \\
\text { activation }\end{array}$ & $\begin{array}{l}\text { Modal } \\
\text { activation } \\
\text { (nucleation) } \\
\text { scavenging, } \\
\text { Brownian } \\
\text { diffusion } \\
\text { (for activated parti- } \\
\text { cles), } \\
\text { autoconversion } \\
\text { and collection } \\
\text { for bulk } \\
\text { cloud droplets, } \\
\text { precip. rate } \\
\text { independent } \\
\text { of aerosols }\end{array}$ & $\begin{array}{l}\text { Calculated } \\
\text { modal } \\
\text { scavenging coeff. } \\
\text { using a } \\
\text { parameterization } \\
\text { of the } \\
\text { collection } \\
\text { efficiency } \\
\text { of aerosol } \\
\text { particles } \\
\text { by rain } \\
\text { drops, } \\
\text { with size } \\
\text { dependence }\end{array}$ & $\begin{array}{l}\text { Modal } \\
\text { coagulation } \\
\text { between } \\
\text { cloud droplets, } \\
\text { between } \\
\text { cloud droplets } \\
\text { and precipitating } \\
\text { particles, } \\
\text { and between } \\
\text { aerosol and } \\
\text { precipitating } \\
\text { particles }\end{array}$ & $\begin{array}{l}\text { Two-moment } \\
\text { sedimentation } \\
\text { for aerosol } \\
\text { particles } \\
\text { (mass and number) } \\
\text { at the } \\
\text { surface; no } \\
\text { sedimentation } \\
\text { for cloud } \\
\text { droplets/ices, } \\
\text { cloud-borne } \\
\text { and ice-borne } \\
\text { aerosol } \\
\text { particles. }\end{array}$ \\
\hline $\begin{array}{l}\text { Caltech } \\
\text { unified } \\
\text { GCM } \\
\text { (Global) }\end{array}$ & $\begin{array}{l}\text { Bulk } \\
\text { equilibrium, } \\
\text { ZSR equation, } \\
\text { no hysteresis }\end{array}$ & None & $\begin{array}{l}\text { Bulk } \\
\text { autoconversion; } \\
\text { nucl. scavenging } \\
\text { with prescribed } \\
\text { scavenging } \\
\text { coefficient } \\
\text { for sea-salt } \\
\text { and dust and } \\
\text { a first-order } \\
\text { precipitation- } \\
\text { dependent } \\
\text { parameterization } \\
\text { for other } \\
\text { aerosols; precip. } \\
\text { rate independent } \\
\text { of aerosols }\end{array}$ & $\begin{array}{l}\text { First-order } \\
\text { precipitation- } \\
\text { dependent bulk } \\
\text { parameterization; } \\
\text { calculated } \\
\text { scavenging } \\
\text { efficiency } \\
\text { with size } \\
\text { dependence }\end{array}$ & None & $\begin{array}{l}\text { Implicitly } \\
\text { accounted } \\
\text { for in a } \\
\text { parameterization } \\
\text { of the } \\
\text { limiting } \\
\text { autoconversion } \\
\text { rate }\end{array}$ \\
\hline
\end{tabular}


resolved aerosol particles (Jacobson, 2003c). One difference between the treatments in GATOR-GCMOM and MIRAGE2 is that the MIRAGE activation parameterization neglects size-dependence of the water vapor diffusivity coefficient and mass transfer coefficient, which may lead to an underestimation of cloud droplet number concentration. In addition, it does not treat the kinetic effect (i.e., mass transfer limitation) for larger particles for which the equilibrium Köhler theory may be inappropriate. Such size-dependence and kinetic effects are accounted for in GATOR-GCMOM. Aerosol-cloud interaction is currently not treated in Caltech unified GCM.

Aerosols are removed through dry deposition in the absence of hydrometerors and through wet deposition following in- and below- cloud scavenging, in addition to be activated as CCN to form cloud droplets. After activation, cloud droplets (and cloudborne aerosol particles) are removed via autoconversion (i.e., the collision/coalescence of cloud drops to become rain drops and get into precipitation) and via collection/accretion by (existing) precipitation (rain, snow, graupel). CAM3 assumes that in-cloud scavenging occurs via prescribed activation and autoconversion. Caltech unified GCM treats autoconversion and nucleation scavenging with prescribed scavenging coefficient for sea-salt and dust and a first-order precipitation-dependent parameterization for other aerosols. The in-cloud scavenging processes in MIRAGE2 and WRF/Chem include activation (nucleation) scavenging, Brownian diffusion (for activated particles), autoconversion, and collection. The dependence of autoconversion on droplet number is neglected in both models. All those processes are included for discrete size-resolved clouds in GATOR-GCMOM. Note that autoconversion is treated somewhat differently in GATOR-GCMOM as in other models because of differences in the cloud treatments. Cloud droplets are treated to be size-resolved in GATOR-GCMOM but bulk in other models. Consequently, other models treat autoconversion for bulk cloud droplets whereas GATORGCMOM treats coagulation for discrete size-resolved cloud droplets into rain drops/ice crystals (which is analogous to autoconversion for bulk clouds). The dependence of precipitation rates on discretely size resolved aerosols via nucleation scavenging and impact scavenging is taken into account in GATOR-GCMOM, but are neglected in other models. The main differences between treatments of cloud-processing of aerosols in GATOR-GCMOM and other models are (1) other models treat removal of aerosols as an empirical function of the rainfall rate without physical interactions of size-resolved aerosols with size-resolved rainfall, and (2) other models do not always track all the aerosol components that the clouds formed on within size resolved cloud drops.

For below-cloud scavenging, CAM3 prescribes scavenging efficiencies. MIRAGE2 and WRF/Chem calculate a scavenging coefficient (=scavenging rate/precipitation rate) using a parameterization of the collection efficiency of aerosol particles by rain drops (due to convective Brownian diffusion and gravitational/inertial capture). Caltech unified GCM assumes the first-order precipitation-dependent scavenging parameterization, whereas GATOR-GCMOM simulates discrete size-resolved aerosol-hydrometeor coagulation (washout). The dependence of below-cloud scavenging and precipitation rates on aerosol size and composition is accounted for in GATOR-GCMOM but either partially (e.g., Caltech unified GCM calculates size-dependent scavenging efficiency) or completely neglected in other models. Among the five models, GATOR-GCMOM is the only model that treats coagulation between different size sections from different size distributions for various hydrometeors (e.g., liquid-liquid, liquid-ice, liquid-graupel, ice-ice, ice-graupel, graupel-graupel) and that between aerosols and hydrometeors. MIRAGE2 and WRF/Chem simulate coagulation between cloud droplets, between cloud droplets and precipitating particles, and between aerosol and precipitating particles for one size distribution of each type of hydrometeors.

Sedimentation refers to the layer-by-layer sinking of aerosol particles, hydrometeor particles (e.g., cloud drops/ice, cloud-borne and ice-borne particles, and precipitating particles) as a function of their sizes. Sedimentation of cloud droplets and precipitating particles to the ground in the bottom layer is precipitation if a model treats sedimentation layer by layer. GATOR-GCMOM treats layer by layer sedimentation of discrete size-resolved aerosol particles, liquid, ice, graupel particles, and their chemical inclusions with fall speeds for both mass and number concentrations (i.e., so-called two-moment methods) as a function of their sizes. As droplets fall below clouds, they shrink as a function of size. Some may completely evaporate, releasing their aerosol cores back to the air. Some may hit the ground as precipitation. CAM3 treats sedimentation of bulk mass and number concentrations of liquid and ice particles, each with a single fall speed that is calculated as a function of a mass-weighted effective radius of ice particles (Boville et al., 2006). For bulk ice, the effective radius is calculated for a size distribution that is assumed to be a function of temperature only. For bulk liquid, no size distribution is assumed; the effective radius is determined from the bulk liquid water mass and the total number concentration of particles. Liquid and ice particles falling from one layer to the next within a cloud do not coagulate as a function of size. All hydrometeors falling below a cloud are evaporated/sublimated completely without releasing aerosol cores. No precipitation resulted from sedimentation unless the cloud exists in the bottom layer (Note that precipitation is calculated as a separate autoconversion in CAM3). MIRAGE2 also treats two-moment sedimentation for aerosol particles, but it does not treat sedimentation of cloud droplet/ice and cloud-born and ice-born particles. Depending on schemes for cloud microphysics used in WRF/Chem, the sedimentation process is treated for all the hydrometeor categories treated or a subset of them for both mass and number concentrations (Skamarock et 
al., 2005). Droplet sedimentation is not explicitly treated in Caltech unified GCM because it does not resolve the scales of vertical motion relevant to sedimentation; it is, however, implicitly accounted for by parameterizing the limiting autoconversion rate as a decreasing function of the large scale vertical velocity (Del Genio et al., 1996). A discrete cloud size distribution as it is used in GATORGCMOM is necessary to realistically simulate all cloud microphysical processes (e.g., condensation/evaporation, deposition/sublimation, collision-coalescence, contact freezing, rainout, washout, sedimentation) from first principles rather than parameterizations. The droplet sedimentation treatment in CAM3 is not physical and prevents an accurate simulation of the physical feedbacks of aerosol particles to climate.

\section{Case studies}

To illustrate the importance of the feedbacks discussed previously, several case studies on some of the feedbacks using some of the aforementioned models are provided below. These include the feedbacks of aerosols to PBL meteorology by WRF/Chem-MADRID, the feedbacks of aerosols to wind fields and precipitation by GATOR-GCMOM, and the feedbacks of aerosol/cloud to indirect aerosol radiative forcing by MIRAGE2 and CAM3. These studies represent the current status of model capability in simulating such feedbacks with the state-of-the-science treatments.

\subsection{WRF/Chem-MADRID}

WRF/Chem-MADRID has been applied to simulate a 5day episode (12:00 UTC 28 August through 12:00 UTC 2 September of 2000) from the Texas Air Quality Study (TexAQS-2000) in the southern US. The TexAQS-2000 was carried out around the Houston area where exceedance of the National Ambient Air Quality Standard (NAAQS) of $120 \mathrm{ppb}$ $\mathrm{O}_{3}$ occurs most frequently and VOC reactivities are typically much higher than in other urban areas in the US WRF/Chem uses mass (hydrostatic pressure) coordinates. The horizontal grid spacing is $12-\mathrm{km}$ and the vertical resolution is 57 layers from surface to tropopause with vertical intervals varying from $15 \mathrm{~m}$ in the surface layer to $600-680 \mathrm{~m}$ near/at the domain top $(\sim 16 \mathrm{~km})$. The initial conditions, boundary conditions, and emissions are the same ones as the WRF/Chem simulations with MOSAIC described in Fast et al. (2006). Cloud barely occurred during this episode. The cloud microphysical scheme is thus turned off. No aerosol-cloud interaction and aerosol indirect effects were simulated. The simulation results have been evaluated against in situ observations for gas-phase species (e.g., $\mathrm{O}_{3}, \mathrm{SO}_{2}$, nitrogen dioxide $\left(\mathrm{NO}_{2}\right)$, and nitric oxide (NO)), $\mathrm{PM}_{2.5}$, and its composition and remote sensing measurements (e.g., aerosol optical depths) (Zhang et al., 2005c, 2007; Hu et al., 2006).

\section{4hr average $\mathrm{PM}_{2.5}$ on Aug. 29}

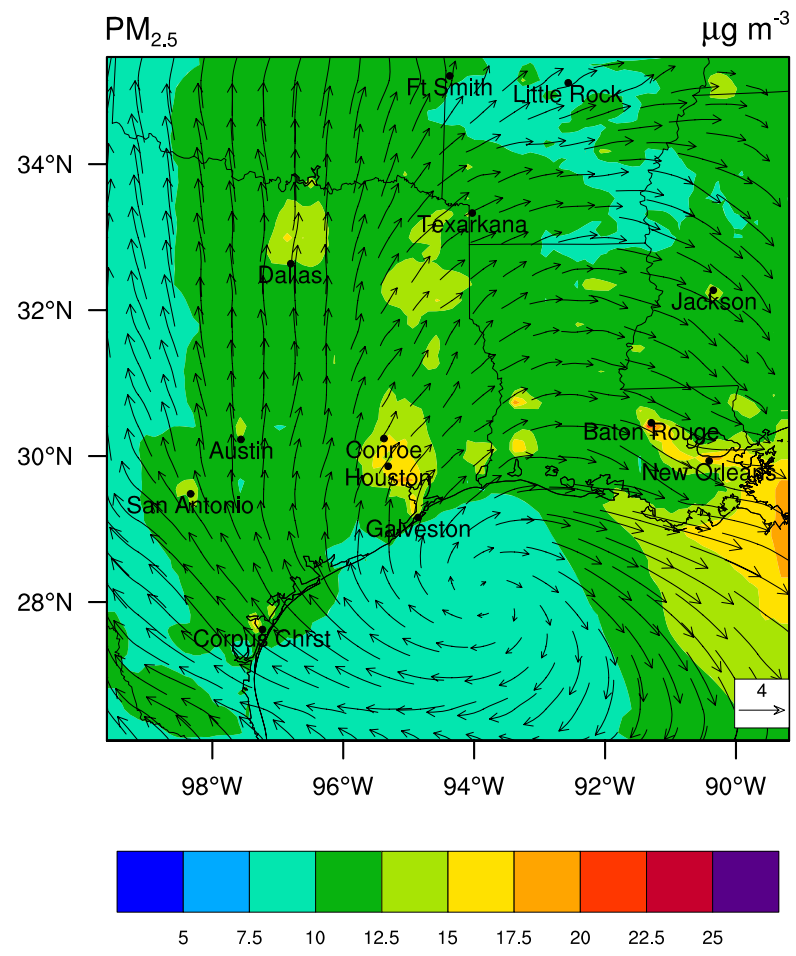

Fig. 2. The spatial distribution of the 24 -h average $P_{2.5}$ concentrations and the 24-h average wind fields predicted by WRF/ChemMADRID on 29 August 2000 (Zhang et al., 2005a).

Figure 2 shows the spatial distribution of the predicted 24$\mathrm{h}$ average $\mathrm{PM}_{2.5}$ concentrations and the 24-h average wind field on 29 August (central daylight time (CDT)), 2000. The predicted $\mathrm{PM}_{2.5}$ distribution is consistent with the patterns of emissions and wind field. The emissions of primary $\mathrm{PM}_{2.5}$ species such as $\mathrm{BC}$ and other unknown inorganic $\mathrm{PM}_{2.5}$ are high in Houston, the emissions of $\mathrm{SO}_{2}$ are high in Baton Rouge and the emissions of $\mathrm{CO}$ and $\mathrm{NO}_{\mathrm{x}}$ are relatively high in Dallas, resulting in relatively high $\mathrm{PM}_{2.5}$ concentrations in those cities and their vicinity. The normalized mean biases (NMBs) of the hourly $\mathrm{O}_{3}$ and $\mathrm{PM}_{2.5}$ predictions are $19.8 \%$ and $41.7 \%$, indicating a moderate overprediction that can be attributed to several factors including overestimation of primary $\mathrm{BC}$ and organic matter (OM) emissions and high aerosol boundary conditions. Figure 3 shows the vertical profiles of $\mathrm{PM}_{2.5}$ concentrations and the differences in vertical temperature $(\mathrm{T})$ and water vapor $\left(\mathrm{Q}_{v}\right)$ mixing ratio between simulations with and without PM at five different times on August 29 at LaPorte that is located in the east of Houston at the coastal area of the Galveston Bay. As shown, $\mathrm{PM}_{2.5}$ concentrations at surface and in the PBL vary significantly from time to time during a day, depending on magnitudes and timing of precursor emissions and related meteorological 

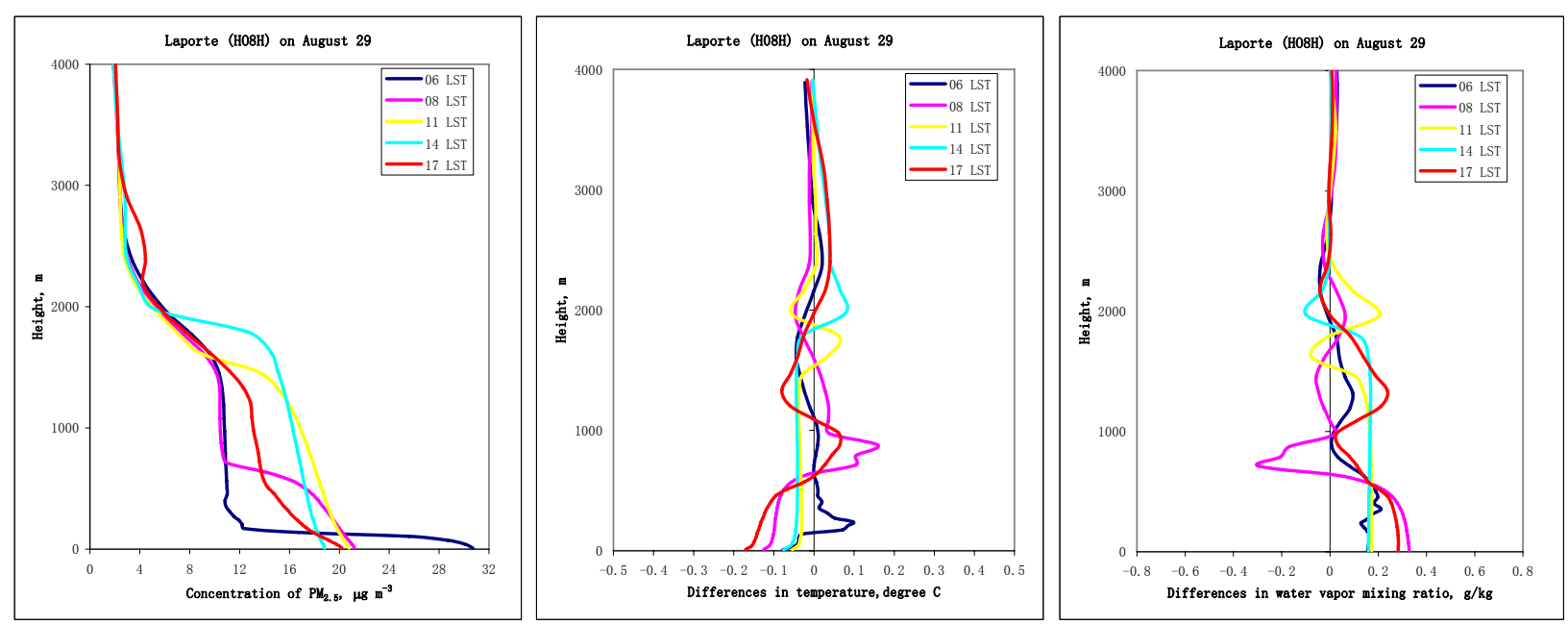

Fig. 3. The vertical distributions of the hourly $\mathrm{PM}_{2.5}$ concentrations and differences in vertical distributions of temperatures and water vapor mixing ratios between simulation with and without aerosols by WRF/Chem-MADRID at La Porte, TX at five times ( 6 a.m., 8 a.m., 11 a.m., 2 p.m., and 5 p.m.) on 29 August 2000 (Zhang et al., 2005c).

conditions such as atmospheric stability, the depth of mixing height, and temperature. The surface $\mathrm{PM}_{2.5}$ reaches the highest at 6 a.m. due to high emissions of primary $\mathrm{PM}_{2.5}$ and precursors of secondary $\mathrm{PM}_{2.5}$ from motor vehicles and relatively-shallow mixing height. The $\mathrm{PM}_{2.5}$ concentration in the PBL reaches the highest at 2 p.m. due likely to the effect of bay breeze. As expected, $\mathrm{T}$ and $\mathrm{Q}_{v}$ respond strongly to changes in $\mathrm{PM}_{2.5}$ concentrations, with maximum changes coincide with maximum gradients in $\mathrm{PM}_{2.5}$ concentrations in the PBL. T reduces by up to $0.18{ }^{\circ} \mathrm{C}$ at/near surface but increases by $0.16{ }^{\circ} \mathrm{C}$ in PBL. Water vapor mixing ratio increases by $3.2 \%$ at/near surface but decreases by $3 \%$ in the PBL. The relatively high $\mathrm{PM}_{2.5}$ concentrations at/near surface reduce net downward solar/thermal-IR radiation, which in turn causes a decrease in $\mathrm{T}$ and an increase in $\mathrm{Q}_{v}$ at/near surface. Opposite changes in the PBL may be caused by radiation absorption of particles and advection of long- or moderately-lived greenhouse gases that absorb thermal-IR radiation emitted by particles aloft.

\subsection{GATOR-GCMOM}

GATOR-GCMOM has been applied to simulate the effect of aerosol feedbacks into regional climate changes over a global domain at a horizontal resolution of $4^{\circ} \mathrm{SN} \times 5^{\circ} \mathrm{WE}$ and two nested domains: a so-called California (CA) Grid at a resolution of $0.2^{\circ} \times 0.15^{\circ}(\sim 21.5 \mathrm{~km} \times 14.0 \mathrm{~km})$ and a socalled the South Coast Air Basin Grid: at a resolution of $0.045^{\circ} \times 0.05^{\circ}(\sim 4.7 \mathrm{~km} \times 5 \mathrm{~km})($ Jacobson et al., 2007). The vertical resolutions are 39 sigma levels up to $0.425 \mathrm{hPa}$ for the global domain and 26 layers up to $103.5 \mathrm{hPa}$, each matching the bottom 26 global layers (with five layers in the bottom $1 \mathrm{~km}$ for all domains). The baseline simulations were con- ducted for two 1-month periods in 1999: February and August. In sensitivity simulations, emissions of anthropogenic aerosol particles and their precursor gases (AAPPG) such as $\mathrm{BC}, \mathrm{OC}$, sulfate, nitrate, fugitive dust, $\mathrm{SO}_{\mathrm{x}}, \mathrm{NO}_{\mathrm{x}}, \mathrm{NH}_{3}$, and reactive organic gases (ROGs) were turned off. Over the LA basin, AAPPG is found to reduce net downward surface total solar irradiance, near-surface temperatures, and surface wind speeds; increase RHs, aerosol and cloud optical depths, cloud fractions, cloud liquid water; and either increase or decrease precipitation depending on location and magnitude of precipitation intensity.

Figure 4 shows the effect of AAPPG on near-surface wind speeds and vertical profiles of wind speeds over California grid simulated by GATOR-GCMOM in February and August 1999. Aerosols decrease surface wind speed but increase boundary-layer wind speed. The decease is driven primarily by two factors: the cooling at the surface due to the reduction in surface solar radiation and the warming in the upper boundary-layer due to the heating caused by the absorbing aerosols. Both factors stabilize the air, reducing turbulence which in turn reduces vertical flux of horizontal momentum, thus slowing transfer of fast winds aloft to the surface (Jacobson et al. 2007). Figure 5 shows the effect of AAPPG on precipitation for the South coast, CA and the CA grids. AAPPG decreases precipitation in the LA basin and the mountains beyond the basin in February. In August, when precipitation is low, most reductions occur offshore and in the foothills of the San Bernardino Mountains. Some precipitation increases are found on the downslope sides of the San Bernardino and San Gabriel Mountains. Those results are consistent with the findings of Givati and Rosenfeld (2004, 2005). 


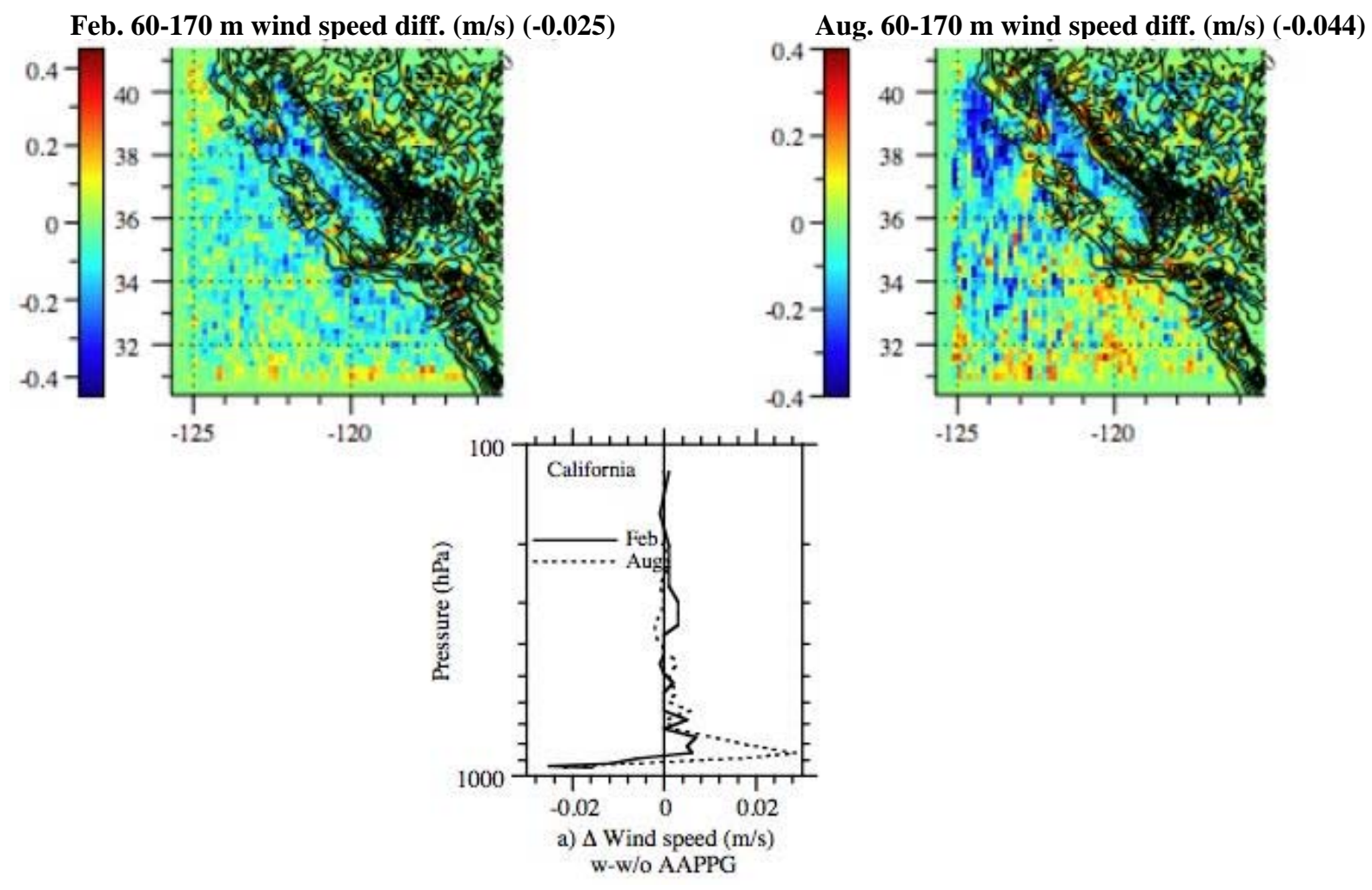

Fig. 4. Differences in the spatial distributions of near-surface wind speeds over California grid and in the domainwide-average vertical distributions of wind speeds between simulation with and without AAPPG by GATOR-GCMOM in February and August 1999. The contours in black lines in the spatial distribution plots indicate topography in meters (provided by M. Z. Jacobson, Stanford University, 2007).

\subsection{CAM3 and MIRAGE2}

3-year global simulations after 4-month spin-up were conducted with CAM3 and MIRAGE2 to understand the differences in simulated aerosol direct and indirect forcing due to different aerosol and cloud microphysical treatments. No nudging was used in those simulations. The horizontal resolution is $4^{\circ}$ latitude $\times 5^{\circ}$ longitude and the vertical resolution is 26 layers from surface to $3.5 \mathrm{hPa}$. Baseline simulations (CAM3_B and MIRAGE2_B) were conducted with default aerosol modules (MOZART4 in CAM3 and PNNL's aerosol module in MIRAGE2, see major differences in Tables 2-6). Four sensitivity simulations were conducted: a CAM3 simulation with constant droplet sedimentation (CAM3_S1), a CAM3 simulation with the same configurations as CAM3_S1 but offline coupling (CAM3_S2), a MIRAGE2 simulation with the same configurations as MIRAGE2 B B but with offline coupling (MIRAGE2_S1), and a CAM3 simulation with the same configurations as CAM3_S2 but with PNNL's aerosol module in replacing MOZART4 (CAM3_S3).

Figure 6 shows results from those simulations. The first aerosol indirect effect (FAIE) from CAM3_B is much larger than that from MIRAGE2_B (3.2 vs. $0.38 \mathrm{~W} \mathrm{~m}^{-2}$ ), the prediction of MIRAGE2_B is much closer to the total aerosol indirect forcing of $0.75 \mathrm{~W} \mathrm{~m}^{-2}$ estimated by IPCC (2007). MIRAGE2 has no droplet sedimentation. Compared with results using bulk sedimentation that is calculated based on mass-weight effective radius of liquid and ice particles, the magnitude of FAIE in CAM3 decreases by $\sim 30 \%$ with a constant sedimentation velocity because sedimentation is reduced. While this result demonstrates the sensitivity of simulated FAIE to droplet sedimentation treatments, neither treatments (i.e., bulk or constant) are realistic because of the use of empirical parameterizations instead of the first principles that treat the sedimentation velocity of particles of individual size. Both online and offline simulations use the same monthly mean aerosol concentrations. But on shorter time scales the online simulation has variability so that less aerosol is present under cloudy conditions, due to enhanced scavenging in clouds. As expected, using an offline aerosol calculation increases magnitude of FAIE in both CAM3 and MIRAGE2 because of increased aerosol presence under cloudy conditions. The use of MIRAGE2 aerosol module in offline CAM3 significantly reduces FAIE in CAM3, suggesting that the addition of an aerosol treatment that allows aerosol size distribution to shift with increasing emissions is likely to produce a smaller indirect effect, particularly when it is interactive (Ghan, 2007). 
Feb. precipitation diff. ( $\mathrm{mm} /$ day) (-0.026)
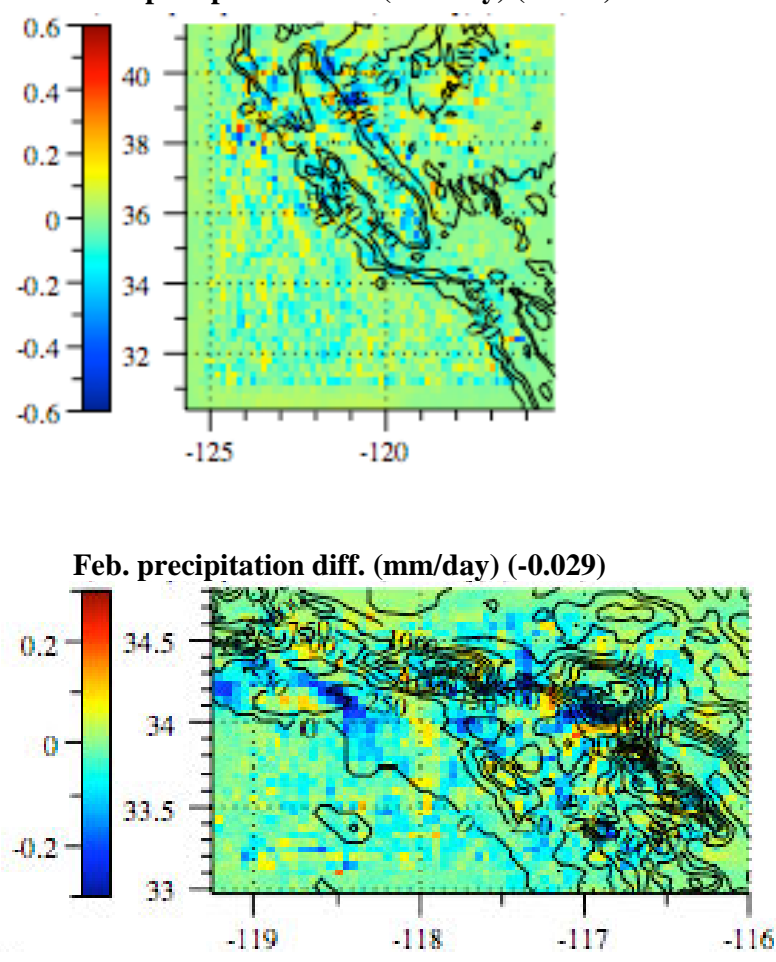
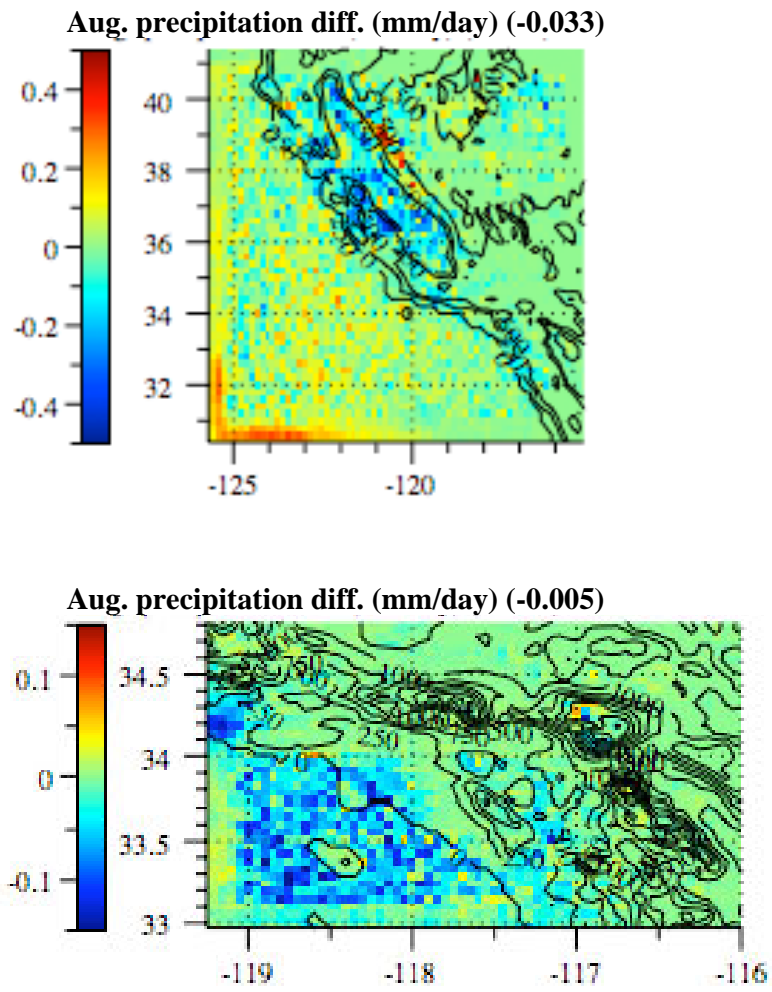

Fig. 5. Differences in the spatial distributions of precipitation over (a) California grid, and (b) the South Coast grids between simulation with and without AAPPG by GATOR-GCMOM in February and August 1999. The contours in black lines indicate topography in meters (provided by M. Z. Jacobson, Stanford University, 2007).

\section{Major challenges and future directions}

Significant progress has been made in the past two decades in the development of online-coupled climate(or meteorology-) chemistry models and their application for simulating global/regional climate, meteorology, and air quality, as well as the entire earth system. However, several major challenges exist for further model development, improvement, and application.

First, accurately representing climate-aerosol-chemistrycloud-radiation feedbacks in 3-D air quality/climate models will remain a major scientific challenge in developing a future generation of online-coupled models for the years to come, as many online-coupled models are currently not significantly- or fully-coupled, in particular, such feedbacks are not fully represented in many online-coupled models. There are several key issues associated with such needs. For example, performing an online calculation of all meteorologically-dependent emissions is necessary in all online-coupled models. There is a critical need for further improvement of model treatments of key processes such as the size-/composition-resolved aerosol/cloud microphysics for multiple size distributions (e.g., new particle formation, SOA, and aerosol/cloud interactions) and aerosol-cloud interactions, as well as subgrid variability associated with these processes. In addition, the scientific understanding of the two-way/chain effects among climate, meteorology, chemistry, aerosol, cloud and radiation will continue to be needed for their accurate representations in online-coupled models. Incomplete and/or inaccurate treatments of model inputs (e.g., emissions) and physics treatments (e.g., aerosol/cloud microphysics and feedbacks) will contribute to the model uncertainties to a large extent.

Second, representing scientific complexity within the computational constraint will continue to be a technical challenge. Key issues include (1) the development of benchmark model and simulation and the use of available measurements to characterize model biases, uncertainties, and sensitivity and to develop bias-correction techniques (e.g., chemical data assimilation); (2) the optimization/parameterization of model algorithms with an acceptable accuracy.

Third, integrated model evaluation and improvement, laboratory/field studies for an improved understanding of major properties/processes will also post significant challenges, as they involve researchers from multiple disciplinaries and require a multidisciplinary and or interdisciplinary approach. Key issues include (1) continuous operation of monitoring networks and remote sensing instrument to provide realtime data (e.g., the AirNow surface monitoring network and Satellite) for data assimilation/model evaluation, (2) 


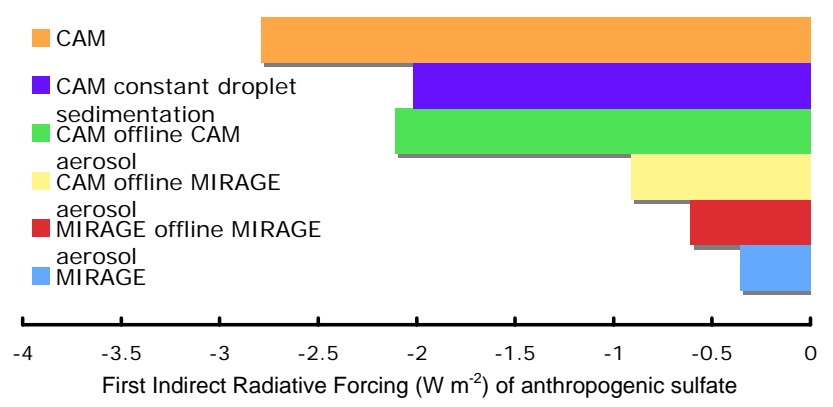

Fig. 6. Global first indirect effect of anthropogenic sulfate simulated by baseline and sensitivity simulations of CAM3 and MIRAGE2 (Ghan, 2007, inclusion with permission of S. J. Ghan, Pacific Northwest National Laboratory, 2007).

the development of process-oriented models to isolate complex feedbacks among various modules/processes in onlinecoupled models, (3) carefully-designed module/model intercomparison to understand mechanistic differences in various modules embedded in online-coupled models and the resultant differences in simulated feedbacks by the 3-D models. Such comparisons should be conducted using both 0-D (i.e., conducting box-model comparisons for different gas-phase chemical mechanisms and aerosol modules that are used in WRF/Chem), 1-D, and 3-D models (e.g., comparing model performance of several online models against observational data for the same episode) when possible.
Fourth, a unified modeling system that allows a single platform to operate over the full scale will represent a substantial advancement in both the science and the computational efficiency. Major challenges include globalization/downscaling with consistent model physics and twoway nesting with mass conservation and consistency. The only such model that exists is GATOR-GCMOM, although other global-through-urban fully-coupled models such as the global-to-urban WRF/Chem (GU-WRF/Chem) are being developed (e.g., O'Connor et al., 2006; Zhang et al., 2008b). Such an unified global-through-urban scale modeling system allows a single platform to operate over the full scale. It represents a substantial advancement in both the science and the computational efficiency, with a new scientific capability for studying important problems that require a consideration of multi-scale feedbacks. For example, locally-emitted air pollutants can affect human health at a neighborhood-scale and air quality and climate at all scales and the changes in climate in turn affect further emissions of biogenic species; locally lifted dust particles can affect local and global circulations, which in turn affects their further lifting.

Finally, integrated earth system modeling for multi-media (e.g., atmosphere, biosphere, ocean, land surface, etc.) will represent models of next generation that can best replicate human's environment. Most current earth system models for atmosphere-land surface-ocean do not include detailed chemistry, aerosol, and cloud treatments and biogeochemical cycles. The integration of such complexities into the earth system models will pose unprecedented challenges for the entire scientific communities. 


\section{Appendix A}

\section{List of Acronyms and Symbols}

\begin{tabular}{|c|c|}
\hline Acronym & Definition \\
\hline 3-D & three-dimensional \\
\hline AAPPG & the anthropogenic aerosol particles and their precursor gases \\
\hline AIM2 & the Aerosol Inorganics Model version 2 \\
\hline APC & the Analytical Predictor of Condensation \\
\hline ASTEEM & the Adaptive Step Time-split Explicit Euler Method \\
\hline ASTEM & the Adaptive Step Time-split Euler Method \\
\hline ARW & the Advanced Research WRF with the Eulerian Mass \\
\hline $\mathrm{BC}$ & black carbon \\
\hline CACM & the California Atmospheric Chemical Mechanism \\
\hline CAM3 (Global) & the Community Atmospheric Model v. 3 \\
\hline CB05 & the 2005 version of Carbon Bond mechanism \\
\hline CBM-EX & The Stanford University's extended Carbon Bond mechanism \\
\hline CBM-Z & the Carbon-Bond Mechanism version Z \\
\hline $\mathrm{CCM}$ & the NCAR Community Climate Model \\
\hline $\mathrm{CCN}$ & cloud condensation nuclei \\
\hline CDT & central daylight time \\
\hline CFCs & chlorofluorocarbons \\
\hline $\mathrm{CH}_{4}$ & methane \\
\hline CMAQ & the EPA's Community Multiple Air Quality \\
\hline CMU & Carnegie Mellon University \\
\hline $\mathrm{CO}$ & carbon monoxide \\
\hline $\mathrm{CO}_{2}$ & carbon dioxide \\
\hline CTMs & chemical transport models \\
\hline DEMA & the iterative dynamic effective medium approximation \\
\hline DMS & dimethyl sulfide \\
\hline EQUISOLV II & the EQUIlibrium SOLVer version 2 \\
\hline EPA & the US Environmental Protection Agency \\
\hline GCM & general circulation model \\
\hline GAQMs & global air quality models \\
\hline GATORG & the Gas, Aerosol, TranspOrt, Radiation, and General circulation model \\
\hline GATOR-GCMOM & the Gas, Aerosol, TranspOrt, Radiation, General Circulation, Mesoscale, Ocean Model \\
\hline \multicolumn{2}{|l|}{$\begin{array}{l}\text { (Global- } \\
\text { through- } \\
\text { urban) }\end{array}$} \\
\hline GATOR/MMTD & the gas, aerosol, transport, and radiation air quality model/a mesoscale meteorological and tracer dispersion model \\
\hline \multicolumn{2}{|r|}{ the gas, a } \\
\hline GChM & the PNNL Global Chemistry Model \\
\hline $\mathrm{H}_{2} \mathrm{O}$ & water \\
\hline $\mathrm{H}_{2} \mathrm{O}_{2}$ & hydrogen peroxide \\
\hline $\mathrm{HO}_{2}$ & hydroperoxy radical \\
\hline $\mathrm{H}_{2} \mathrm{SO}_{3}$ & sulfurous acid \\
\hline $\mathrm{H}_{2} \mathrm{SO}_{4}$ & sulfuric acid \\
\hline IDN & Ice Deposition Nuclei \\
\hline IPCC & Intergovernmental Panel on Climate Change \\
\hline ISORROPIA & "equilibrium" in Greek, refers to The ISORROPIA thermodynamic module \\
\hline LA & Los Angeles \\
\hline MADE/SORGAM & the Modal Aerosol Dynamics Model for Europe (MADE) with the secondary organic aerosol model (SORGAM) \\
\hline MADRID & the Model of Aerosol Dynamics, Reaction, Ionization, and Dissolution \\
\hline MARS-A & the Model for an Aerosol Reacting System (MARS) - version A \\
\hline MCCM & The Multiscale Climate Chemistry Model \\
\hline \multicolumn{2}{|l|}{ (or MM5/Chem) } \\
\hline MESA & the Multicomponent Equilibrium Solver for Aerosols \\
\hline MM5 & the Penn State University (PSU)/NCAR mesoscale model \\
\hline MIRAGE & the Model for Integrated Research on Atmospheric Global Exchanges \\
\hline MOSAIC & the Model for Simulating Aerosol Interactions and Chemistry \\
\hline
\end{tabular}




\begin{tabular}{|c|c|}
\hline Acronym & Definition \\
\hline MOZART4 & the Model for Ozone and Related Chemical Tracers version 4 \\
\hline MSA & methane sulfonic acid \\
\hline MTEM & The Multicomponent Taylor Expansion Method \\
\hline NAAQS & the National Ambient Air Quality Standard \\
\hline NCAR & the National Center for Atmospheric Research \\
\hline NARE & the North Atlantic Regional Experiment \\
\hline $\mathrm{NH}_{4} \mathrm{NO}_{3}$ & ammonium nitrate \\
\hline$\left(\mathrm{NH}_{4}\right)_{2} \mathrm{SO}_{4}$ & ammonium sulfate \\
\hline NMBs & normalized mean biases \\
\hline NMM & the Nonhydrostatic Mesoscale Model \\
\hline $\mathrm{NO}_{3}$ & nitrate radical \\
\hline NO & nitric oxide \\
\hline $\mathrm{NO}_{2}$ & nitrogen dioxide \\
\hline $\mathrm{NO}_{x}$ & nitrogen oxides \\
\hline $\mathrm{N}_{2} \mathrm{O}$ & nitrous oxide \\
\hline NOAA & the National Oceanic and Atmospheric Administration \\
\hline $\mathrm{O}_{3}$ & ozone \\
\hline $\mathrm{OC}$ & organic carbon \\
\hline ODEs & ordinary differential equations \\
\hline $\mathrm{OH}$ & hydroxyl radical \\
\hline $\mathrm{OM}$ & organic matter \\
\hline PAN & peroxyacetyl nitrate \\
\hline PBL & the planetary boundary layer \\
\hline $\mathrm{PM}_{2.5}$ & particles with aerodynamic diameters less than or equal to $2.5 \mu \mathrm{m}$ \\
\hline PNNL & the Pacific Northwest National laboratory \\
\hline $\mathrm{Q}_{v}$ & water vapor \\
\hline RACM & the Regional Atmospheric Chemistry Mechanism \\
\hline RADM2 & the gas-phase chemical mechanism of Regional Acid Deposition Model, version 2 \\
\hline RHs & relative humidities \\
\hline RIs & refractive indices \\
\hline ROGs & reactive organic gases \\
\hline RRTM & the Rapid Radiative Transfer Model \\
\hline $\mathrm{S}(\mathrm{IV})$ & dissolved sulfur compounds with oxidation state IV \\
\hline $\mathrm{SO}_{2}$ & sulfur dioxide \\
\hline SOA & secondary organic aerosol \\
\hline STAR & the US EPA-Science to Achieve Results program \\
\hline $\mathrm{T}$ & temperature \\
\hline TUV & the Tropospheric Ultraviolet and Visible radiation model \\
\hline UCLA-GCM & the University of Los Angeles General Circulation Model \\
\hline VOC & volatile organic compound \\
\hline WRF/Chem & the Weather Research Forecast model with Chemistry \\
\hline ZSR & Zdanovskii-Stokes-Robinson \\
\hline
\end{tabular}

Acknowledgements. The work was supported by the US EPAScience to Achieve Results (STAR) program (Grant \# G6J10504), the US EPA/Office of Air Quality Planning \& Standards via RTI International contract \#4-321-0210288, the NSF Career Award No. Atm-0348819, and the Memorandum of Understanding between the US Environmental Protection Agency (EPA) and the US Department of Commerce's National Oceanic and Atmospheric Administration (NOAA) and under agreement number DW13921548. Thanks are due to S. Ghan and R. Easter at PNNL, M. Jacobson at Stanford University, and A. Baklanov at Danish Meteorological Institute for helpful discussions for MIRAGE/CAM3, GATORGCMOM, and early online models in Russia, respectively. Thanks are also due to (in alphabetical order) A. Baklanov, R. Easter, J. Fast, and W. I. Gustafson Jr, C. J. Jang, B. Langmann, M. Leriche, C. Seigneur, R. Zaveri, and two anonymous referees for their comments online and offline regarding the author's paper published in APCD.

Edited by: H. Wernli 


\section{References}

Abdul-Razzak, H., Ghan, S. J., and Rivera-Carpio, C.: A parameterization of aerosol activation: 1. Single aerosol type, J. Geophys. Res., 103, 6123-6132, 1998.

Abdul-Razzak, H. and Ghan, S. J.: A parameterization of aerosol activation: 2. Multiple aerosol types, J. Geophys. Res., 105, 6837-6844, 2000.

Abdul-Razzak, H. and Ghan, S. J.: A parameterization of aerosol activation: 3. Sectional representation, J. Geophys. Res., 107(D3), doi:10.1029/2001JD000483, 2002.

Ackermann, I. J., Hass, H., Memmesheime, M. R., Ebel, A., Binkowski, F. S., and Shankar,U.: Modal aerosol dynamics model for Europe: Development and first applications, Atmos. Environ., 32(17), 2981-2999, 1998.

Aloyan, A. E., Baklanov, A. A., and Penenko, V. V.: Fictitious regions in numerical simulation of quarry ventilation, Soviet Meteorology and Hydrology, 7, 32-37, 1982.

Aloyan, A. E., Baklanov, A. A., and Penenko, V. V.: Fictitious regions in numerical simulation of quarry ventilation, Soviet Meteorology and Hydrology, 7, 32-37, 1982.

Arakawa, A. and Lamb, V. R.: Computational design of the basic dynamical processes of the UCLA general circulation model, in: Methods in Computational Physics, edited by: Chang, J., Academic Press, New York, 173-265, 1977.

Arakawa, A. and Lamb, V. R.: A potential enstrophy and energy conserving scheme for the shallow water equations, Mon. Weather Rev., 109, 18-36, 1981.

Arteta, J., Cautenet, S., Taghavi, M., and Audiffren, N.: Impact of two chemistry mechanisms fully- coupled with mesoscale model on the atmospheric pollutants distribution, Atmos. Environ., 40, 7983-8001, 2006.

Atwater, M. A.: Thermal changes induced by urbanization and pollutants, J. Appl. Meteorol., 14, 1061-1071, 1975.

Audiffren, N., Buisson, E., Cautenet, S., and Chaumerliac, N.: Photolytic impact of a stratocumulus cloud layer upon the chemistry of an offshore advected plume of pollutants during the NARE 1993 intensive experiment: a numerical study, Atmos. Res., 70, 89-108, 2004.

Austin, J., Butchart, N., and Shine, K. P.: Possibility of an Arctic ozone hole in a doubled- $\mathrm{CO}_{2}$ climate, Nature, 360, 221-225, 1992.

Austin, J. and Butchart, N.: A three-dimensional modeling study of the influence of planetary wave dynamics on polar ozone photochemistry, J. Geophys. Res., 97(D9), 10 165-10 186, doi:10.1029/92JD00505, 1992.

Austin, J., Knight, J., and Butchart, N.: Three-dimensional chemical model simulations of the ozone layer: 1979-2015, Q. J. Roy. Meteor. Soc., 126, 1533-1556, 2000.

Austin, J., Shindell, D., Beagley, S. R., Brühl, C., Dameris, M., Manzini, E., Nagashima, T., Newman, P., Pawson, S., Pitari, G., Rozanov, E., Schnadt, C., and Shepherd, T. G.: Uncertainties and assessments of chemistry-climate models of the stratosphere, Atmos. Chem. Phys., 3, 1-27, 2003, http://www.atmos-chem-phys.net/3/1/2003/.

Baklanov, A.: Numerical Modelling in Mine Aerology, Apatity: USSR Academy of Science, 200 pp. (in Russian), 1988.

Baklanov, A.: Mathematical modelling of the influence of mining on the environment Leeds University Mining Association, edited by: Dowd, P. A., 123-131, 1990.
Baklanov, A., Gross, A., and Sørensen, J. H.: Modelling and forecasting of regional and urban air quality and microclimate, J. Computational Technologies, 9, 82-97, 2004.

Baklanov, A.: Urban air flow researches for air pollution, emergency preparedness and urban weather prediction, chapter 9 in: Flow and transport processes with complex obstructions: Applications to cities, vegetative canopies and Industry, edited by: Gayev, Y. A. and Hunt, J. C. R., NATO Science Series II, Math., Phys. and Chem., 236, Springer, 311-357, 2007.

Baklanov, A., Fay, B., and Kaminski, J.: Overview of existing integrated (off-line and on-line) mesoscale systems in Europe, Report of Working Group 2, April, http://www.cost728.org, 2007a.

Baklanov, A., Hänninen, O., Slørdal, L. H., Kukkonen, J., Bjergene, N., Fay, B., Finardi, S., Hoe, S. C., Jantunen, M., Karppinen, A., Rasmussen, A., Skouloudis, A., Sokhi, R. S., Sørensen, J. H., and Ødegaard, V.: Integrated systems for forecasting urban meteorology, air pollution and population exposure, Atmos. Chem. Phys., 7, 855-874, 2007b,

http://www.atmos-chem-phys.net/7/855/2007/.

Baklanov, A. and U. Korsholm: On-line integrated meteorological and chemical transport modelling: advantages and prospectives, Preprints ITM 2007: the 29th NATA/SPS International Technical Meeting on Air Pollution Modelling and its Application, 2428 September 2007, University of Aveiro, Portugal, 21-34, 2007.

Bao, J.-W., Michelson, S. A., McKeen, S. A., and Grell, G. A.: Meteorological evaluation of a weather-chemistry forecasting model using observations from the TEXAS AQS 2000 field experiment, J. Geophys. Res., 110, D21105, doi:10.1029/2004JD005024, 2005.

Barrie, L. A., Yi, Y., Leaitch, W. R., Lohmann, U., Kasibhatla, P., Roelofs, G.-J., Wilson, J., McGovern, F., Benkovitz, C., Melieres, M. A., Law, K., Prospero, J., Kritz, M., Bergmann, D., Bridgeman, C., Chin, M., Christensen, J., Easter, R., Feichter, J., Jeuken, A., Kjellstrom, E., Koch, D., Land, C., and Rasch, P.: A comparison of large scale atmospheric sulphate aerosol models (COSAM): Overview and highlights, Tellus, 53B, 615-645, 2001.

Barth, M. C., Rasch, P. J., Kiehl, J. T., Benkovitz, C. M., and Schwartz, S. E.: Sulfur chemistry in the National Center for Atmospheric Research Community Climate Model: Description, evaluation, features, and sensitivity to aqueous chemistry, J. Geophys. Res., 105(D1), 1387-1416, doi:10.1029/1999JD900773, 2000.

Bazhin, N. M., Penenko, V. V., Aloyan, A. E., and Skubnevskaya, G. N.: Mathematical modelling of the distribution of atmospheric contaminants taking account of chemical transformations, Russ. Chem. Rev., 60(3), 244-248, 1991.

Beagley, S. R., de Grandpré, J., Koshyk, J. N., McFarlane, N. A., and Shepherd, T. G.: Radiativedynamical climatology of the first-generation Canadian Middle Atmosphere Model, Atmos. Ocean, 35, 293-331, 1997.

Binkowski, F.S. and Shankar, U.: The regional particulate matter model, 1. Model description and preliminary results, J. Geophys. Res., 100, 26 191-26 209, 1995.

Binkowski, F. S. and Roselle, S. J.: Models-3 Community multiscale air quality (CMAQ) model aerosol component, 1. Model description, J. Geophys. Res., 108(D6), 4183, doi:10.1029/2001JD001409, 2003.

Boucher O. and Pham, M.: History of sulfate aerosol 
radiative forcings, Geophys. Res. Lett., 29(9), 1308, doi:10.1029/2001GL014048, 2002.

Boville, B. A., Rasch, P. J., Hack, J. J., and McCaa, J. R.: Representation of Clouds and Precipitation Processes in the Community Atmosphere Model Version 3 (CAM3), J. Climate, 19(11), 2184-2198, 2006.

Braham, R. R. Jr.: An Archaeal Iron-Oxidizing Extreme Acidophile Important in Acid Mine Drainage, Meteorol. Monogr., 18, 141, 1981.

Brasseur, G. P. and Roeckner, E.: Impact of improved air quality on the future evolution of climate, Geophys. Res. Lett., 32, L23704, doi:10.1029/2005GL023902, 2005.

Byun, D. W. and Ching, J. K. S.: Science Algorithms of the EPA Models-3 Community Multiscale Air Quality [CMAQ] Modeling System, EPA/600/R-99/030, Office of Research and Development, U.S. Environmental Protection Agency, Washington, D.C., 1999.

Cariolle, D. and Déqué, M.: Southern hemisphere medium-scale waves and total ozone disturbances in a spectral general circulation model, J. Geophys. Res., 91, 10 825-10 846, 1986.

Cariolle, D., Lasserre-Bigorry, A., Royer, J.-F., and Geleyn, J.-F.: A general circulation model simulation of the springtime Antarctic ozone decrease and its impact on mid-latitudes, J. Geophys. Res., 95(D2), 1883-1898, doi:10.1029/89JD01644, 1990.

Cerveny R. S. and Bailing Jr., R. C.: Weekly cycles of air pollutants, precipitation and tropical cyclones in the coastal NW Atlantic region, Nature, 394, 561-563, 1998.

Cess, R. D., Potter, G. L., Blanchet, J. P., Boer, G. J., Ghan, S. J., Kiehl, J. T., Le Treut, H., Li, Z.-X., Liang, X.-Z., Mitchell, J. F. B., Morcrette, J.-J., Randall, D. A., Riches, M. R., Roeckner, E., Schlese, U., Slingo, A., Taylor, K. E., Washington, W. M., Wetherald, R. T., and Yagai, I.: Interpretation of Cloud-Climate Feedback as Produced by 14 Atmospheric General Circulation Models, Science, 245(4917), 513-516, 1989.

Cess, R. D., Potter, G. L., Ghan, S.J., and Gates, W. L.: The climatic effects of large injections of atmospheric smoke and dust: A study of climate feedback mechanisms with one- and threedimensional models, J. Geophys. Res., 90, 12 937-12 950, 1985.

Chang, J. S., Binkowski, F. S., Seaman, N. L., McHenry, J. N., Samson, P. J., Stockwell, W. R., Walcek, C. J., Madronich, S., Middleton, P. B., Pleim, J. E., and Lansford, H. H.: The regional acid deposition model and engineering model. State-ofScience/Technology, Report 4, National Acid Precipitation Assessment Program, Washington, DC, 1989.

Chen, S.-H., and Sun, W.-Y.: A one-dimensional time dependent cloud model, J. Meteor. Soc. Japan, 80, 99-118, 2002.

Chenevez, J., Baklanov, A., and Sørensen, J. H.: Pollutant transport schemes integrated in a numerical weather prediction model: Model description and verification results, Meteorol. Appl., 11(3), 265-275, 2004

Chou, C., Neelin, J. D., Tu, J.-Y. and Chen, C.-T.: Regional tropical precipitation change mechanisms in ECHAM4/OPYC3 under global warming, J. Climate, 19, 4207-4223, 2006.

Chou, M. D. and Suarez, M. J.: An efficient thermal infrared radiation parameterization for use in general circulation models, NASA Tech. Memo., 104606, 3, 85 pp., 1994.

Chuang, C. C., Penner, J. E., Taylor, K. E., Grossman, A. S., and Walton, J. J.: An assessment of the radiative effects of anthropogenic sulfate, J. Geophys. Res., 102, 3761-3778, 1997.
Chuang, C. C., Penner, J. E., Prospero, J. M., Grant, K. E., Rau, G. H., and Kawamoto, K.: Cloud susceptibility and the first aerosol indirect forcing: Sensitivity to black carbon and aerosol concentrations, J. Geophys. Res., 107(D21), 4564, doi:10.1029/2000JD000215, 2002.

Chung, S. H. and Seinfeld, J. H.: Global distribution and climate forcing of carbonaceous aerosols, J. Geophys. Res., 107(D19), 4407, doi:10.1029/2001JD001397, 2002.

Chung, S. H. and Seinfeld, J. H.: Climate response of direct radiative forcing of anthropogenic black carbon, J. Geophys. Res., 110(D1), 1102, doi:10.1029/2004JD005441, 2005.

Clark, J. H. E.: A quasi-geostrophic model of the winter stratospheric circulation, Mon. Weather Rev., 98(6), 443-461, 1970.

Cunnold, D., Alyea, F., Phillips, N., and Prinn, R.: A threedimensional dynamical-chemical model of atmospheric ozone, J. Atmos. Sci., 32, 170-194, 1975.

Collins, W. D. Rasch, P. J., Boville, B. A., Hack, J. J., McCaa, J. R., Williamson, D. L., Kiehl, J. T., and Briegleb, B.: Description of the NCAR Community Atmosphere Model (CAM3), Tech. Rep. NCAR/TN-464_STR, National Center for Atmospheric Research, Boulder, CO, 226 pp., 2004.

Collins, W. D., Rasch, P. J., Boville, B. A., Hack, J. J., McCaa, J. R., Williamson, D. L., and Briegleb, B. P.: The Formulation and Atmospheric Simulation of the Community Atmosphere Model, Version 3 (CAM3), J. Climate, 19, 2144-2161, 2006 a.

Collins, W. D., Bitz, C. M., Blackmon, M. L., Bonan, G. B., Bretherton, C. S., Carton, J. A., Chang, P., Doney, S. C., Hack, J. J., Henderson, T. B., Kiehl, J. T., Large, W. G., McKenna, D. S., Santer, B. D., and Smith, R. D.: The Community Climate System Model version 3 (CCSM3), J. Climate, 19, 2122-2143, $2006 \mathrm{~b}$.

Covey, C., Schneider, S. H., and Thompson, S. L.: Global atmospheric effects of massive smoke injections from a nuclear war: results from general circulation model simulations, Nature, 308 , 21-25, 1984.

Cox, P. M.: Description of the TRIFFID dynamic global vegetation model, Tech. Note 24, Hadley Centre, Met Office, 16 pp., 2001.

Côté, J., Gravel, S., Méthot, A., Patoine, A., Roch, M., and Staniforth, A.: The operational CMC MRB Global Environmental Multiscale (GEM) model: Part I - Design considerations and formulation, Mon. Weather Rev., 126, 1373-1395, 1998a.

de Laat, A. T. J., Zachariasse, M., Roelofs, G. J., van Velthoven, P., Dickerson, R. R., Rohoads, K. P., Oltmans, S. J., and Lelieveld, J.: Tropospheric $\mathrm{O}_{3}$ distribution over the Indian Ocean during spring 1995 evaluated with a chemistry-climate model, J. Geophys. Res., 104(D11), 13, 881-13 893, 1999.

Dameris, M., Grewe, V., Hein, R., and Schnadt, C.: Assessment of future development of the ozone layer, Geophys. Res. Lett., 25 , 3579-3582, 1998

Dameris, M., Grewe, V., Ponater, M., Deckert, R., Eyring, V., Mager, F., Matthes, S., Schnadt, C., Stenke, A., Steil, B., Brühl, C., and Giorgetta, M. A. : Long-term changes and variability in a transient simulation with a chemistry-climate model employing realistic forcings, Atmos. Chem. Phys., 5, 2121-2145, 2005, http://www.atmos-chem-phys.net/5/2121/2005/.

Del Genio, A. D., Yao, M.-S., Kovari, W., and Lo, K. K.-W.: A prognostic cloud water parameterization for global climate models, J. Climate, 9, 270-304, 1996.

Derwent, R. G., Collins, W. J., Jenkin, M. E., Johnson, C. E., and Stevenson, D. S.: The global distribution of secondary partic- 
ulate matter in a 3-D Lagrangian chemistry transport model, J. Atmos. Chem., 44, 57-95, 2003.

Doney, S. C., Lindsay, K., Fung, I., and John, J.: Natural variability in a stable, 1000-yr global coupled climate-carbon cycle simulation, J. Climate, 19, 3033-3054, 2006.

Dudia, J.: Numerical study of convection observed during the winter monsoon experiment using a mesoscale two-dimensional model, J. Atmos. Sci., 46, 3077-3107, 1989.

Eagen, R. C., Hobbs, P. V., and Radke, L. F.: Particle emissions from a large Kraft paper mill and their effects on the microstructure of warm clouds, J. Appl. Meteor., 13, 535-552, 1974.

Easter, R. C., Ghan, S. J., Zhang, Y., Saylor, R. D., Chapman, E. G., Laulainen, N. S., Abdul-Razzak, H., Leung, L. R., Bian, X., and Zaveri, R. A.: MIRAGE: Model description and evaluation of aerosols and trace gases, J. Geophys. Res., 109(D2), 0210, doi:10.1029/2004JD004571, 2004.

Eckman, R. S., Grose, W. L., Turner, R. E., and Blackshear, W. T.: Polar ozone depletion: A three-dimensional chemical modeling study of its long-term global impact, J. Geophys. Res., 101(D17), 22 977-22 990, doi:10.1029/96JD02130, 1996.

Eder, B. K., Kang, D., Stein, A. F., Grell, G. A., Peckham, S. E., and McHenry, J.: The New England Air Quality Forecasting Pilot Program: Development of an Evaluation Protocol and Performance Benchmark, J. Air and Waste Manag., 55, 20-27, 2005.

Eyring, V., Harris, N. R. P., Rex, M., Shepherd, T. G., Fahey, D. W., Amanatidis, G. T., Austin, J., Chipperfield, M. P., Dameris, M., De F. Forster, P. M., Gettelman, A., Graf, H. F., Nagashima, T., Newman, P. A., Pawson, S., Prather, M. J., Pyle, J. A., Salawitch, R. J., Santer, B. D., and Waugh, D. W.: A strategy for processoriented validation of coupled chemistry-climate models, B. Am. Meteorol. Soc., 86(8), 1117-1133, doi:10.1175/BAMS868-1117, 2005.

Fast, J. D.: Evaluation of the boundary layer characteristics and pollutants in Mexico City predicted by WRF: Presented at the 6th Annual WRF/15th Annual MM5 Users' Workshop, Boulder, $\mathrm{CO}, 2005$

Fast, J. D., Gustafson Jr., W. I., Easter, R. C., Zaveri, R. A., Barnard, J. C., Chapman, E. G., and Grell, G. A.: Evolution of ozone, particulates, and aerosol direct forcing in an urban area using a new fully-coupled meteorology, chemistry, and aerosol model, J. Geophys. Res., 111, D21305, doi:10.1029/2005JD006721, 2006.

Feichter, J., Kjellstrom, E., Rodhe, H., Dentener, F., Lelieveld, J., and Roelofs, G.-J.: Simulation of the tropospheric sulfur cycle in a global climate model, Atmos. Environ., 30, 1693-1707, 1996.

Feichter, J., Lohmann, U., and Schult, I.: The atmospheric sulfur cycle in ECHAM-4 and its impact on the shortwave radiation, Clim. Dynam., 13, 235-246, 1997.

Feichter J., Sausen, R., Graß1, H., and Fiebig, M.: Comment on "Control of fossil-fuel particulate black carbon and organic matter, possibly the most effective method of slowing global warming”, by Jacobson, M. Z., J. Geophys. Res., 108(D24), 4767, doi:10.1029/2002JD003223, 2003.

Friedlingstein, P., Cox, P., Betts, R., Bopp, L., von Bloh, W., Brovkin, V., Cadule, P., Doney, S., Eby, M., Fung, I., Bala, B., John, J., Jones, C., Joos, F., Kato, T., Kawamiya, M., Knorr, W., Lindsay, K., Matthews, H. D., Raddatz, T., Rayner, P., Reick, C., Roeckner, E., Schnitzler, K.-G., Schnurr, R., Strassmann, K., Weaver, A. J., Yoshikawa, C., and Zeng, N.: Climate-Carbon Cycle Feedback Analysis: Results from the C4MIP Model Inter- comparison, J. Climate, 19, 3337-3353, 2006.

Frost G. J., McKeen, S. A., Trainer, M., Ryerson, T. B., Neuman, J. A., Roberts, J. M., Swanson, A., Holloway, J. S., Sueper, D. T., Fortin, T., Parrish, D. D., Fehsenfeld, F. C., Flocke,F., Peckham, S. E., Grell, G. A., Kowal, D., Cartwright, J., Auerbach, N., and Habermann, T.: Effects of changing power plant $\mathrm{NO}_{x}$ emissions on ozone in the eastern United States: Proof of concept, J. Geophys. Res., 111, D12306, doi:10.1029/2005JD006354, 2006.

Gery, M. W., Whitten, G. Z., Killus, J. P., and Dodge, M. C.: A photochemical kinetics mechanism for urban and regional scale computer modeling, J. Geophys. Res., 94, 12 925-12 956, 1989.

Ghan, S. J.: Sensitivity of Indirect Effect to Aerosol Treatment, presentation at the 12th Annual CCSM Workshop, 19-21 June, Breckenridge, CO., 2007.

Ghan, S., and Easter, R.: Impact of cloud-borne aerosol representation on aerosol direct and indirect effects, Atm. Chem. Phys., 6, 4163-4174, 2006.

Ghan, S. J., Laulainen, N. S., Easter, R. C., Wagener, R., Nemesure, S., Chapman, E. G., Zhang, Y., and Leung, L. R.: Evaluation of aerosol direct radiative forcing in MIRAGE, J. Geophys. Res., 106, 5295-5316, 2001a.

Ghan, S. J., MacCracken, M. C., and Walton, J. J.: Climatic response to large atmospheric smoke injections: sensitivity studies with a tropospheric general circulation model, J. Geophys. Res., 106, 5295-5316, 1988.

Ghan, S. J., Leung, L. R., Easter, R. C., and Abdul-Razzak, H.: Prediction of cloud droplet number in a general circulation model, J. Geophys. Res., 102(D18), 21 777-21 794, doi:10.1029/97JD01810, 1997a.

Ghan, S. J., Ruby Leung, L., and Hu, Q.: Application of cloud microphysics to NCAR community climate model, J. Geophys. Res., 102(D14), 16 507-16528, doi:10.1029/97JD00703, 1997b.

Ghan, S. J., Ruby Leung, L., and Hu, Q.: Application of cloud microphysics to NCAR community climate model, J. Geophys. Res., 102(D14), 16507-16528, doi:10.1029/97JD00703, 1997 b.

Ghan, S. J., Easter, R. C., Hudson, J., and Breon, F.-M.: Evaluation of aerosol indirect radiative forcing in MIRAGE, J. Geophys. Res., 106, 5317-5334, $2001 \mathrm{~b}$.

Ghan, S. J., Easter, R. C., Chapman, E. G., Abdul-Razzak, H., Zhang, Y., Leung, L. R., Laulainen, N. S., Saylor, R. D., and Zaveri, R. A.: A physically-based estimate of radiative forcing by anthropogenic sulfate aerosol, J. Geophys. Res., 106, 52795293, 2001c.

Ghan, S. J. and Schwartz, S. E.: Aerosol properties and processes, a path from field and laboratory measurements to global climate models, B. Am. Meteorol. Soc., 88(7), 1059-1083, 2007.

Giorgi, F. and Shields, C.: Tests of precipitation parameterizations available in the latest version of the NCAR regional climate model (RegCM) over continental U.S., J. Geophys. Res., 104, 6353-6375, 1999.

Giorgi, F., Marinucci, M. R., and Bates, G. T.: Development of a second generation regional climate model(RegCM2), I, Boundary-layer and radiative transfer processes, Mon. Weather Rev., 121, 2794-2813, 1993a.

Giorgi, F., Marinucci, M. R., Bates, G. T., and De Canio, G.: Development of a second generation regional climate model(RegCM2), II, Convective processes and assimilation of lateral boundary conditions, Mon. Weather Rev., 121, 28142832, 1993 b. 
Giorgi, F., Bi, X., and Qian, Y.,: Direct radiative forcing and regional climatic effects of anthropogenic aerosols over East Asia: A regional coupled climate-chemistry/aerosol model study, J. Geophys. Res., 107(D20), 4439, doi:10.1029/2001JD001066, 2002.

Givati, A. and Rosenfeld, D.: Quantifying Precipitation Suppression due to air pollution, J. Appl. Meteor., 43, 1038-1056, 2004.

Givati, A. and Rosenfeld, D.: Separation between Cloud-Seeding and Air-Pollution Effects, J. Appl. Meteor., 44, 1298-1314, 2005.

Gong, S. L., Barrie, L. A., and Lazare, M.: Canadian Aerosol Module (CAM): A size-segregated simulation of atmospheric aerosol processes for climate and air quality models, 2. Global seasalt aerosol and its budgets, J. Geophys. Res., 107(D24), 4779, doi:10.1029/2001JD002004, 2002.

Gong, S. L., Barrie, L. A., Blanchet, J.-P., von Salzen, K., Lohmann, U., Lesins, G., Spacek, L., Zhang, L. M., Girard, E., Lin, H., Leaitch, R., Leighton, H., Chylek, P., and Huang, P.: Canadian Aerosol Module: A size-segregated simulation of atmospheric aerosol processes for climate and air quality models: 1. Model development, J. Geophys. Res., 108(D1), 4007, doi:10.1029/2001JD002002, 2003.

Gordon, C., Cooper, C., Senior, C. A., Banks, H., Gregory, J. M., Johns, T. C., Mitchell, J. F. B., and Wood, R. A.: The simulation of SST, sea ice extents and ocean heat transports in a version of the Hadley Centre coupled model without flux adjustments, Clim. Dynam., 16, 147-168, 2000.

Gustafson, W. I., Chapman, E. G., Ghan, S. J., Easter, R. C., and Fast, J. D.: Impact on modeled cloud characteristics due to simplified treatment of uniform cloud condensation nuclei during NEAQS 2004, Geophys. Res. Lett., 34, L19809, doi:10.1029/2007GL0300321, 2007.

Granier, C. and Brasseur, G.: Ozone and other trace gases in the Arctic and Antarctic regions: Three-dimensional model simulations, J. Geophys. Res., 96(D2), 2995-3011, doi:10.1029/90JD01779, 1991.

Grell, G. A., Dudhia, J., and Stauffer, D.: A description of the fifthgeneration Penn State/NCAR Mesocale Model (MM5), NCAR Technical Note, TN-398+STR, National Center for Atmospheric Research, Boulder, CO, 138 pp., 1994.

Grell, G. A., Emeis, S., Stockwell, W. R., Schoenemeyer, T., Forkel, R., Michalakes, J., Knoche, R., and Seidl, W.: Application of a multiscale, coupled MM5/chemistry model to the complex terrain of the VOTALP valley campaign, Atmos. Environ. 34, 14351453,2000

Grell, G. A., McKeen, S., Michalakes, J., Bao, J.-W., Trainer, M., and Hsie, E.-Y.: Real-time simultaneous prediction of air pollution and weather during the Houston 2000 Field Experiment, presented at the 4th Conference on Atmospheric Chemistry: Atmospheric Chemistry and Texas Field Study, 13-17 January, American Meteorological Society, Orlando, 2002.

Grell, G. A., Peckham, S. E., Schmitz, R., McKeen, S. A., Frost, G., Skamarock, W. C., and Eder, B.: Fully coupled "online" chemistry within the WRF model, Atmos. Environ., 39, 6957-6975, 2005.

Grenfell, J. L., Shindell, D. T., Koch, D., and Rind, D.: Chemistryclimate interactions in the Goddard Institute for Space Studies general circulation model 2, New insights into modeling the preindustrial atmosphere, J. Geophys. Res., 106(D24), 33 435-
33 452, doi:10.1029/2000JD000090, 2001.

Griffin, R. J., Cocker III, D. R., Flagan, R. C., and Seinfeld, J. H.: Organic aerosol formation from the oxidation of biogenic hydrocarbons, J. Geophys. Res., 104, 3555-3567, 1999.

Griffin, R. J., Dabdub, D., Kleeman, M. J., Fraser, M. P., Cass, G. R., and Seinfeld, J. H.: Secondary Organic Aerosol: III. Urban/Regional Scale Model Of Size- And Composition-Resolved Aerosols, J. Geophys. Res., 107(D17), 4334, doi:10.1029/2001JD000544, 2002.

Guenther A., Karl, T., Harley, P., Wiedinmyer, C., Palmer, P. I., and Geron, C.: Estimates of global terrestrial isoprene emissions using MEGAN (Model of Emissions of Gases and Aerosols from Nature), Atmos. Chem. Phys., 6, 107-173, 2006, http://www.atmos-chem-phys.net/6/107/2006/.

Hack, J. J., Boville, B. A., Briegleb, B. P., Kiehl, J. T., Rasch, P. J., and Williamson, D. L.: Description of the NCAR Community Climate Model (CCM2), Tech. Rep. NCAR/TN382_STR, National Center for Atmospheric Research, 120 pp., 1993.

Hack, J. J., Caron, J. M., Yeager, S. G., Oleson, K. W., Holland, M. M., Truesdale, J. E., and Rasch, P. J.: Simulation of the global hydrological cycle in the CCSM Community Atmosphere Model version 3 (CAM3): Mean features, J. Climate, 19, 2199-2221, 2006.

Harrington, D. Y. and Kreidenweis, S. M.: Simulation of Sulfate Aerosol Dynamics, I. Model Description, Atmos. Environ., 32, 1691-1700, 1998.

Hauglustaine, D. A., Hourdin, F., Jourdain, L., Filiberti, M.-A., Walters, S., Lamarque, J.-F., and Holland, E. A.: Interactive chemistry in the Laboratoire de Météorologie Dynamique general circulation model: Description and background tropospheric chemistry evaluation, J. Geophys. Res., 109, D04314, doi:10.1029/2003JD003957, 2004.

Heald, C. L.: Update on CAM/CLM Biogenic VOC Emissions and Secondary Organic Aerosols, presentation at the Chemistry-Climate Working Group Meeting, CCSM, February, 2007.Henze, D.K. and J.H. Seinfeld: Global secondary organic aerosol formation from isoprene oxidation, Geophys. Res. Lett., 33, L09812, doi:1029/2006GL025976, 2006.

Hogrefe, C., Lynn, B., Civerolo, K., Ku, J.-Y., Rosenthal, J., Rosenzweig, C., Goldberg, R., Gaffin, S., Knowlton, K., and Kinney, P. L.: Simulating changes in regional air pollution over the eastern United States due to changes in global and regional climate and emissions, J. Geophys. Res., 109(D2), 2301, doi:10.1029/2004JD004690, 2004.

Hong, S.-Y., Lim, K.-S., Kim, J.-H., Lim,J.-O. J., and Dudhia, J.: WRF Single-Moment 6-Class Microphysics Scheme (WSM6), presented at the 7th Annual WRF Users Workshop, 19-22 June, Boulder, CO, 2006.

Hu, X.-M. and Zhang, Y.: Implementation and testing of a new aerosol module in WRF/Chem, presentation at the 86th AMS Annual Meeting/the 8th Conference on atmospheric chemistry, Atlanta, GA, 27 January-3 February, 2006.

Hu, X.-M. and Zhang, Y.: Gas/Particle Mass Transfer Treatments in WRF/Chem-MADRID: Development, Application, and Evaluation, presentation at the 8th Annual WRF User's Workshop, 11-15 June, Boulder, CO., 2007.

Hu, X.-M., Frazier, E. F., Zhang, Y., McKeen, S. A., Grell, G. A., Peckham, S. E., Yu, S.-C., and Schere, K. L.: Evaluation of WRF/Chem-MADRID with the July 2004 New England Air 
Quality Study Episode, to be presented at the 6th Annual CMAS Models-3 User's Conference, 1-3 October 2007, Chapel Hill, NC., 2007.

Hu, X.-M., Zhang, Y., Jacobson, M. Z., and Chan, C. K.: Coupling and Evaluating Gas/Particle Mass Transfer Treatments for Aerosol Simulation and Forecast, J. Geophys. Res., in press, 2008.

Huang, J.-P., Hu, X.-M., Zhang, Y., Sarwar, G., Otte, T. L., Gilliam, R., and Schere, K. L.: Implementation and Testing of the 2005 Version of Carbon Bond Mechanism in WRF-chem, presentation at the 7th Annual WRF User's Workshop, Boulder, CO, 1922 June, 2006.

Hunt, B. G.: Experiments with a stratospheric general circulation model III. Large-scale diffusion of ozone including photochemistry, Mon. Weather Rev., 97(4), 287-306, 1969.

Hurrell, J. W., Hack, J. J., Phillips, A., Caron, J., and Yin, J.: The dynamical simulation of the Community Atmospheric Model Version 3 (CAM3), J. Climate, 19, 2162-2183, 2006.

Intergovernmental Panel on Climate Change (IPCC): Climate Change 2001, The Scientific Basis, Contribution of Working Group I to the Third Assessment Report of the Ingovernmental Panel on Climate Change, edited by: Houghton, J. T., Ding, Y., Griggs, D. J., Noguer, M., van der Linden, P. J., Dai, X., Maskell, K., and Johnson, C. A., 944 pp., Cambridge Univ. Press, New York, 2001.

Intergovernmental Panel on Climate Change (IPCC): Climate Change 2007, http://www.ipcc.ch/, 2007.

Iversen, T. and Seland, Ø.: A scheme for process-tagged $\mathrm{SO}_{4}$ and $\mathrm{BC}$ aerosols in NCAR CCM3: Validation and sensitivity to cloud processes, J. Geophys. Res., 107(D24), 4751, doi:10.1029/2001JD000885, 2002.

Jacobson, M. Z.: Developing, coupling, and applying a gas, aerosol, transport, and radiation model to study urban and regional air pollution, Ph. D. Thesis, Department of Atmospheric Sciences, University of California, Los Angeles, 436 pp., 1994.

Jacobson, M. Z.: Simulations of the rates of regeneration of the global ozone layer upon reduction or removal of ozonedestroying compounds, EOS Supplement, Fall, 1995, p. F119. "Closing the hole," Geotimes Magazine (American Geological Institute), April 1996, 9, 1995.

Jacobson, M. Z., Lu, R., Turco, R. P., and Toon, O. B.: Development and application of a new air pollution modeling system. Part I: Gas-phase simulations, Atmos. Environ., 30B, 1939-1963, 1996.

Jacobson, M. Z.: Development and application of a new air pollution modeling system - II. Aerosol module structure and design, Atmos. Environ., 31, 131-144, 1997a.

Jacobson, M. Z.: Development and application of a new air pollution modeling system, Part III: Aerosol-phase simulations, Atmos. Environ., 31A, 587-608, 1997b.

Jacobson, M. Z.: Testing the impact of interactively coupling a meteorological model to an air quality model, in: Measurements and Modeling in Environmental Pollution, edited by: San Jose, R. and Brebbia, C. A., Computational Mechanics Publications, Southampton, 241-249, 1997c.

Jacobson, M. Z.: Studying the effects of aerosols on vertical photolysis rate coefficient and temperature profiles over an urban airshed, J. Geophys. Res., 103, 10 593-10 604, 1998.

Jacobson, M. Z.: Isolating nitrated and aromatic aerosols and nitrated aromatic gases as sources of ultraviolet light absorption, J.
Geophys. Res., 104, 3527-3542, 1999a.

Jacobson, M. Z.: Studying the effects of soil moisture on ozone, temperatures, and winds in Los Angeles, J. Appl. Meteorol., 38, 607-616, 1999b.

Jacobson, M. Z.: Studying the effects of calcium and magnesium on size-distributed nitrate and ammonium with EQUISOLV II, Atmos. Environ., 33, 3635-3649, 1999c.

Jacobson, M. Z.: A physically-based treatment of elemental carbon optics: Implications for global direct forcing of aerosols, Geophys. Res. Lett., 27, 217-220, 2000.

Jacobson, M. Z.: Strong radiative heating due to the mixing state of black carbon in atmospheric aerosols, Nature, 409, 695-697, 2001a.

Jacobson, M. Z.: Global direct radiative forcing due to multicomponent anthropogenic and natural aerosols, J. Geophys. Res., 106, 1551-1568, 2001b.

Jacobson, M. Z.: GATOR-GCMM: A global- through urban-scale air pollution and weather forecast model 1. Model design and treatment of subgrid soil, vegetation, roads, rooftops, water, sea, ice, and snow, J. Geophys. Res., 106, 5385-5401, 2001c.

Jacobson, M. Z.: GATOR-GCMM: 2. A study of day- and nighttime ozone layers aloft, ozone in national parks, and weather during the SARMAP Field Campaign, J. Geophys. Res., 106, 5403-5420, 2001d.

Jacobson, M. Z.: Control of fossil-fuel particulate black carbon plus organic matter, possibly the most effective method of slowing global warming, J. Geophys. Res., 107(D19), 4410, doi:10.1029/2001JD001376, 2002.

Jacobson, M. Z.: Reply to comment by: J. Feichter et al. on Control of fossil-fuel particulate black carbon and organic matter, possibly the most effective method of slowing global warming, J. Geophys. Res., 108(D24), 4768, doi:10.1029/2002JD003299, 2003a.

Jacobson, M. Z.: Reply to comment by: J. E. Penner on Control of fossil\&hyphen;fuel particulate black carbon and organic matter, possibly the most effective method of slowing global warming, J. Geophys. Res., 108(D24), 4772, doi:10.1029/2003JD003403, 2003b.

Jacobson, M. Z.: Development of mixed-phase clouds from multiple aerosol size distributions and the effect of the clouds on aerosol removal, J. Geophys. Res., 108(D8), 4245, doi:10.1029/2002JD002691, 2003c.

Jacobson, M. Z.: The short-term cooling but long-term global warming due to biomass burning, J. Climate, 17, 2909-2926, $2004 a$.

Jacobson, M. Z.: The climate response of fossil-fuel and biofuel soot, accounting for soot's feedback to snow and sea ice albedo and emissivity, J. Geophys. Res., 109, D21201, doi:10.1029/2004JD004945, 2004b.

Jacobson, M. Z. and Seinfeld, J. H.: Evolution of nanoparticle size and mixing state near the point of emission, Atmos. Environ., 38, 1839-1850, 2004.

Jacobson, M. Z., Seinfeld, J. H., Carmichael, G. R., and Streets, D. G.: The effect on photochemical smog of converting the U.S. fleet of gasoline vehicles to modern diesel vehicles, Geophys. Res. Lett., 31, L02116, doi:10.1029/2003GL018448, 2004.

Jacobson, M. Z.: A solution to the problem of nonequilibrium acid/base gas-particle transfer at long time step, Aerosol Sci. Technol., 39, 92-103, 2005a. 
Jacobson, M. Z.: Studying ocean acidification with conservative, stable numerical schemes for nonequilibrium air-ocean exchange and ocean equilibrium chemistry, J. Geophys. Res., 110, D07302, doi:10.1029/2004JD005220, 2005b.

Jacobson, M. Z.: Effects of absorption by soot inclusions within clouds and precipitation on global climate, J. Phys. Chem., 110, 6860-6873, 2006a.

Jacobson, M. Z.: Comment on "Fully coupled "online" chemistry within the WRF model," by Grell et al., Atmos. Environ., 39, 6957-6975, 2006b.

Jacobson, M. Z.: Effects of ethanol (E85) versus gasoline vehicles on cancer and mortality in the United States, Environ. Sci. Technol., 41(11), 4150-4157, doi:10.1021/es062085v, 2007.

Jacobson, M. Z. and Kaufmann, Y. J.: Aerosol reduction of the wind, Geophys. Res. Lett., 33, L24814, doi:10.1029/2006GL027838, 2006.

Jacobson, M. Z., Kaufmann, Y. J., and Rudich, Y.: Examining feedbacks of aerosols to urban climate with a model that treats 3-D clouds with aerosol inclusions, J. Geophys. Res., 112, D24205, doi:10.1029/2007JD008922, 2007a.

Jaecker-Voirol, A. and Mirabel, P.: Heteromolecular Nucleation in the Sulfuric Acid-Water System, Atmos. Environ., 23, 20332057, 1989.

Jauregui E. and Romales, E.: Urban effects on convective precipitation in Mexico city, Atmos. Environ., 30, 3383-3389, 1996.

Johnson, C. E., Collins, W. J., Stevenson, D. S., and Derwent, R. G.: Relative roles of climate and emissions changes on future tropospheric oxidant concentrations, J. Geophys. Res., 104, $18631-$ $18645,1999$.

Johnson, C. E., Stevenson, D. S., Collins, W. J., and Derwent, R. G.: Role of climate feedback on methane and ozone studied with a coupled Ocean-Atmosphere-Chemistry model, Geophys. Res. Lett., 28(9), 1723-1726, 2001.

Jöckel, P., Sander, R., Kerkweg, A., Tost, H., and Lelieveld, J.: Technical note: the modular earth submodel system (MESSy) - a new approach towards earth system modeling, Atmos. Chem. Phys., 5, 433-444, 2005, http://www.atmos-chem-phys.net/5/433/2005/.

Jöckel P., Tost, H., Pozzer, A., Brühl, C., Buchholz, J., Ganzeveld, L., Hoor, P., Kerkweg, A., Lawrence, M. G., Sander, R., Steil, B., Stiller, G., Tanarhte, M., Taraborrelli, D., van Aardenne, J., and Lelieveld, J.: The atmospheric chemistry general circulation model ECHAM5/MESSy1: consistent simulation of ozone from the surface to the mesosphere, Atmos. Chem. Phys., 6, 50675104, 2006, http://www.atmos-chem-phys.net/6/5067/2006/.

Joseph, J. H.: The effect of a desert aerosol on a model of the general circulation, Proc. Symp.: in: On Radiation in the Atmosphere, edited by: Bolle, H. J., Science Press, 487-492, 1976.

Jungclaus, J. H., Keenlyside, N., Botzet, M., Haak, H., Luo, J.J., Latif, M., Marotzke, J., Mikolajewicz, U., and Roeckner,E.: Ocean circulation and tropical variability in the coupled model ECHAM5/MPIOM., J. Climate, 19, 3952-3972, 2006.

Kaminski, J.: Multiscale Atmospheric Chemistry Modelling with GEM-AQ, presentation at the COST-728 / NetFAM workshop on Integrated systems of meso-meteorological and chemical transport models, Copenhagen, Denmark, 21-23 May, 2007.

Kang, D., Eder, B. K., Stein, A. F., Grell, G. A., Peckham, S. E., and McHenry, J.: The New England Air Quality Forecasting Pi- lot Program: Development of an evaluation protocol and performance benchmark, J. Air Waste Manage. Assoc., 55, 1782-1796, 2005.

Katrlnak, K. A., Rez, P., and Buseck, P. R.: Structural variations in individual carbonaceous particles from an urban aerosol, Environ. Sci. Technol., 26, 1967-1976, 1992.

Katrlnak, K. A., Rez, P., Perkes, P. R., and Buseck, P. R.: Fractal geometry of carbonaceous aggregates from an urban aerosol, Environ. Sci. Technol., 27, 539-547, 1993.

Kaufman, Y. J. and Fraser, R. S.: The effect of smoke particles on clouds and climate forcing, Science, Washington, DC, 277(5332), 1636-1638, 12 September, 1997.

Kessler, E.: On the distribution and continuity of water substance in atmospheric circulation. Meteor. Monogr., No. 32, Amer. Meteor. Soc., 84 pp., 1969.

Khodri, M., Leclainche, Y., Ramstein, G., Braconnot, P., Marti, O., and Cortijo, E.: Simulating the amplification of orbital forcing by ocean feedbacks in the last glaciation, Nature, 410, 570-574, 2001.

Kiehl, J. T., Hack, J. J., Bonan, G. B., Boville, B. B., Williamson, D. L., and Rasch, P. J.: The National Center for Atmospheric Research Community Climate Model: CCM3, J. Climate, 11, 1131-1149, 1998.

Kiehl, J. T., Schneider, T. L., Rasch, P. J., Barth, M. C., and Wong, J.: Radiative forcing due to sulfate aerosols from simulations with the NCAR community climate model, version 3, J. Geophys. Res., 105, 1441-1457, 2000.

Kiehl, J. T. and Gent, P. R.: The Community Climate System Model, version 2, J. Climate, 17, 3666-3682, 2004.

Kinne, S., Lohmann, U., Feichter, J., Schulz, M., Timmreck, C., Ghan, S. J., Easter, R. C., Chin, M., Ginoux, P., Takemura, T., Tegen, I., Koch, D., Herzog, M., Penner, J., Pitari, G., Holben, B. N., Eck, T., Smirnov, A., Dubovik, O., Slutsker, I., Tanre, D., Torres, O., Mishchenko, M., Geogdzhayev, I., Chu, D. A., and Kaufman, Y. J.: Monthly averages of aerosol properties: A global comparison among models, satellite data and AERONET ground data, J. Geophys. Res., 108(D20), 4634, doi:10.1029/2001JD001253, 2003.

Kinne, S., Schulz, M., Textor, C., Guibert, S., Balkanski, Y., Bauer, S., Berntsen, T., Berglen, T., Boucher, O., Chin, M., Collins, W., Dentener, F., Diehl, T., Easter, R., Feichter, H., Fillmore, D., Ghan, S., Ginoux, P., Gong, S., Grini, A., Hendricks, J., Herzog, M., Horrowitz, L., Isaksen, I., Iversen, T., Kirkevåg, A., Kloster, S., Koch, D., Kristjánsson, J. E., Krol, M., Lauer, A., Lamarque, J. F., Lesins, G., Liu, X., Lohmann, U., Montanaro, V., Myhre, G., Penner, J., Pitari, G., Reddy, S., Seland, O., Stier, P., Takemura, T., and Tie, X.: An AeroCom initial assessment optical properties in aerosol component modules of global models, Atm. Chem. Phy., 6, 1815-1834, 2005.

Kim, D. and Stockwell, W. R.: An online-coupled meteorological and air quality modeling study of the effect of complex terrain on the regional transport and transformation of air pollutants over the Western United States, Atmos. Environ., 41, 2319-2334, 2007.

Knoth, O. and Wolke, R.: The online-coupled atmosphericchemistry aerosol model LMMUSCAT, presentation at the COST-728/NetFAM workshop on Integrated systems of mesometeorological and chemical transport models, Copenhagen, Denmark, 21-23 May, 2007. 
Koch, D., Jacob, D., Tegen, I., Rind, D., and Chin, M.: Tropospheric sulfur simulation and sulfate direct radiative forcing in the Goddard Institute for Space Studies general circulation model, J. Geophys. Res., 104, 23 799-23 822, 1999.

Korsholm, U., Baklanov, A., Mahura, A., Gross, A., Sørensen, J. H., Kaas, E., Chenevez, J., and Lindberg, K.: ENVIROHIRLAM: on-line integrated system, presentation at the COST728/NetFAM workshop on Integrated systems of meso-meteorological and chemical transport models, Copenhagen, Denmark, 21-23 May, 2007.

Kulmala, M., Laaksonen, A., and Pirjola, L.: Parameterizations for sulphric acid/water nucleation rates, J. Geophys. Res., 103, 8301-8308, 1998.

Lamarque, J.-F., Kiehl, J. T., Hess, P. G., Collins, W. D., Emmons, L. K., Ginoux, P., Luo, C., and Tie, X. X.: Response of a coupled chemistry-climate model to changes in aerosol emissions: Global impact on the hydrological cycle and the tropospheric burdens of $\mathrm{OH}$, ozone, and $\mathrm{NO}_{\mathrm{x}}$, Geophys. Res. Lett., 32, L16809, doi:10.1029/2005GL023419, 2005.

Langmann, B.: Numerical modelling of regional scale transport and photochemistry directly together with meteorological processes, Atmos. Environ. 34, 3585-3598, 2000.

Langmann, B.: A model study of the smoke-haze influence on clouds and warm precipitation formation in Indonesia 1997/1998, Atmos. Environ. 41, 6838-6852, doi:10.1016/j.atmosenv.2007.04.050, 2007.

Langmann, B., Varghese, S., Marmer, E., Vignati, E., Wilson, J., Stier, P., and O'Dowd, C.: Aerosol distribution over Europe: A model evaluation study with detailed aerosol microphysics, Atmos. Chem. Phys., 8, 1591-1607, 2008,

http://www.atmos-chem-phys.net/8/1591/2008/.

Kusik, C. L. and Meissner, H. P.: Electrolyte activity coefficients in inorganic processing, AIChE Symp. Series, 173, 14-20, 1978.

Langner, J., Bergstrom, R., and Foltescu, V.: Impact of climate change on surface ozone and deposition of sulphur and nitrogen in Europe, Atmos. Environ., 39, 1129-1141, 2005.

Levy, H. II, Mahiman, J. D., and Moxim, W. J.: Tropospheric ozone: the role of transport, J. Geophys. Res., 90(D2), 3753$3772,1985$.

Liao, H., Adams, P. J., Chung, S. H., Seinfeld, J. H., Mickley, L. J., and Jacob, D. J.: Interactions between tropospheric chemistry and aerosols in a unified general circulation model, J. Geophys. Res., 108(D1), 4001, doi:10.1029/2001JD001260, 2003.

Liao, H., Seinfeld, J. H., Adams, P. J., and Mickley, L. J.: Global radiative forcing of coupled tropospheric ozone and aerosols in a unified general circulation model, J. Geophys. Res., 109, D16207, doi:10.1029/2003JD004456, 2004.

Liao, H. and Seinfeld, J. H.: Global impacts of gas-phase chemistry-aerosol interactions on direct radiative forcing by anthropogenic aerosols and ozone, J. Geophys. Res., 110(D1), 8208, doi:10.1029/2005JD005907, 2005.

Liao, H., Chen, W.-T., and Seinfeld, J. H.: Role of climate change in global predictions of future tropospheric ozone and aerosols, J. Geophys. Res., 111, D12304, doi:10.1029/2005JD006852, 2006.

Lin, Y.-L., Farley, R. D., and Orville, H. D.: Bulk parameterization of the snow field in a cloud model, J. Climate Appl. Meteor., 22, 1065-1092, 1983.

Lohmann, U. and Feichter, J.: Impact of sulfate aerosols on albedo and lifetime of clouds: A sensitivity study with the ECHAM
GCM, J. Geophys. Res., 102, 12 685-13 700, 1997.

Lohmann, U., Feichter, J., Penner, J. E., and Leaitch, R.: Indirect effect of sulfate and carbonaceous aerosols: A mechanistic treatment, J. Geophys. Res., 105, 12 193-12 206, 2000.

Lohmann, U., Stier, P., Hoose, C., Ferrachat, S., Kloster, S., Roeckner, E., and Zhang, J.: Cloud microphysics and aerosol indirect effects in the global climate model ECHAM5-HAM, Atmos. Chem. Phys., 7, 3425-3446, 2007, http://www.atmos-chem-phys.net/7/3425/2007/.

Madronich, S.: Photodissociation in the atmosphere: 1. Actinic flux and the effects of ground reflections and clouds, J. Geophys. Res., 92, 9740-9752, 1987.

Malone, R. C., Auer, L. H., Glatzmaier, G. A., Wood, M. C., Toon, O. B.: Nuclear winter: three-dimensional simulations including interactive transport, scavenging, and solar heating of smoke, J. Geophys. Res., 91, 1039-1054, 1986.

Manins, P.: Integrated modelling systems in Australia, CSIRO, presentation at the COST-728 / NetFAM workshop on Integrated systems of meso-meteorological and chemical transport models, Copenhagen, Denmark, 21-23 May, 2007.

Manzini, E., Steil, B., Brühl, C., Giorgetta, M. A., and Krüger, K.: A new interactive chemistry-climate model: 2. Sensitivity of the middle atmosphere to ozone depletion and increase in greenhouse gases and implications for recent stratospheric cooling, J. Geophys. Res., 108(D14), 4429, doi:10.1029/2002JD002977, 2003.

Marchuk, G.I.: Matematicheskoe Modelirovanie v Probleme Okruzhayushchei Sredy (Mathematical modeling in the environmental problems), Izd. Nauka, Moscow, 1982, 319 pp., 1982.

Mathur, R., Xiu, A., Coats, C., Alapaty, K., Shankar, U., and Hanna, A.: Development of an Air Quality Modeling System with Integrated Meteorology, Chemistry, and Emissions, Proc. Measurement of Toxic and Related Air Pollutants, AWMA, Cary, NC, September, 1998.

Maurizi, A.: BOLCHEM, an integrated system for meteorology and atmospheric composition, presentation at the COST728/NetFAM workshop on Integrated systems of mesometeorological and chemical transport models, Copenhagen, Denmark, 21-23 May, 2007.

McKeen, S. A., Eder, B., Grell, G. A., McHenry, J., Stein, A., and Angevine, W. M.: Evaluation of prototype air quality forecast models - chemistry, NOAA/OAR report, 2003.

McKeen, S., Wilczak, J., Grell, G., Djalalova, I., Peckham, S., Hsie, E.-Y., Gong, W., Bouchet, V., Moffet, R., McHenry, J., McQueen, J., Tang, Y., Carmichael, G. R., Pagowski, M., Chan, A., Dye, T., Frost, G., Lee, P., and Mathur, R.: Assessment of an ensemble of seven real-time ozone forecasts over eastern North America during the summer of 2004, J. Geophys. Res., 110, D21307, doi:10.1029/2005JD005858, 2005.

McKeen, S., Chung, S. H., Wilczak, J., Grell, G., Djalalova, I., Peckham, S., Gong, W., Bouchet, V., Moffet, R., Tang, Y., Carmichael, G. R., Mathur, R., and Yu, S.: Evaluation of several $\mathrm{PM}_{2.5}$ forecast models using data collected during the ICARTT/NEAQS 2004 field study, J. Geophys. Res., 112, D10S20, doi:10.1029/2006JD007608, 2007.

McMurry, P. H. and Friedlander, S. K.: New particle formation in the presence of an aerosol, Atmos. Environ., 13, 1635-1651, 1979.

Menon, S., Del Genio, A. D., Koch, D., and Tselioudis, G.: GCM 
Simulations of the Aerosol Indirect Effect: Sensitivity to Cloud Parameterization and Aerosol Burden, J. Atmos. Sci., 59, 692713, 2002.

Mickley, L. J., Jacob, D. J., Field, B. D., and Rind, D.: Effects of future climate change on regional air pollution episodes in the United States, Geophys. Res. Let., 31, L24103, doi:10.1029/2004GL021216, 2004.

Mickley, L. J., Murti, P. P., Jacob, D. J., Logan, J. A., Koch, D. M., and Rind, D.: Radiative forcing from tropospheric ozone calculated with a unified chemistry-climate model, J. Geophys. Res., 104(D23), 30 153-30 172, doi:10.1029/1999JD900439, 1999.

Mishchenko, M. I., Rossow, W. B., Macke, A., and Lacis, A. A.: Sensitivity of cirrus cloud albedo, bidirectional reflectance and optical thickness retrieval accuracy to ice particle shape, J. Geophys. Res., 101(D12), 16973-16986, doi:10.1029/96JD01155, 1996.

Mlawer, E. J., Taubman, S. J., Brown, P. D., Iacono, M. J., and Clough, S. A.: Radiative transfer for inhomogeneous atmosphere: RRTM, a validated correlated-k model for the longwave, J. Geophys. Res., 102(D14), 16663-16682, 1997.

Mahowald, N. M., Lamarque, J.-F., Tie, X. X., and Wolff, E.: Seasalt aerosol response to climate change: Last Glacial Maximum, preindustrial, and doubled carbon dioxide climates, J. Geophys. Res., 111, D05303, doi:10.1029/2005JD006459, 2006 a.

Mahowald N. M., Muhs, D. R., Levis, S., Rasch, P. J., Yoshioka, M., Zender, C. S., Luo, C.: Change in atmospheric mineral aerosols in response to climate: Last glacial period, preindustrial, modern, and doubled carbon dioxide climates, J. Geophys. Res., 111, D10202, doi:10.1029/2005JD006653, 2006b.

Nagashima, T., Takahashi, M., Takigawa, M., and Akiyoshi, H.: Future development of the ozone layer calculated by a general circulation model with fully interactive chemistry, Geophys. Res. Lett., 29(8), 1162, doi:10.1029/2001GL014026, 2002.

Napari, I., Noppel, M., Vehkamäki, H., and Kulmala, M.: Parameterization of ternary nucleation rates for $\mathrm{H}_{2} \mathrm{SO}_{4}-\mathrm{NH}_{3}-\mathrm{H}_{2} \mathrm{O}$ vapors, J. Geophys. Res., 107, 4381, doi:10.1029/2002JD002132, 2002.

Neelin, J. D. and Zeng, N.: The first quasi-equilibrium tropical circulation model-Formulation, J. Atmos. Sci., 57, 1741-1766, 2000.

Nenes, A., Pandis, S. N., and Pilinis, C.: ISORROPIA: A new thermodynamic equilibrium model for multiphase multicomponent inorganic aerosols, Aquat. Geochem., 4, 123-152, 1998.

Ng, N. L., Kroll, J. H., Chan, A. W. H., Chhabra, P. S., Flagan, R. C., and Seinfeld, J. H.: Secondary organic aerosol formation from m-xylene, toluene, and benzene, Atmos. Chem. Phys., 7, 3909-3922, 2007,

http://www.atmos-chem-phys.net/7/3909/2007/.

Ng, N. L., Chhabra, P. S., Chan, A. W. H., Surratt, J. D., Kroll, J. H., Kwan, A. J., McCabe, D. C., Wennberg, P. O., Sorooshian, A., Murphy, S. M., Dalleska, N. F., Flagan, R. C., and Seinfeld, J. H.: Effect of $\mathrm{NO}_{\mathrm{x}}$ level on secondary organic aerosol (SOA) formation from the photooxidation of terpenes, Atmos. Chem. Phys., 7, 5159-5174, 2007, http://www.atmos-chem-phys.net/7/5159/2007/.

Noppel, M., Vehkamäki, H., and Kulmala, M.: An improved model for hydrate formation in sulfuric acid-water nucleation, J. Chem. Phys., 116, 218-228, 2002.

Odum, J. R., Jungkamp, T. P. W., Griffin, R. J., Forstner, H. J. L.,
Flagan, R. C., and Seinfeld, J. H.: Aromatics, reformulated gasoline, and atmospheric organic aerosol formation, Environ. Sci. Technol., 31, 1890-1897, 1997.

O'Connor, F., Mann, G., Morgenstern, O., Carslaw, K., Johnson, C., Pyle, J., Bellouin, N., Bushell, A., Carver, G., Osprey , S., Rae, J., Sanderson, M., and Young, P.: Report on chemistry and aerosols modeling in UKCA, UACK project, May 2006, http://www.ukca.ac.uk, 2006.

Pagowski, M., Grell, G. A., Devenyi, D., Peckham, S. E., McKeen, S. A., Gong, W., Delle Monache, L., McHenry, J. H., McQueen, J., and Lee, P.: Application of dynamic linear regression to improve the skill of ensemble-based deterministic ozone forecasts, Atmos. Environ., 40, 3240-3250, 2006.

Pan, Y., Hu, X.-M., and Zhang, Y.: Sensitivity of gaseous and aerosol predictions to gas-phase chemical mechanisms, presentation at the 10th Conference on Atmospheric Chemistry, New Orleans, Louisiana, 20-24 January, 2008.

Pandis, S. N., Harley, R. A., Cass, G. R., and Seinfeld, J. H.: Secondary organic aerosol formation and transport, Atmos. Environ., 26A, 2269-2282, 1992.

Penenko, V. V., Aloyan, A. E., Bazhin, N. M., and Skubnevskaya, G. I.: Chislennaya Model' Gidrometeorologicheskogo Rezhima I Zagryazneniya Atmosfery Gorodov I Promyshlennykh Rayonoa (A Mathematical Model of Hydrometeorological Conditions and Pollution of The Atmospheric of Cities and Industrial Regions), Meteorologiya i Gidroloqiya, Moscow, 4, 5-15, 1984.

Penenko, V. V. and Aloyan, A. E.: Modeli I Metody dlya Zadach Okhrany Okruzhayushchei Sredy (Models and methods for environment protection problems), Nauka, Novosibirsk, 256 pp. (in Russian), 1985.

Pankow, J. F.: An absorption model of gas-particle partitioning of organic compounds in the atmosphere, Atmos. Environ., 28, 185-188, 1994a.

Pankow, J. F.: An absorption model of the gas/aerosol partitioning involved in the formation of secondary organic aerosol, Atmos. Environ., 28, 189-193, 1994b.

Penner, J. E.: Comment on "Control of fossil\&hyphen;fuel particulate black carbon and organic matter, possibly the most effective method of slowing global warming" by Jacobson, M. Z., J. Geophys. Res., 108(D24), 4771, doi:10.1029/2002JD003364, 2003.

Penner, J. E., Zhang, S. Y., and Chuang, C. C.: Soot and smoke aerosol may not warm climate, J. Geophys. Res., 108(D21), 4657, doi:10.1029/2003JD003409, 2003.

Pitari, G., Palermi, S., Visconti, G., and Prinn, R. G.: Ozone Response to a $\mathrm{CO}_{2}$ Doubling: Results From a stratospheric circulation model with heterogeneous chemistry, J. Geophys. Res., 97(D5), 5953-5962, doi:10.1029/92JD00164, 1992.

Pitari, G., Mancini, E., Rizi, V., and Shindell, D.: Impact of future climates and emission changes on stratospheric aerosol and climate, J. Atmos. Sci., 59, 414-440, 2002.

Pósfai, M., Anderson, J. R., Buseck, P. R., and Sievering, H.: Soot and sulfate aerosol particles in the remote marine troposphere, J. Geophys. Res., 104, 21 685-21 693, 1999.

Prather, M., Gauss, M., Berntsen, T., Isaksen, I., Sundet, J., Bey, I., Brasseur, G., Dentener, F., Derwent, R., Stevenson, D., Grenfell, L., Hauglustaine, D., Horowitz, L., Jacob, D., Mickley, L., Lawrence, M., von Kuhlmann, R., Muller, J.-F., Pitari, G., Rogers, H., Johnson, M., Pyle, J., Law, K., van Weele, M., and Wild, O.: Fresh air in the 21 st century?, Geophys. Res. Lett., 
30(2), 1100, doi:10.1029/2002GL016285, 2003.

Prinn, R., Jacoby, H., Sokolov, A., Wang, C., Xiao, X., Yang, Z., Eckhaus, R., Stone, P., Ellerman, D., Melillo, J., Fitzmaurice, J., Kicklighter, D., Holian, G., and Liu, Y.: Integrated global system model for climate policy assessment feedbacks and sensitivity studies, Climatic Change, 41, 469-546, 1999.

Pun, B.: Development and initial application of the sesqui-version of MADRID, J. Geophys. Res., in press, 2008.

Pun, B. K., Griffin, R. J., Seigneur, C., and Seinfeld, J. H.: Secondary organic aerosol: 2. Thermodynamic model for gas/particle partitioning of molecular constituents, J. Geophys. Res., 107(D17), 4333, doi:10.1029/2001JD000542, 2002.

Pun, B., Seigneur, C., and Lohman, K.: Modeling secondary organic aerosol formation via multiphase partitioning with molecular data, Environ. Sci. Technol., 40, 4722-4731, 2006.

Qian, Y. and Giorgi, F.: Interactive coupling of regional climate and sulfate aerosol models over eastern Asia, J. Geophys. Res., 104(D6), 6477-6500, doi:10.1029/98JD02347, 1999.

Qian, Y., Giorgi, F., Huang, Y., Chameides, W., and Luo, C.: Regional simulation of anthropogenic sulfur over East Asia and its sensitivity to model parameters, Tellus, 53B, 171-191, 2001.

Rasch, P. J. and Kristjánsson, J. E.: A comparison of the CCM3 model climate using diagnosed and predicted condensate parameterizations. J. Climate, 11, 1587-1614, 1998.

Rasch, P. J., Barth, M. C., Kiehl, J. T., Schwartz, S. E., and Benkovitz, C. M.: A description of the global sulfur cycle and its controlling processes in the National Center for Atmospheric Research Community Climate Model Version 3, J. Geophys. Res., 105, 1367-1385, 2000a.

Rasch, P. J., Boville, B. A., and Brasseur, G. P.: A threedimensional general circulation model with coupled chemistry for the middle atmosphere, J. Geophys. Res., 100(D5), 90419072, doi:10.1029/95JD00019, 1995.

Rasch, P. J., Coleman, D. B., Mahowald, N., Williamson, D. L., Lin, S.-J., Boville, B. A., and Hess, P.: Characteristics of atmospheric transport using three numerical formulations for atmospheric dynamics in a single GCM framework, J. Climate, 19, 2243-2266, 2006a.

Rasch, P. J., Stevens, M. J., Ricciardulli, L., Dai, A., Negri, A., Wood, R., Boville, B. A., Eaton, B., and Hack, J. J.: Characterization of tropical transient activity in the CAM3 atmospheric hydrologic cycle, J. Climate, 19, 2222-2242, 2006 b.

Roelofs, G.-J. and Lelieveld, J.: Distribution and budget of $\mathrm{O}_{3}$ in the troposphere calculated with a chemistry general circulation model, J. Geophys. Res., 100(D10), 20 983-20 998, 1995.

Roelofs, G.-J., Lelieveld, J., and Ganzeveld, L.: Simulation of global sulfate distribution and the influence of effective cloud drop radii with a coupled photochemistry-sulfur cycle model, Tellus, Ser. B, 50, 224-242, 1998.

Rose, K. and Brasseur, G.: A three-dimensional model of chemically active trace species in the middle atmosphere during disturbed winter conditions, J. Geophys. Res., 94(D13), 1638716403, doi:10.1029/89JD01092, 1989.

Rosenfeld, D.: TRMM Observed First Direct Evidence of Smoke from Forest Fires Inhibiting Rainfall, Geophys. Res. Lett., 26(20), 3105-3108, 1999.

Rosenfeld, D.: Suppression of Rain and Snow by Urban and Industrial Air Pollution, Science, 287(5459), 1793-1796, 2000.

Rosenfeld, D. and Lensky, I. M.: Spaceboren sensed insights into precipitation formation processes in continental and maritime clouds, B. Am. Meteorol. Soc., 79, 2457-2476, 1998.

Rosenfeld, D. and Woodley, W. L.: Satellite-inferred impact of aerosols on the microstructure of Thai convective clouds. Processings, Seven WMO Scientific Conference on Weather Modification, Chiang Mai, Thailand, 17-22 February 1999, 17-20, 1999.

Rozanov, E. V., Schlesinger, M. E., and Zubov, V. A.: The University of Illinois, Urbana-Champaign three-dimensional stratosphere-troposphere general circulation model with interactive ozone photochemistry: Fifteen-year control run climatology, J. Geophys. Res., 106(D21), 2723327254, doi:10.1029/2000JD000058, 2001.

Sanderson, M. G., Collins, W. J., Johnson, C. E., and Derwent, R. G.: Present and future acid deposition to ecosystems: The effect of climate change, Atmos. Environ., 40, 1275-1283, 2006.

Sarwar, G., Luecken, D., Yarwood, G., Whitten, G. Z., and Carter, W. P. L.: Implementing an updated carbon bond mechanism into the community multiscale air quality model, presentation at the 2005 Models-3 Workshop, 26-28 September, Chapel Hill, NC., 2005.

Sarwar, G., Luecken, D., Yarwood, G., Whitten, G. Z., and Carter, W. P. L.: Impact of an updated carbon bond mechanism on predictions from the community multiscale air quality model, J. Appl. Meteorol., in press, 2008.

Schell, B., Ackermann, I. J., Hass, H., Binkowski, F. S., and Ebel, A.: Modeling the formation of secondary organic aerosol within a comprehensive air quality model system, J. Geophys. Res., 106, 28 275-28 293, 2001.

Schlesimger, M. E. and Mintz, Y.: Numerical simulation of ozone production, transport and distribution with a global atmospheric general circulation model, J. Atmos. Sci., 36, 1325-1361, 1979.

Schnadt, C., Dameris, M., Ponater, M., Hein, R., Grewe, V., and Steil, B.: Interaction of atmospheric chemistry and climate and its impact on stratospheric ozone, Clim. Dynam., 18, 501-517, 2002.

Seaman, N. L.: Meteorological modeling for air-quality assessments, Atmos. Environ., 34, 2231-2259, 2000.

Seigneur, C. S.: Air pollution: current challenges and future opportunities, AIChE Journal, February, 51(2), 356-364, 2005.

Seinfeld, J. H.: Air Pollution: A Half Century of Progress, AIChE Journal, June, 50(6), 1096-1108, 2004.

Shindell, D. T., Rind, D., and Lonergan, P.: Increased polar stratospheric ozone losses and delayed eventual recovery owing to increasing greenhouse-gas concentrations, Nature, 392, 589-592, doi:10.1038/33385, 1998.

Shindell, D. T., Lee Grenfell, J., Rind, D., Grewe, V., and Price, C.: Chemistry-climate interactions in the Goddard Institute for Space Studies general circulation model, 1, Tropospheric chemistry model description and evaluation, J. Geophys. Res., 106(D8), 8047-8076, doi:10.1029/2000JD900704, 2001.

Skamarock, W. C., Klemp, J. B., Dudhia, J., Gill, D. O., Barker, D. M., Wang, W., and Powers, J. G.: A description of the advanced research WRF version 2, NCAR Technical Note, NCAR/TN468+STR, 88 pp., http://wrf-model.org/ wrfadmin/publications.php, 2005.

Sofiev, M.: Aerosol species in the AQ forecasting system of FMI: possibilities for coupling with NWP models, presentation at the COST-728/NetFAM workshop on Integrated systems of meso- 
meteorological and chemical transport models, Copenhagen, Denmark, 21-23 May, 2007.

Steil, B., Bruhl, C., Manzini, E., Crutzen, P. J., Lelieveld, J., Rasch, P. J., Roeckner, E., and Kruger, K.: A new interactive chemistry-climate model: 1 . Present-day climatology and interannual variability of the middle atmosphere using the model and 9 years of HALOE/UARS data, J. Geophys. Res., 108(D9), 4290, doi:10.1029/2002JD002971, 2003.

Stier, P., Feichter, J., Kinne, S., Kloster, S., Vignati, E.,Wilson, J., Ganzeveld, L., Tegen, I., Werner, M., Balkanski, Y., Schulz, M., Boucher, O., Minikin, A., and Petzold, A.: The aerosolclimate model ECHAM5-HAM, Atmos. Chem. Phys., 5, 11251156, 2005, http://www.atmos-chem-phys.net/5/1125/2005/.

Stier, P., Seinfeld, J. H., Kinne, S., and Boucher O.: Aerosol absorption and radiative forcing, Atmos. Chem. Phys., 7, 5237-5261, 2007

Stockwell, W. R., Kirchner, F., Kuhn, M., and Seefeld, S.: A new mechanism for regional atmispheric chemistry modeling, J. Geophys. Res., 102, 25 847-25 879, 1997.

Stockwell, W. R., Middleton, P., Chang, J. S., and Tang, X.: The second generation regional acid deposition model chemical mechanism for regional air quality modeling, J. Geophys. Res., 95, 16343-16367, 1990.

Stokes, R. H. and Robinson, R. A.: Interactions in aqueous nonelectrolyte solutions, I, Solute-solvent equilibria, J. Phys. Chem., 70, 2126-2130, 1966.

Taghavi, M., Cautenet, S., and Foret, G.: Simulation of ozone production in a complex circulation region using nested grids, Atmo. Chem. Phys., 4, 825-838, 2004.

Takigawa, M., Takahashi, M., and Akiyoshi, H.: Simulation of ozone and other chemical species using a Center for Climate Systems Research/National Institute for Environmental Studies atmospheric GCM with coupled stratospheric chemistry, J. Geophys. Res., 104, 14 003-14 018, 1999.

Taylor, K. E. and Penner, J. E.: Response of the climate system to atmospheric aerosols and greenhouse gases, Nature, 369, 734 737, doi:10.1038/369734a0, 1994.

Textor, C., Schulz, M., Guibert, S., Kinne, S., Balkanski, Y., Bauer, S., Berntsen, T., Berglen, T., Boucher, O., Chin, M., Dentener, F., Diehl, T., Easter, R., Feichter, H., Fillmore, D., Ghan, S., Ginoux, P., Gong, S., Grini, A., Hendricks, J., Horrowitz, L., Isaksen, I., Iversen, T., Kirkevåg, A., Kloster, S., Koch, D., Kristjánsson, J. E., Krol, M., Lauer, A., Lamarque, J. F., Liu, X., Montanaro, V., Myhre, G., Penner,J., Pitari, G., Reddy, S., Seland, O., Stier, P., Takemura, T., and Tie, X.: Analysis and quantification of the diversities of aerosol life cycles within AeroCom, Atm. Chem. Phy., 6, 1777-1813, 2006.

Thompson, S. L.: Global interactive transport simulations of nuclear war smoke, Nature, 317, 35-39, 1985.

Tie, X., Madronich, S., Walters, S., Edwards,D. P., Ginoux, P., Mahowald, N., Zhang, R., Lou, C., and Brasseur, G.: Assessment of the global impact of aerosols on tropospheric oxidants, J. Geophys. Res., 110, D03204, doi:10.1029/2004JD005359, 2005.

Tie, X.-X., Madronich, S., Li, G.-H., Ying, Z.-M., Zhang, R., Garcia, A. R., Lee-Taylor, J., and Liu, Y.-B.: Characterizations of chemical oxidants in Mexico City: A regional chemical dynamical model (WRF/Chem) study, Atmos. Environ., 41, 1989-2008, 2007.
Tulet, P., Crassier, V., Cousin, F., Suhre, K., and Rosset, R.: ORILAM, a three-moment lognormal aerosol scheme for mesoscale atmospheric model: Online coupling into the Meso$\mathrm{NH}-\mathrm{C}$ model and validation on the escompte campaign, J. Geophys. Res., 110, D18201, doi:10.1029/2004JD005716, 2005.

Tulet P., Crassier, V., Solmon, F., Guedalia, D., and Rosset, R.: Description of the Mesoscale Non Hydrostatic Chemistry model and application to a transboundary pollution episode between northern France and southern England, J. Geophys. Res., 108, 4021, doi.10.1029/2000JD000301, 2003.

Tulet, P., Grini, A., Griffin, R. J., and Petitcol, S.: ORILAM-SOA: A computationally efficient model for predicting secondary organic aerosols in three-dimensional atmospheric models, J. Geophys. Res., 111, D23208, doi:10.1029/2006JD007152, 2006.

Uno, I., Amano, H., Emori, S., Kinoshita, K., Matsui, I., and Sugimoto, N.: Trans-Pacific yellow sand transport observed in April 1998: A numerical simulation, J. Geophys. Res., 106(D16), 18 331-18 344, doi:10.1029/2000JD900748, 2001.

Uno I., Carmichael, G. R., Streets, D. G., Tang, Y., Yienger, J. J., Satake, S., Wang, Z., Woo, J.-H., Guttikunda, S., Uematsu, M., Matsumoto, K., Tanimoto, H., Yoshioka, K., and Iida, T.: Regional chemical weather forecasting system CFORS: Model descriptions and analysis of surface observations at Japanese island stations during the ACE-Asia experiment, J. Geophys. Res., 108(D23), 8668, doi:10.1029/2002JD002845, 2003.

Vehkamäki, H., Kulmala, M., Napari, I., Lehtinen, K. E. J., Timmreck, C., Noppel, M., and Laaksonen, A.: An improved parameterization for sulfuric acid-water nucleation rates for tropospheric and stratospheric conditions, J. Geophys. Res., 107, 4622, doi:10.1029/2002JD002184, 2002.

Vogel, B., Hoose, C., Vogel, H., and Kottmeier, Ch.: A model of dust transport applied to the Dead Sea area, Meteorol. Z., 14, 611-624, 2006.

Vogel, H.: LM-ART-aerosols and reactive trace gases within LM, presentation at the COST728/NetFAM workshop on Integrated systems of meso-meteorological and chemical transport models, Copenhagen, Denmark, 21-23 May, 2007.

Warner, J.: A reduction in rainfall associated with smoke from sugar cane fires - an inadvertent weather modification?, J. Appl. Meteor., 7, 247-251, 1968.

Washington, W. M.: Documentation for the Community Climate Model (CCM), Version 0. Tech. Rep., National Center for Atmospheric Research, Boulder, CO, 222pp., 1982.

Wexler, A. S., Lurmann, F. W., and Seinfeld, J. H.: Modeling Urban and Regional Aerosols, I. Model Development, Atmos. Environ. 28, 531-546, 1994

Wild, O., Zhu, X., and Prather, M. J.: Fast-J: Accurate simulation of in- and below cloud photolysis in tropospheric chemical models, J. Atmos. Chem., 37, 245-282, 2000.

Williamson, D. L., Kiehl, J. T., Ramanathan, V., Dickinson, R. E., and Hack, J. J.: Description of NCAR Community Climate Model (CCM1). Tech. Rep. NCAR/TN-285_STR, National Center for Atmospheric Research, Boulder, CO, 112 pp., 1987.

Wolke, R., Hellmuth, O., Knoth, O., Schröder, W., Heinrich, B., and Renner, E.: The chemistry-transport modeling system LMMUSCAT: Description and CITYDELTA applications. Proceedings of the 26th International Technical Meeting on Air Pollution and Its Application, Istanbul, May 2003, 369-379, 2003.

Wong, S., Wang, W.-C., Isaksen, I. S. A., Berntsen, T. K., and Sun- 
det, J. K.: A global climate-chemistry model study of presentday tropospheric chemistry and radiative forcing from changes in tropospheric $\mathrm{O}_{3}$ since the reindustrial period, J. Geophys. Res., 109, D11309, doi:10.1029/2003JD003998, 2004.

Xiu, A., Mathur, R., and Coats, C.: On the development and testing of an air quality modeling system with integrated meteorology, chemistry, and emissions, Proceedings, Symposium on Interdisciplinary Issues in Atmospheric Chemistry, Dallas, TX, American Meteorology Society, 117-120, 1999.

Yarwood, G., Rao, S., and Yocke, M.: Updates to the carbon bond chemical mechanism: CB05, Final Report prepared for the U.S. Environmental Protection Agency, RT-04-00675, ENVIRON International Corporation, Novato, CA 94945, 2005.

Zaveri, R. A.: Development and evaluation of a comprehensive tropospheric chemistry model for regional and global applications, Ph.D. thesis, Va. Polytech. Inst. and State Univ., Blacksburg, Va., 1997.

Zaveri, R. A. and Peters, L. K.: A new lumped structure photochemical mechanism for large-scale applications, J. Geophys. Res., 104, 30 387-30 415, 1999.

Zaveri, R. A., Easter, R. C., and Peters, L. K.: A computationally efficient Multicomponent Equilibrium Solver for Aerosols (MESA), J. Geophys. Res., 110, D24203, doi:10.1029/2004JD005618, 2005a.

Zaveri, R. A., Easter, R. C., and Wexler, A. S.: A new method for multicomponent activity coefficients of electrolytes in aqueous atmospheric aerosols, J. Geophys. Res., 110, D02201, doi:10.1029/2004JD004681, 2005b.

Zaveri, R. A., Easter, R. C., Fast, J. D., and Peters, L. K.: Model for Simulating Aerosol Interactions and Chemistry (MOSAIC), J. Geophys. Res., doi:10.1029/2007jd008782, in press, 2008, in press, 2008.

Zdanovskii, A. B.: New methods of calculating solubilities of electrolytes in multicomponent systems, Z. Fiz. Khim, 22, 14751485, 1948.

Zhang, Y., Pun, B., Vijayaraghavan, K., Wu, S.-Y., Seigneur, C., Pandis, S., Jacobson, M., Nenes, A., and Seinfeld, J. H.: Development and application of the model for aerosol dynamics, reaction, ionization and dissolution (MADRID), J. Geophys. Res., 109, D01202, doi:10.1029/2003JD003501, 2004.

Zhang, Y., Seigneur, C., Seinfeld, J. H., Jacobson, M. Z., and Binkowski, F. S.: Simulation of aerosol dynamics: A comparative review of algorithms used in air quality models, Aerosol Sci. Technol., 31, 487-514, 1999.

Zhang, Y., Seigneur, C., Seinfeld, J. H., Jacobson, M., Clegg,
S. L., and Binkowski, F. S.: A Comparative Review of Inorganic Aerosol Thermodynamic Equilibrium Modules: Similarities, Differences, and Their Likely Causes, Atmos. Environ., 34, 117-137, 2000.

Zhang, Y., Easter, R. C., Ghan, S. J., and Abdul-Razzak, H.: Impact of aerosol size representation on modeling aerosol-cloud interactions, J. Geophys. Res., 107, 4558, doi:10.1029/2001JD001549, 2002.

Zhang, Y., Hu, X.-M., Howell, G. W., Sills, E., Fast, J. D., Gustafson Jr., W. I., Zaveri, R. A., Grell, G. A., Peckham, S. E., and McKeen, S. A.: Modeling Atmospheric Aerosols in WRF/CHEM, oral presentation at the 2005 Joint WRF/MM5 User's Workshop, 27-30 June, Boulder, CO, 2005a.

Zhang, Y., Hu, X.-M., Wang, K., Huang, J.-P., Fast, J. D., Gustafson Jr., W. I., Chu, D. A., and Jang, C.: Evaluation of WRF/ChemMADRID with Satellite and Surface Measurements: Chemical and Optical Properties of Aerosols, oral presentation at the 2005 AGU Fall Meeting, 5-9 December 2005, San Francisco, CA, USA, 2005c.

Zhang, Y. and Jacobson, M.Z.: Implementation and Testing of EQUISOLV II in the CMAQ Modeling System, oral presentation at the 2005 Models-3 Workshop, 26-28 September, Chapel Hill, NC, 2005a.

Zhang, Y. and Jacobson, M.Z.: A Comparative Study of Nucleation Parameterizations for 3-D Atmospheric Models, oral presentation at the $9^{\text {th }}$ Atmospheric Sciences and Air Quality Conference (ASAAQ2005), 27-29 April, San Francisco, CA, 2005b.

Zhang, Y., Hu, X.-M., Wen, X.-Y., Schere, K. L., and Jang, C. J.: Simulating Climate-Chemistry-Aerosol-Cloud-Radiation Feedbacks in WRF/Chem: Model Development and Initial Application, oral presentation at the 6th Annual CMAS Models-3 User's Conference, 1-3 October 2007, Chapel Hill, NC, 2007a.

Zhang, Y., Huang, J.-P., Henze, D. K., and Seinfeld, J. H.: Role of isoprene in secondary organic aerosol formation on a regional scale, J. Geophys. Res., 112, D20207, doi:10.1029/2007JD008675, 2007b.

Zhang, Y., Wen, X.-Y., Hu, X.-M., and Jang, C. J.: Simulating the Effect of Aerosols on Regional Climate Using WRF/Chem, oral presentation at the 10th Conference on Atmospheric Chemistry, New Orleans, Louisiana, 20-24 January, 2008a.

Zhang, Y., Wen, X.-Y., Skamarock, W. C., Grell, G. A., Peckham, S. E., Ghan, S. J., and Easter, R. C.: Some Preliminary Results from the Development of Global WRF/Chem, oral presented the 10th Conference on Atmospheric Chemistry, New Orleans, Louisiana, 20-24 January, 2008b. 